\title{
ADDENDUM TO THE CORRECTIVE ACTION PLAN FOR UNDERGROUND STORAGE TANKS 1219-U, 1222-U, 2082-U, 2068-U AT THE RUST GARAGE FACILITY, BUILDINGS 9720-15 AND 9754-1
}

\author{
OAK RIDGE Y-12 PLANT \\ OAK RIDGE, TENNESSEE \\ FACILITY ID \#0-010117
}

\section{January 1994}

Environmental Management Department

Health, Safety, Environment, and Accountability Organization

\author{
Prepared by \\ Science Applications International Corporation \\ Under Subcontract 18B-99069C \\ for the \\ Oak Ridge Y-12 Plant \\ Oak Ridge, Tennessee 37831 \\ Managed by \\ Martin Marietta Energy Systems, Inc. \\ for the \\ U.S. Department of Energy \\ Under Contract No. DE-AC05-84OR21400
}


TABLE OF CONTENTS

Page

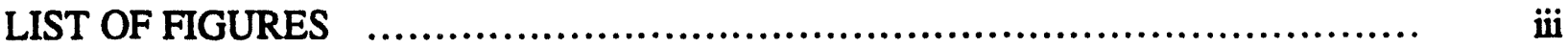

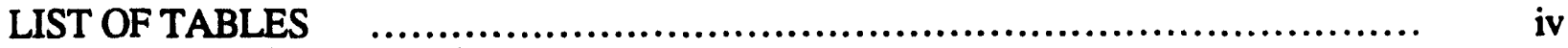

LIST OF ACRONYMS............................................................... v

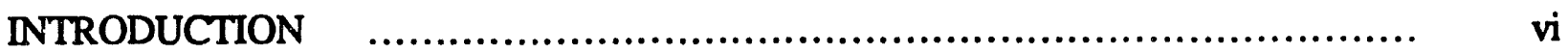

CORRECTIVE ACTION PLAN

7.0 CORRECTIVE ACTIONS CONSIDERED........................................... $7-1$

7.1 Identification of Potential Corrective Action Options ...................... 7-1

7.1.1 Corrective Action Objectives............................................ 7-1

7.1.2 General Response Actions .................................. 7-1

7.1.2.1 No Action/Institutional Actions......................... 7-1

7.1.2.2 Containment Actions ...................................... $7-2$

7.1.2.3 Removal/Extraction Actions....................... 7-2

7.1.2.4 Collection/Control Actions ........................ 7-2

7.1.2.5 Treatment Actions ................................ 7-2

7.1.2.6 Storage/Disposal/Discharge Actions..................... 7-3

7.1.3 Initial Screening Criteria.............................................. 7-3

7.1.4 Initial Screening of Technologies and Process Options ........... 7-4

7.1.4.1 No Action/nstitutional Actions ........................ 7-4

7.1.4.2 Containment Actions ................................... 7-4

7.1.4.3 Removal/Extraction Actions............................. 7-12

7.1.4.4 Collection/Control Actions .......................... 7-12

7.1.4.5 Treatment Actions ................................ 7-12

7.1.4.6 Disposal....................................... 7-14

7.1.5 Development of Corrective Action Options ..................... 7-14

7.1.5.1 Removal/Extraction................................. 7-15

7.1.5.2 Treatment (Thermal, Physical, and Biological)...... 7-15

7.1.5.3 Disposal (Onsite or Offsite) ......................... 7-15

7.1.5.4 Potential Corrective Action Options ................... 7-16

7.2 Selection of Corrective Actions........................................ $7-16$

7.2.1 Evaluation Criteria ................................................... $7-19$

7.2.1.1 Effectiveness................................................. $7-19$

7.2.1.2 Implementability ................................ $7-19$

7.2.1.3 Cost ........................................ $7-19$

7.2.2 Evaluation of Corrective Actions.................................. 7-19

7.2.2.1 Removal/Extraction................................ $7-19$

7.2.2.2 Thermal Treatment (Incineration) .................. 7-20

7.2.2.3 Thermal Treatment (Thermal Desorption) ............. 7-21

7.2.2.4 Physical Treatment (Soil Washing)...................... 7-21

7.2.2.5 Biological Treatment (Solid Phase Bioremediation).. 7-21

7.2.2.6 Disposal (Onsite/Offsite)................................ 7-22

7.2.3 Summary of Top Three Selected Corrective Action Options...... 7-22

7.2.3.1 Advantages and Disadvantages ...................... 7-22

7.2.3.2 Projected Remediation Periods.......................... 7-27 


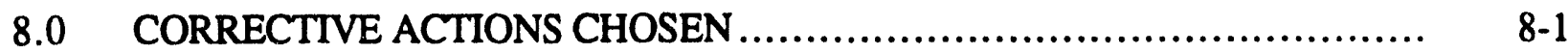

8.1 Soil Corrective Action .............................................. 8-1

8.1.1 General Description of Soil Corrective Action....................... 8-1

8.1.2 Soil Remediation System Analysis................................... 8-1

8.1.2.1 Soil Removal.................................... 8-1

8.1.2.2 Soil Treatment....................................... 8-8

8.1.2.3 Soil Disposal ..................................... 8-11

8.2 Groundwater Corrective Action ........................................ 8-12

8.2.1 Corrective Actions Considered ............................. 8-12

8.2.2 General Description of Groundwater Corrective Action............ 8-13

8.2.3 Description of the S-3 Ponds ................................. 8-13

8.2.4 Nature and Extent of Groundwater Contamination ................. 8-15

8.2.5 Integration of UST and CERCLA Requirements................... 8-19

9.0 PROPOSED IMPLEMENTATION SCHEDULE...................................... $9-1$

9.1 Soil Corrective Action Schedule....................................... 9-1

9.2 Ground water Corrective Action Schedule................................

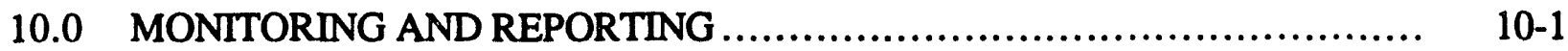

10.1 Soil Corrective Action ................................................ 10-1

10.1.1 Monthly and Quarterly Reports................................... 10-1

10.1.2 Corrective Action Report...................................... 10-1

10.2 Groundwater Corrective Action .......................................... 10-1

APPENDIX A CERCLA SCHEDULE FOR Y-12 PLANT GROUNDWATER

OPERABLE UNIT (OU1) ….................................... A-1 


\section{LIST OF FIGURES}

Page

\section{Eigure Title}

8-1 Soil Treatment Process Flow ..................................... $\quad 8$-2

8-2 Rust Garage Facility Horizontal Zone of Influence Map ................. 8-4

8-3 Rust Garage Facility Vertical Zone of Influence Map.................... 8-6

8-4 Components of the S-3 Ponds Waste Management Area.................. 8-14

8-5 Location of Groundwater Monitoring Wells at the Rust Garage Facility... 8-17 


\section{LIST OF TABLES}

Page

Table Title

7-1 Initial Screening of Technologies and Process Options for Rust Garage Facility Soil Remediation ............................... $\quad 7.5$

7-2 Evaluation of the Selected Process Options for Soil Remediation at the Rust Garage Facility ........................................... $\quad 7-17$

7-3 Technology Specific Requirements of Top Three Corrective Action Options

7-4 Advantages and Disadvantages of Top Three Corrective Action Options

7-5 Projected Remediation Periods of Top Three Corrective Action Options

8-1 Volume Calculation for Contaminated and Noncontaminated Soil at the Rust Garage Facility Based on Average End Area Method

8-2 Analytical Methods Proposed for Analyses of Remediation Soil Samples Collected at the Rust Garage Facility.

8-3 Summary of S-3 Ponds Groundwater Quality Results Derived from 1992 Quarterly Groundwater Sampling at the Y-12 Plant.............................

8-4 Summary of Rust Garage Facility Groundwater Quality Results Derived from 1993 Quarterly Groundwater Sampling at the Y-12 Plant. 


\section{LIST OF ACRONYMS}

$\begin{array}{ll}\text { BTEX } & \text { benzene, toluene, ethylbenzene, xylenes } \\ \text { BTX } & \text { benzene, toluene, xylene } \\ \text { CAP } & \text { Corrective Action Plan } \\ \text { CAR } & \text { Corrective Action Report } \\ \text { CERCLA } & \text { Comprehensive Environmental Response, Compensation, and Liability Act } \\ \text { DOE } & \text { Department of Energy } \\ \text { GRA } & \text { General Response Action } \\ \text { HTI } & \text { high-temperature incineration } \\ \text { LTTD } & \text { low-temperature thermal desorption } \\ \text { NCP } & \text { National Oil and Hazardous Substances Pollution Contingency Plan } \\ \text { NEPA } & \text { National Environmental Policy Act } \\ \text { NPDES } & \text { National Pollutant Discharge Elimination System } \\ \text { O\&M } & \text { operation and maintenance } \\ \text { ORR } & \text { Oak Ridge Reservation } \\ \text { OVD } & \text { organic vapor detector } \\ \text { POTW } & \text { Publicly Owned Treatment Works } \\ \text { QAVQC } & \text { quality assurance/quality control } \\ \text { RCRA } & \text { Resource Conservation and Recovery Act } \\ \text { TCLP } & \text { Toxicity Characteristic Leaching Procedure } \\ \text { TDEC } & \text { Tennessee Department of Environment and Conservation } \\ \text { TPH } & \text { total petroleum hydrocarbons } \\ \text { TSD } & \text { treatment, storage, or disposal } \\ \text { UST } & \text { underground storage tank } \\ \text { VOCs } & \text { volatile organic compounds }\end{array}$




\section{INTRODUCTION}

This document represents an addendum to the Corrective Action Plan (document number $\mathrm{Y} / \mathrm{SUB} / 92-99928 \mathrm{C} / 1$ ) for underground storage tanks 1219-U, 1222-U, 2082-U, and 2068-U located at Buildings 9720-15 and 9754-1, Oak Ridge Y-12 Plant, Oak Ridge, Tennessee. The site of the four noted underground storage tanks is commonly referred to as the "Rust Garage Facility" and will be so referenced in this document hereafter. The original Corrective Action Plan (CAP) for the Rust Garage Facility was submitted to the Tennessee Department of Environment and Conservation (TDEC) for review in May of 1992.

This addendum to the Rust Garage Facility CAP only applies to the "Corrective Actions Considered" (Chapter 7.0), "Corrective Actions Chosen" (Chapter 8.0), "Treatment Evaluation" (Chapter 9.0), "Proposed Implementation Schedule" (Chapter 10.0), and "Monitoring and Reporting" (Chapter 11.0) sections of the original CAP. All other chapters which comprise the original CAP remain unchanged and in effect. Applicable changes to Chapters 7.0, 8.0, 10.0, and 11.0 of the original CAP are presented in the remaining sections of this addendum. Chapter 9.0 of the original CAP is eliminated.

A combination of corrective action process options for remediation of contaminated soils at the subject site was proposed in the original Rust Garage Facility CAP. The approach involved excavation of the soils from the impacted areas of the subject site, on-site solid phase bioremediation of soil contaminants using a biological treatment bed, and final disposal of the treated soils in place at the treatment bed site. The remediation of contaminated groundwater at the subject site would be addressed by the Y-12 Plant Comprehensive Environmental Response, Compensation, and Liability Act (CERCLA) program under which corrective actions would be addressed as part of remedial actions for the S-3 Ponds groundwater plume.

During the time period after submission of the original CAP for the Rust Garage Facility, Y-12 Plant Underground Storage Tank (UST) Program personnel continued to evaluate improvements that would optimize resources and expedite the activities schedule presented in the original CAP. With regard to the biological treatment bed facility that was to be constructed for contaminated soil remediation, it was determined that there was a shortage of available and usable land space for the treatment bed facility (requiring 10 to 11 acres for construction) at the Y-12 Plant that was not already committed for other future projects. Also, due to the fact that the treatment bed facility would be classified as a waste treatment site, the Y-12 Plant National Environmental Policy Act (NEPA) group determined that an Environmental Assessment would be required for siting of the facility which would require a minimum of two years to complete.

Based on the determinations noted above, several revisions to the original corrective action process options for remediation of contaminated soils at the Rust Garage Facility are proposed. The revised approach for soil remediation will involve excavation of the soils from the impacted areas of the subject site, on-site thermal desorption of soil contaminants using a portable desorption unit, and final disposition of the treated soils by backfilling into the subject site excavations. The land space required for the thermal desorption unit is approximately 1.0 to 1.5 acres that is available at the Y-12 Plant, and does not require the performance of a NEPA Environmental Assessment because the unit is portable. Use of a thermal desorption unit will also decrease the total time required to complete soil remediation compared to solid-phase bioremediation. Thermal desorption technology was evaluated as part of the original Rust Garage Facility CAP and was selected as one of the top three technologies selected for soil remediation.

Corrective actions with regard to groundwater have been evaluated for the Rust Garage Facility. Based on this evaluation, remediation of groundwater under the Y-12 Plant CERCLA Program is proposed for the facility. Additional justification for the groundwater corrective action 
chosen, and information regarding integration of UST and CERCLA requirements, are discussed within this addendum. 


\subsection{CORRECTIVE ACTIONS CONSIDERED}

This section describes the screening of remedial technologies and the development of the top three corrective action options for soil remediation at the Rust Garage Facility. The identification and screening of technologies initially establishes a wide range of process options for consideration. Corrective action objectives are established and based on the preferred remediation actions. A screening process on the basis of established criteria is conducted for the soil media. Process options that are not applicable to petroleum contamination are eliminated. Using this method, the field of potential process options can be narrowed down to the most feasible and reliable technologies. The process options are assembled and developed into potential corrective action options. The potential corrective action options are further evaluated on the basis of effectiveness, implementability, and cost to arrive at the selection of the top three corrective action options for consideration.

\subsection{IDENTIFICATION OF POTENTIAL CORRECTIVE ACTION OPTIONS}

\subsubsection{Corrective Action Objectives}

According to the National Oil and Hazardous Substances Pollution Contingency Plan (NCP) the primary objectives should be:

- Select remedies that are protective of human health and the environment.

- Select remedies that maintain protection over time.

- Select remedies that minimize untreated wastes.

- Remedies that employ treatment must be given preference.

- Treatment must be appropriate for contaminants that comprise the principle threat at the site.

- Engineering controls are only appropriate for low-level threats when treatment is impractical.

- Institutional controls are only to be used alone to mitigate short-term impacts.

- Institutional controls can be used to supplement engineering controls for long-term waste management.

- Innovative technologies are only to be considered when there is significant reason to believe that they will work "as well" as other proven technologies.

- Groundwater should be returned to its beneficial use within a reasonable time frame.

Another objective to consider is that offsite transport and disposal is a least favored option.

\subsubsection{General Response Actions}

General Response Actions (GRAs) represent the universe of technologies that have the potential to provide for or contribute to contaminant remediation. GRAs include no action/institutional actions, containment actions, removal/extraction actions, collection/control actions, treatment actions, and storage/disposal/discharge actions.

\subsubsection{No Action/lnstitutional Actions}

This response involves no action being taken to implement remedial technologies to reduce the hazard potential to human or ecological receptors. If no action is taken, the contaminants may eventually flush to nearby creeks and streams. Natural biodegradation, dilution, or volatilization could also take place. Because available data are limited, it is not possible to accurately predict how long these natural processes would take; therefore, the 
potential impact on human health and the environment cannot be assessed. Although insufficient data exist, over time the area impacted by contamination will continue to increase, but the effective concentration of the contaminants will be reduced through dilution. Since total petroleum hydrocarbons (TPH) are the main contaminants present, volatilization will only have a small effect on contaminant reduction. Since this response does not meet the corrective action objective, the no action option will not be considered further.

Use of institutional actions as a means to protect human health and the environment when implemented with other remedial actions may also be considered. Institutional actions could involve the use of access restrictions through deed restrictions, physical barriers, and security personnel. Other autions may involve developing an alternate water supply at the remediation sites that have contaminated groundwater. Institutional actions may also include environmental monitoring of air, surface water, groundwater, soil, sediments, etc. to ensure that contaminants are not migrating offsite where they could impact public health and environmental receptors.

\subsubsection{Containment Actions}

Containment actions may include capping areas containing contaminated soil, or using subsurface barriers to minimize the movement of contaminated groundwater. Capping could be used to minimize the transport of contaminated surface material to the atmosphere or the infiltration/percolation of surface water/groundwater through the contaminated soil matrix. Subsurface barriers, either vertical or horizontal, can be used to minimize the transport of contaminants through the soil or sediments by infiltration or percolation.

\subsubsection{RemovalExtraction Actions}

The removal/extraction of the source or contaminated materials is achieved through soil/sediment excavation, bulk removal, injection/extraction techniques, demolition, or decontamination. Earth moving equipment can be used to excavate and exhume contaminated materials. Equipment can also be used to remove contaminated solid waste (drums and debris) from the grounds, structures, or waste piles. Extraction wells can be used to extract contaminated groundwater. Injection wells can be used to enhance the groundwater flow to extraction wells. Wrecking equipment can be used to demolish structures and buildings. Decontamination techniques can be used to decontaminate structures and solid surfaces.

\subsubsection{Collection/Control Actions}

Collection/control can involve surface controls, collection and storage systems, emission control, vapor collection, and sediment control. These remedial actions can reduce the mobility of the contaminants and can be used to retain contaminated waste streams for subsequent treatment. Collection/control technologies could also be used to collect and control the residuals from the treatment of contaminated wastes.

\subsubsection{Treatment Actions}

Treatment involves the use of in situ or ex situ physical, chemical, biological, thermal, and dewatering technologies to reduce or eliminate the toxicity, volume, or mobility of the contaminants of concern.

Physical technologies can be generally used on wastes to reduce the volume of the contaminated materials by physical separation techniques and segregation. Stabilization and solidification techniques can be used in situ or following removal. Soil washing, air stripping, soil flushing, land aeration, and adsorption/absorption are all physical processes. 
Chemical technologies can be used to alter the chemical structure of the waste constituents to produce a waste residue that is less hazardous than the original waste. Chemical processes can also separate the contaminants from solid waste media through chemical extraction or leaching techniques to reduce the volume or mobility of the contaminants. Chemical solidification, stabilization, and fixation techniques can be used to form a bond with the waste material, resulting in solids or stable materials that are resistant to leaching of contaminants.

Biological technologies are used mainly for degradation of organically contaminated media. Several well-developed biological technologies exist for the treatment of aqueous waste streams contaminated at various levels with nonhalogenated organics and some halogenated organics. Contaminated sludges and soils can be treated by solid-phase and slurry-phase processes. These processes have been developed and used to treat a wide range of contaminants such as pesticides, diesel fuel, gasoline, fuel oil, creosote, pentachlorophenol, and halogenated volatile organics.

Thermal treatment is a term associated with the use of elevated temperatures as the principal means of destroying, detoxifying, or physically stabilizing hazardous wastes. There are several thermal processing options such as incineration, infrared heating, wet air oxidation, pyrolysis, thermal desorption, and vitrification.

In Situ treatment involves various physical, chemical, biological, and thermal techniques to treat source contamination in place.

Dewatering techniques are mainly used on aqueous waste streams as a means to separate nonsoluble contaminants.

\subsubsection{Storage/Disposal/Discharge Actions}

Temporary storage could reduce the mobility of the waste materials by isolating the contaminants from further transport and minimizing the potential for short-term exposure of the population and impacts to the environment. Temporary storage action would involve the use of an engineered structure, existing or newly constructed, to contain the waste materials. This option is only considered as an interim action until a permanent treatment and/or disposal methodology is implemented.

Disposal involves the permanent and final placement of the waste materials in a manner that protects human health and the environment. Untreated waste can be disposed of onsite in an engineered facility, offsite in an approved and licensed disposal facility, or in a regulated landfill. Treated waste and concentrated wastes from treatment processes can be disposed in a similar manner.

Discharge involves the permanent and final placement of an aqueous waste stream in a manner that protects human health and the environment. Treated liquid waste can be discharged onsite to surface waters or injected into the ground. Offsite discharge can involve deep well injection, piping to a river/stream offsite, or discharge to the local Publicly Owned Treatment Works (POTW).

\subsubsection{Initial Screening Criteria}

The purpose of the initial screening process is to review and evaluate technologies and eliminate those inappropriate for site contaminants or site conditions at the Y-12 Plant Rust Garage Facility. This screening process is designed to eliminate actions that do not provide a permanent means to prevent or minimize the release of contaminants, or that cannot be implemented as a result of conditions at the site. The technologies and options reviewed as part 
of the screening process represent those currently being employed on a regular and successful basis at other petroleum-contaminated sites. Technologies that are untested or in the early stages of development are not reviewed.

The criteria used in the initial screening process are as follows:

- the applicability of a general response action to the affected media,

- the compatibility of a remedial technology with the contaminant of concern,

- the applicability of a remedial technology to the contaminant fate,

- the long-term durability of a process option,

- the volume and character of wastes generated by a process option,

- the management of a process option in a reasonable period of time, and

- the control of a process option over potential unknown or outside influences.

\subsubsection{Initial Screening of Technologies and Process Options}

The hierarchy of responses, technologies, and options for the initial screening of the soil contaminants is shown in Table 7-1. This table is formatted (as a flow chart) so that, for each general response action, different remedial technology types and various process options are presented. A brief description of each option is provided along with comments concerning elimination or selection for subsequent evaluation. The screening of remedial technologies is based on the characterization of contaminants identified at a given site. In the case of the Rust Garage Facility, remedial technologies were evaluated based on their abilities to remediate soil materials contaminated by TPH.

\subsubsection{No Action/Institutional Actions}

The remedial technologies screened for institutional actions included access restrictions and monitoring. Access restrictions include site security and deed restrictions. The only process option included within monitoring is soil sampling.

Site security involves the use of fences, berms, and signs surrounding the site to help prevent unauthorized access to the site. Security personnel can be used for controlling authorized access to the site. However, this process alone does not remedy the contaminant, and since site security is already in place at this location of the Y-12 Plant, this process option is not applicable.

Deed restrictions can be applied for the properties in the area of influence to require permits for digging, building, or any activity that can disturb the soils. However, this process alone does not remedy the contaminant, and since the contamination is confined to U.S. Department of Energy (DOE)-owned property, this process option is not applicable.

Monitoring of soils involves taking confirmatory samples in the area before and after remediation. This process option is required by the Tennessee Department of Environment and Conservation (TDEC); therefore, it is applicable.

\subsubsection{Containment Actions}

The remedial technologies screened for containment actions included capping, vertical barriers, and horizontal barriers. Capping includes clay, asphalt, concrete, geosynthetic, and multilayered materials. Vertical barriers include slurry walls, grout curtains, sheet piles, and vibrating beams. Horizontal barriers include grout injection, block displacement, liners, and ground freezing. 
Table 7-1. Initial Screening of Technologies and Process Options for Rust Garage Facility Soil Remediation

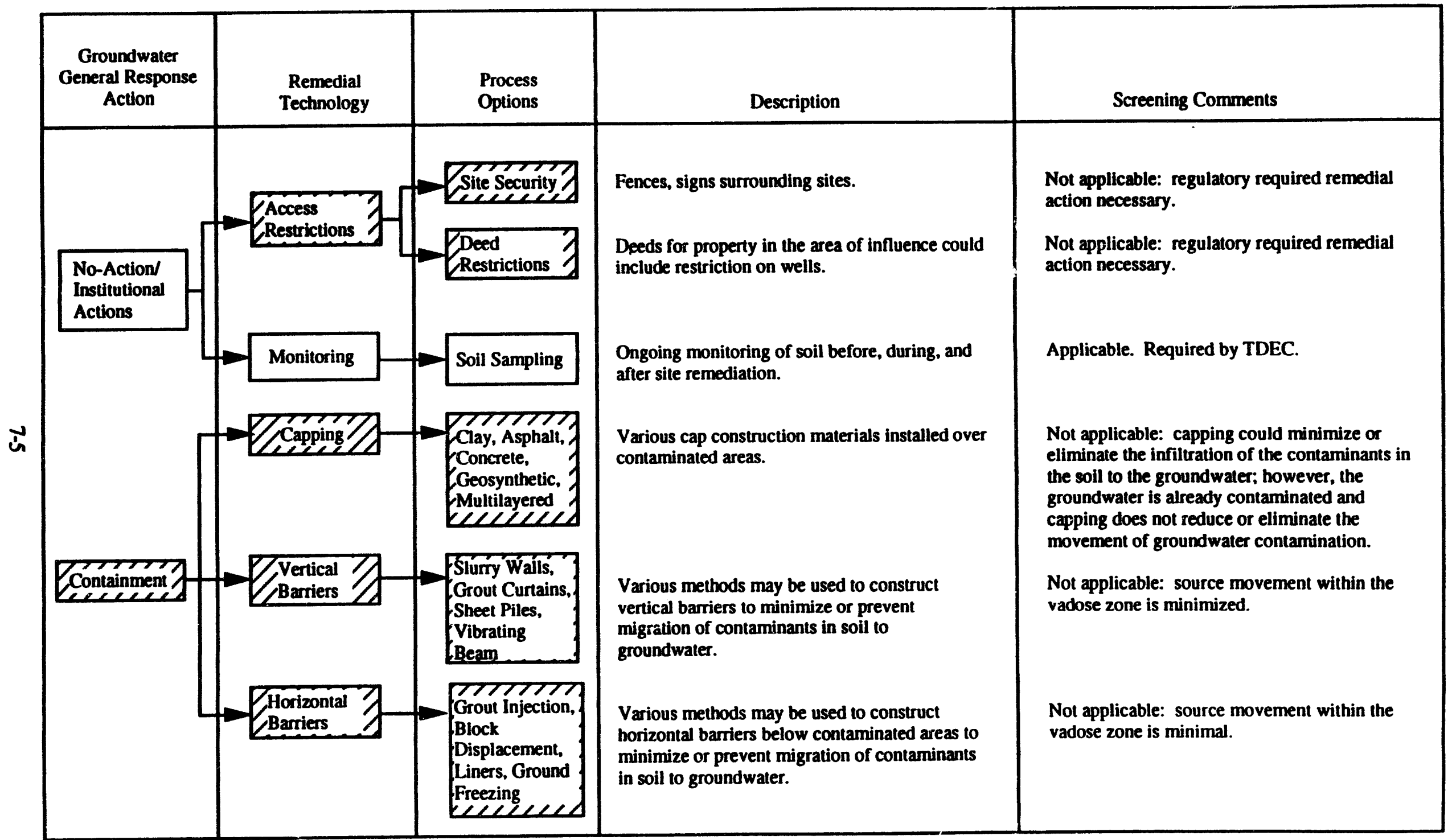


Table 7-1. (continued)

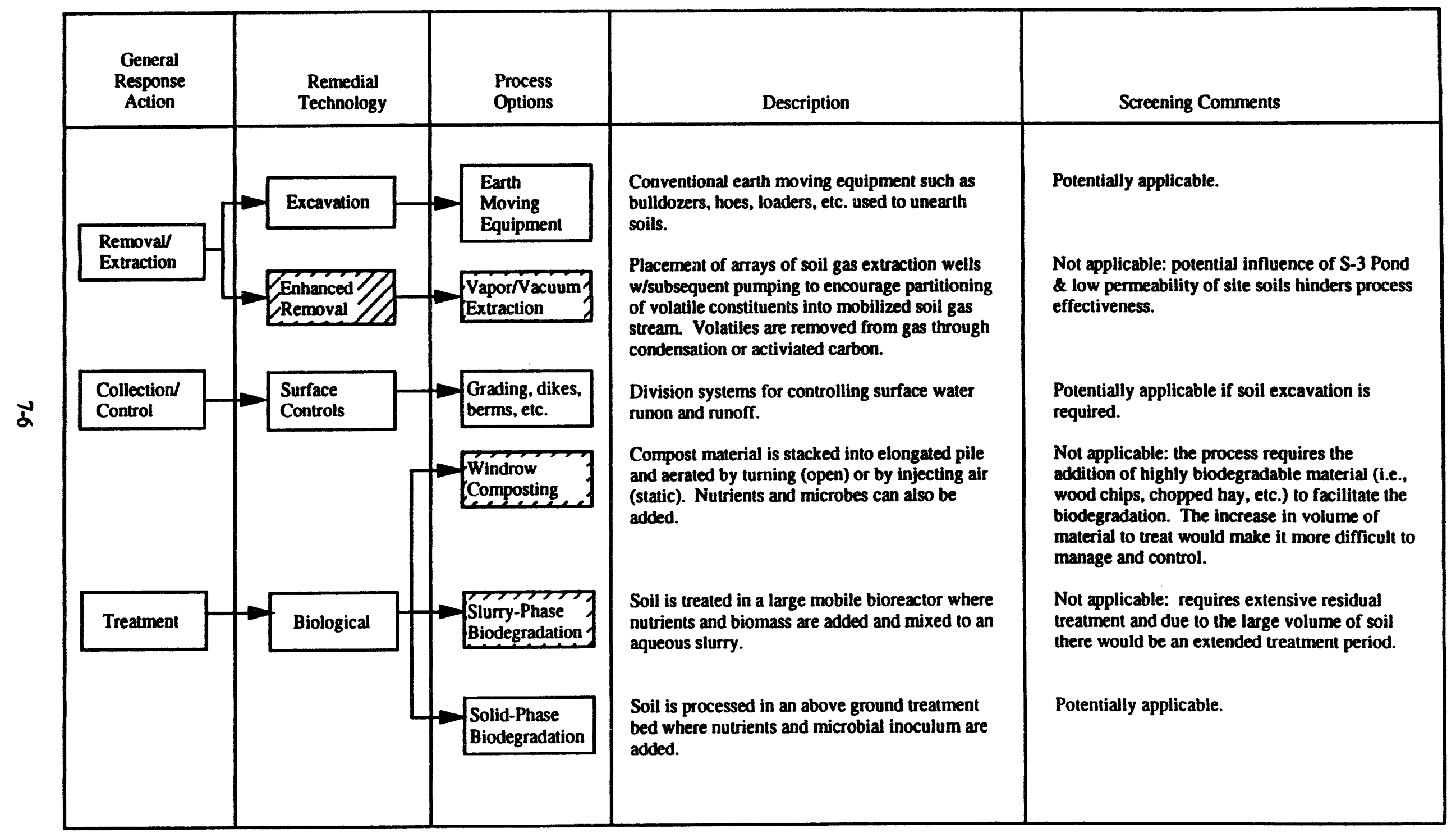

Indicates the technologies and processes eliminated from consideration. 
Table 7-1. (continued)

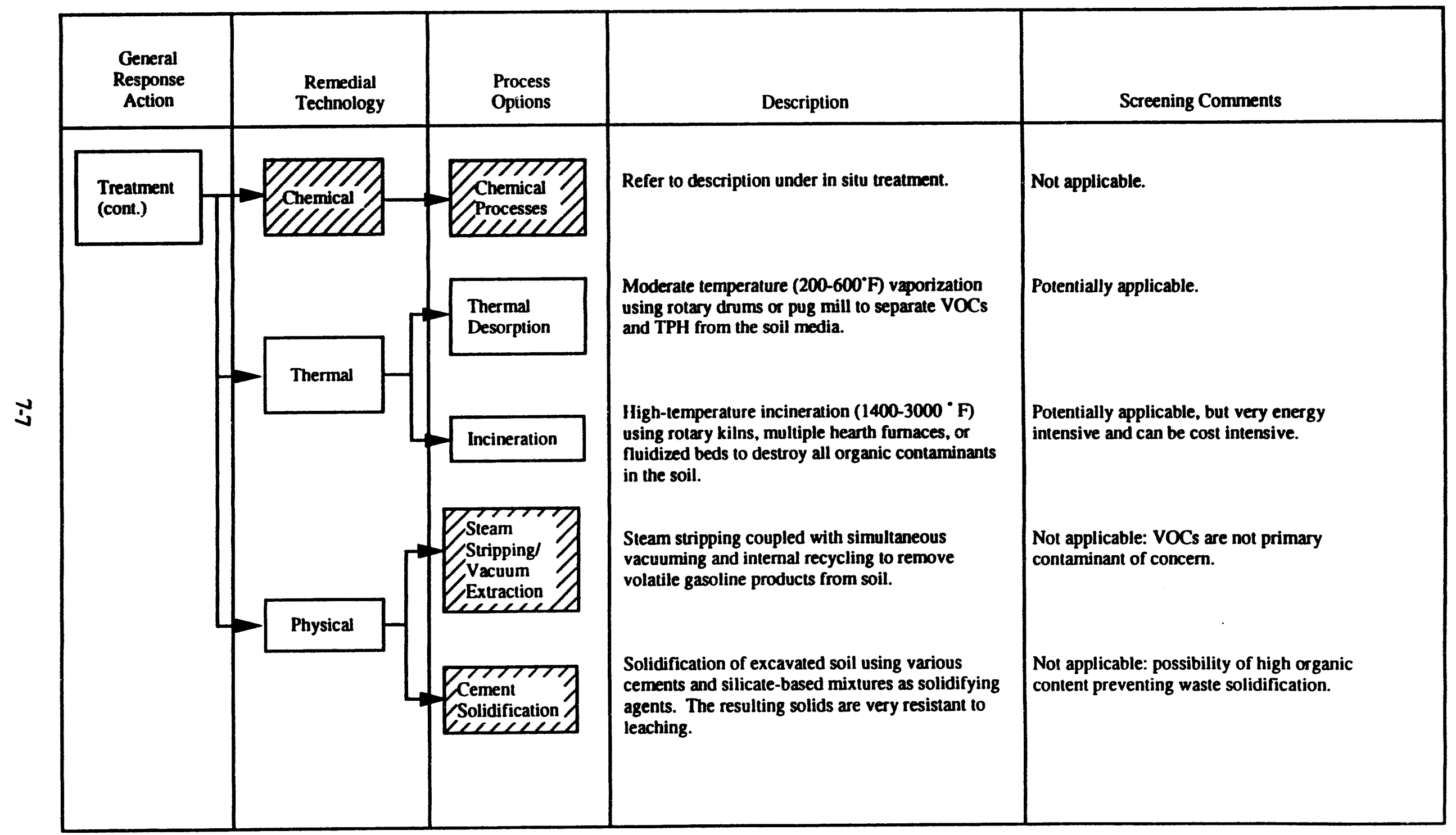

Indicates the technologies and processes eliminated from consideration. 
Table 7-1. (continued)

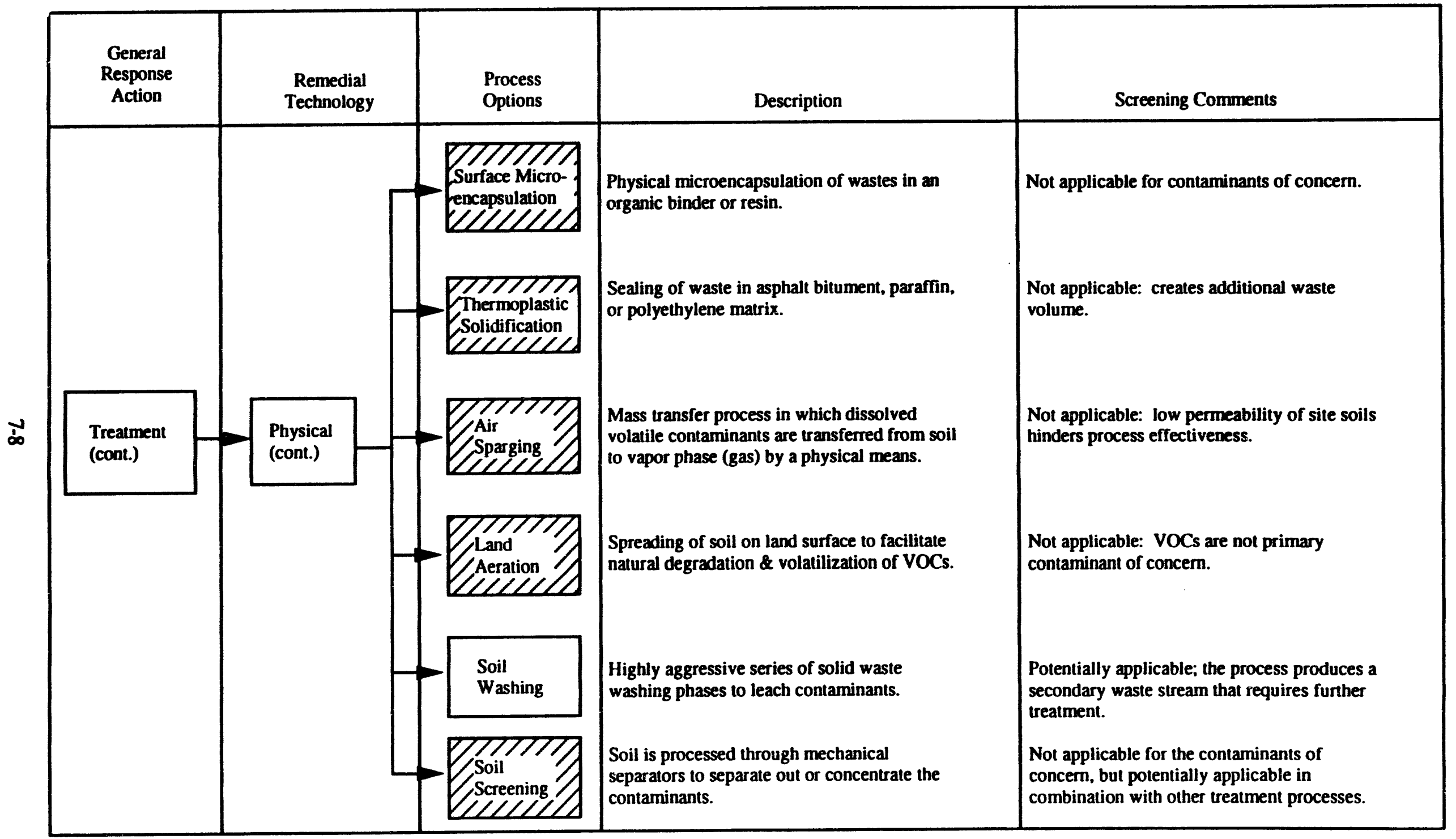


Table 7-1. (continued)

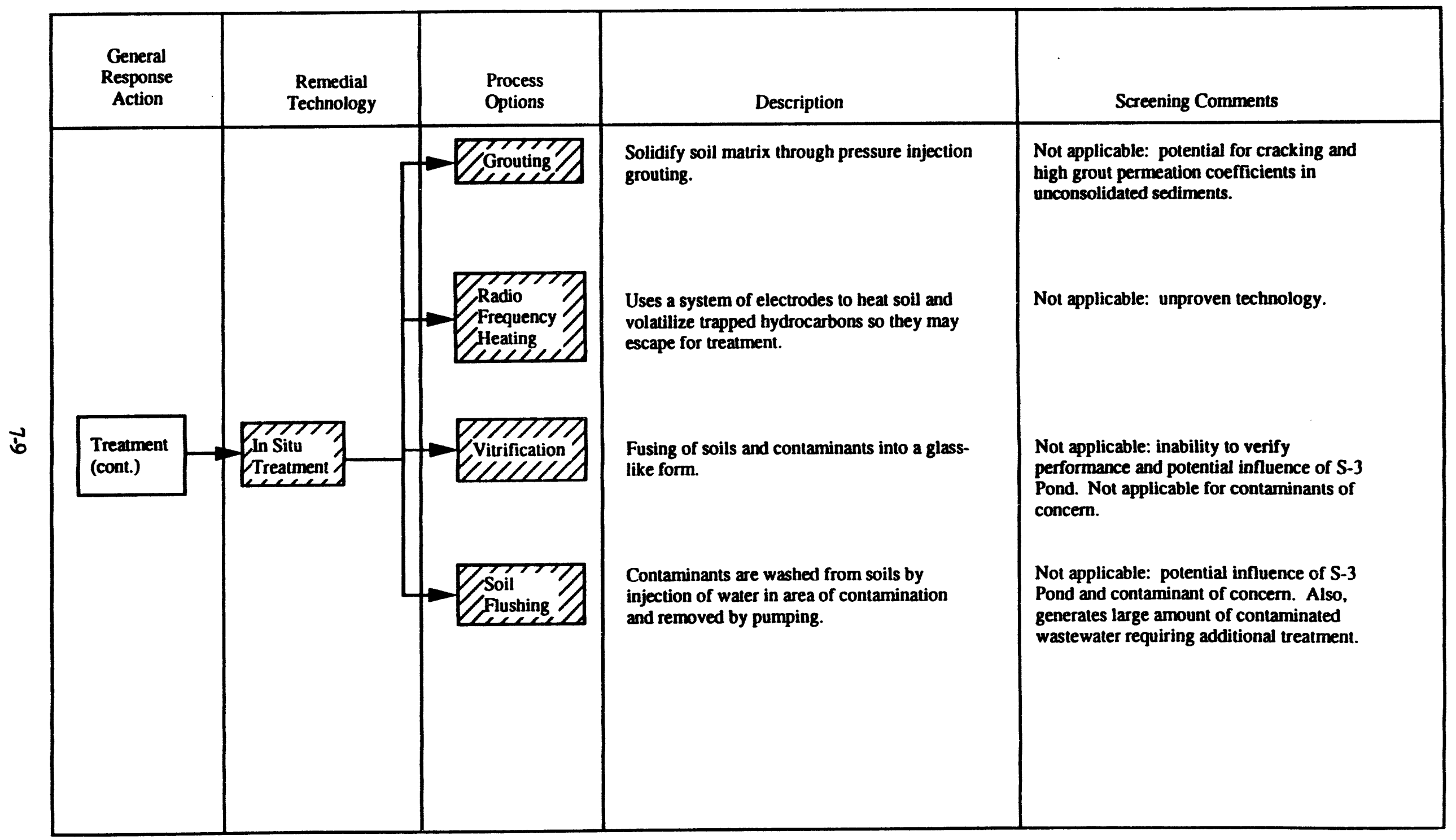


Table 7-1. (continued)

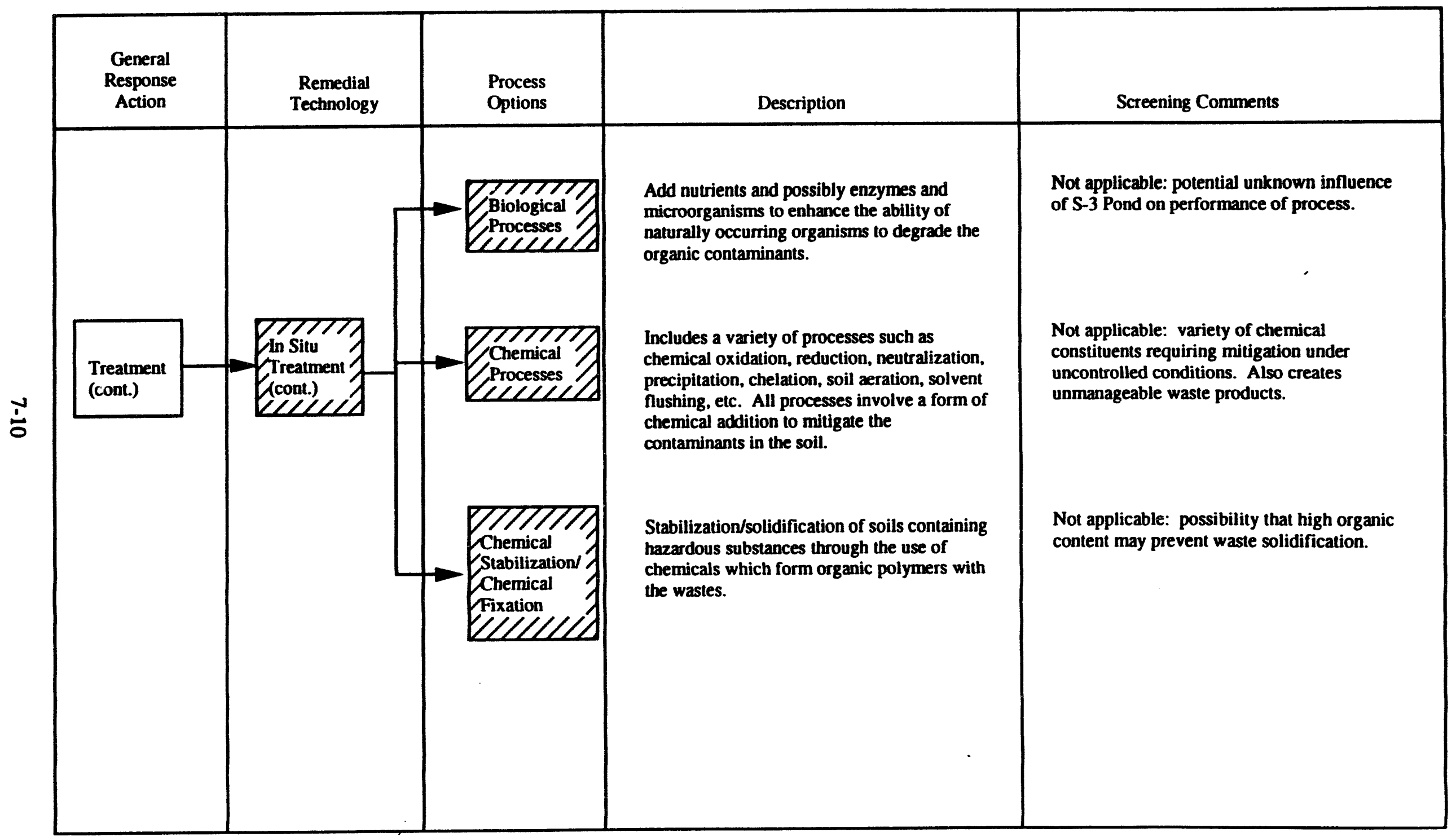


Table 7-1. (continued)

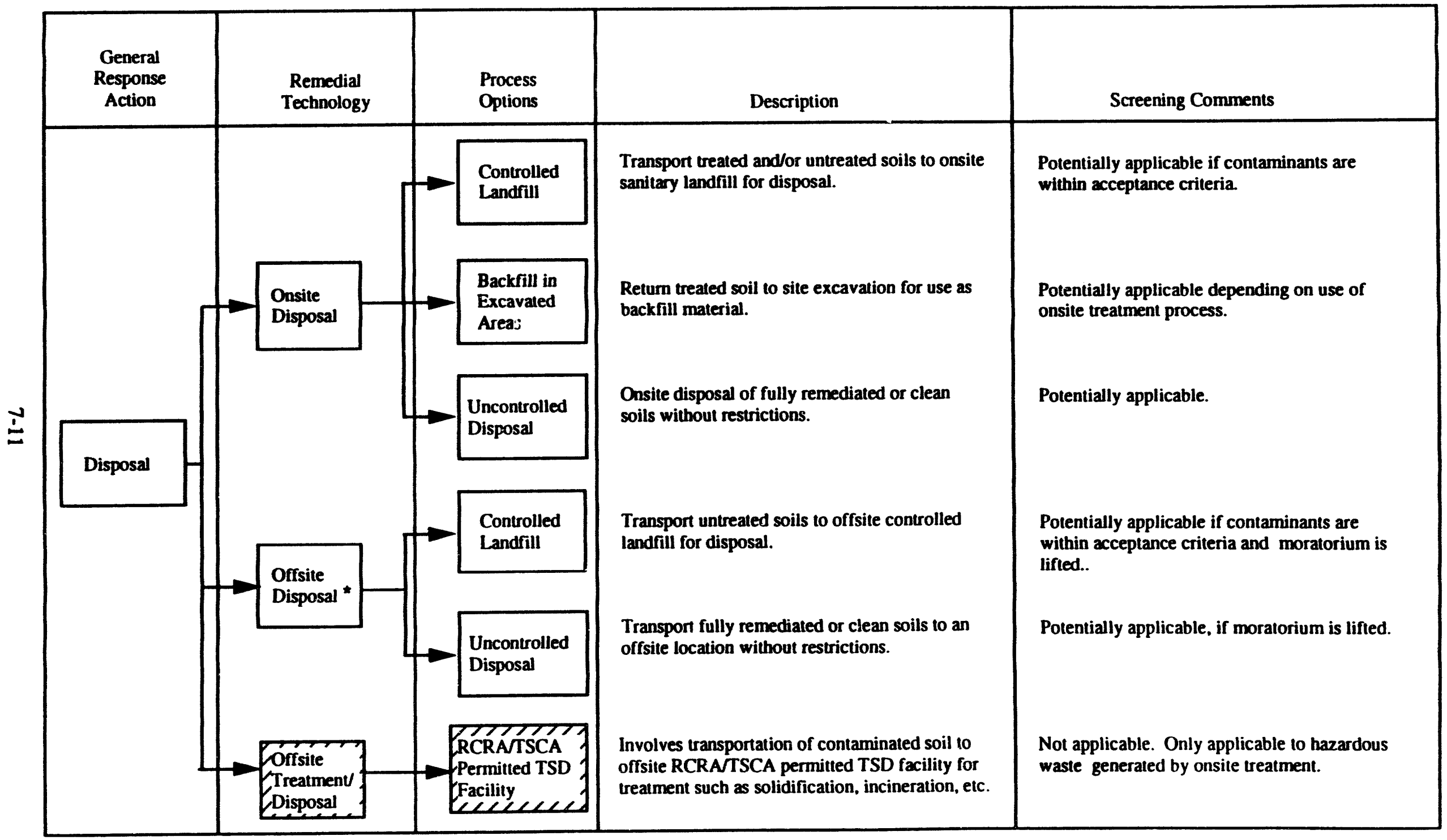

* Not currently applicable due to offsite waste disposal moratorium. Indicates the technologies and processes eliminated from consideration. 
Various methods may be used to construct caps to minimize or prevent migration of contaminants within the soil to the groundwater. However, the contaminant has already infiltrated down to the water table, and capping does not reduce or eliminate the movement of previously contaminated groundwater. Therefore, process options are not applicable.

Various methods may be used to construct vertical and horizontal barriers to minimize or prevent migration of contaminants within the soil to the groundwater. However, the contaminant has already reached the groundwater; therefore, these process options are not applicable.

\subsubsection{Removal/Extraction Actions}

The remedial technologies screened for removal/extraction actions included soil excavation and enhanced removid.

Excavation of soil can be conducted using conventional earth moving equipment such as bulldozers, backhoes, loaders, etc. to remove the soil from the ground for treatment and/or disposal. This process option is a common practice and is potentially applicable if ex situ treatment/disposal or direct disposal corrective actions are chosen.

The enhanced removal technique of vapor/vacuum extraction uses a series of injection/extraction wells to remove soil vapors so that contaminants can be separated and treated. Since this process extracts not only soil vapors, but potentially groundwater vapors, this process is not applicable due to the influence of the former S-3 Ponds.

\subsubsection{Collection/Control Actions}

The remedial technologies screened for collection/control actions only included surface controls. Surface controls involve diversion systems such as grading, dikes, and berms for controlling surface water runon and runoff. Surface water is not a medium of interest; however, surface control techniques would have to be implemented for soil excavation and certain site preparation needs. Therefore, this process option is retained for further consideration in combination with excavation.

\subsubsection{Treatment Actions}

The initial screening for treatment actions included biological, chemical, thermal, physical, and in situ remedial technologies.

Biological process options screened involved window composting, slurry-phase biodegradation, and solid-phase biodegradation. These processes have been demonstrated effective for treating soil contaminated with petroleum products.

Windrow composting involves adding highly biodegradable material, such as wood chips and chopped hay, to the excavated soil and stacking the compost material into elongated piles. Open windrows are aerated by tuming and static windrows are aerated by injecting air through piping placed in the piles. This process option was considered not applicable because the volume of material at the subject site would be increased and become more difficult to manage and control.

Slurry-phase bioremediation involves mixing the soil into an aqueous slurry inside a mobile bioreactor where nutrients and biomass are added 20 degrade the contaminant. This process option was considered not applicable because the process is limited by the volume of 
waste it can treat over a period of time. The process generates additional volumes of waste, and the process could involve extensive residual treatment.

Solid-phase bioremediation involves placing the contaminated soil in an aboveground, lined bed where nutrients and microbial inocula are added to facilitate the biodegradation process. This process option is considered technically feasible; therefore, it is potentially applicable.

Chemical process options can include a variety of processes such as chemical oxidation, reduction, neutralization, precipitation, chelation, solvent flushing, and others. All processes involve the addition of chemicals to mitigate the contaminants in the soil. All the chemical process options were considered not applicable because of the variety of chemical constituent residuals requiring further treatment under uncontrolled conditions and because these processes create additional waste which makes them more difficult to manage.

Thermal process options screened included low-temperature thermal desorption and incineration. These processes have been demonstrated effective for treating petroleum contaminated soils.

Low-temperature thermal desorption (LI TD) is a process that uses moderate heat $\left(200-600^{\circ} \mathrm{F}\right)$ to vaporize organic contaminants in soil. LTTD systems are physical separation processes and are not designed to destroy the organic contaminants. This process option is considered technically feasible; therefore, it is potentially applicable.

High-temperature incineration (HTI) is a process that uses high temperatures (1400$3000^{\circ} \mathrm{F}$ ) in devices such as rotary kilns, multiple hearth fumaces, or fluidized beds to destroy all organic contaminants in the soil. This process option is very energy intensive and can be cost intensive; however, it is considered technically feasible; therefore, it is potentially applicable.

Physical process options screened included steam stripping/vacuum extraction, cement solidification, surface micro-encapsulation, thermoplastic solidification, air stripping, land aeration, soil washing, and soil screening.

Steam stripping/vacuum extraction involves steam stripping coupled with simultaneous vacuuming and internal recycling to remove volatile gasoline products from soil. Volatile organic compounds (VOCs) are not the primary contaminant of concern.

Cement solidification, surface microencapsulation, and thermoplastic solidification involve the solidification or sealing of excavated soil using various cements, resin, organic binders, asphalt, and silicate-based mixtures as solidifying agents. The resulting solids are very resistant to leaching. Since these processes involve an increase in the volume of waste and are possibly influenced by the organic contents that may prevent complete solidification, these process options are considered not applicable for the contaminants of concern.

Air sparging is a mass transfer process in which dissolved VOCs are transferred from soil to vapor phase (gas) by physical means. Since VOCs are not the primary contaminants of concern, this process option is considered not applicable.

Land aeration involves the spreading of soil on land surface to facilitate natural degradation and volatilization of organic compounds. Generally, the primary aeration treatment mechanism is volatilization. Since the principle contaminant of concern (TPH) is primarily semi-volatile, treatment would be a relatively slow process. Therefore, this process option is considered not applicable. 
Soil washing involves a highly aggressive series of solid waste washing phases to leach contaminants. This process option is potentially applicable; however, the residual waste stream may require additional treatment.

Soil screening involves processing soil through mechanical size separators to separate out or concentrate contaminants associated with a particular particle size. There is no evidence that petroleum contamination adheres to any particular particle size, and the contaminated soils at Rust Garage are fairly uniformly distributed clay particles; therefore, this process option is not considered applicable. However, mechanical screening may be used as a pretreatment step for other processes.

In situ process options screened included grouting, radio frequency heating, vitrification, soil flushing, biological processes, and chemical processes. All of these process options were considered not applicable, primarily because of the potential influence of the S-3 Pond contaminants and the generation of additional waste streams.

\subsubsection{Disposal}

Disposal techniques screened included onsite disposal, offsite disposal, and offsite treatment/disposal. Onsite disposal process options screened included controlled landfill, backfill in excavated areas, and uncontrolled disposal. Offsite disposal process options included controlled and uncontrolled disposal. The only offsite treatmentdisposal option screened involved a Resource Conservation and Recovery Act (RCRA)/Toxic Substances Control Act (TSCA) permitted treatment, storage, or disposal (TSD) facility.

Onsite or offsite disposal at a controlled landfill involves transport to a regulated landfill site of treated or untreated soils that meet the disposal acceptance criteria. Uncontrolled disposal at an onsite or offsite location involves the disposal of uncontaminated or fully remediated soils without restrictions. All process options are technically feasible, depending on the treatment process selected, if any, and the level of contamination; however, since a current moratorium exists for offsite transport of waste from the Y-12 Plant, the offsite controlled landfill is the least preferred method.

The onsite disposal process option of backfill in excavated areas involves returning treated soil to the site of excavation for use as backfill material. The time to treat the soil limits how fast the excavated site can be backfilled with the treated material. Since the excavation site would require immediate backfilling, this process option is dependent on the availability of an onsite treatment option running concurrently with excavation.

The offsite treatment/disposal process option of using a RCRATTSCA permitted TSD facility involves transportation of contaminated soil to an offsite RCRA TSD facility for treatment such as solidification, incineration, etc. This process option is considered not applicable since the contaminants at the Rust Garage Facility are not currently classified as hazardous waste.

\subsubsection{Development of Corrective Action Options}

This section describes the development of corrective action options from the process options that passed the initial screening evaluation for soil remediation. The remaining technology options for the general response actions are combined to form potential soil corrective action options for evaluation in Section 7.2.1. The general response actions retained for further evaluation include removal extraction, treatment, and disposal. Conventional excavation equipment would be used to remove contaminated soil for treatment and/or disposal. The treatment options include: thermal (incineration and thermal desorption), physical (soil 
washing), and biological (solid-phase bioremediation). Disposal includes onsite and offsite options for treated soil and residuals from treatment. The remaining technology options are briefly discussed below.

\subsubsection{Removal/Extraction}

Preliminary studies indicate any type of in situ treatment would follow a preferential path through the soil matrix. All of the remaining process options involve soil removal prior to treatment. The removal action for all potential corrective action options would involve the removal of the source of contamination by soil excavation methods. Conventional excavation equipment would be used for the removal of the contaminated soil at the site. The Rust Garage Facility is an active maintenance and garage area, and includes buildings and utilities within close proximity of the contaminated area. Smaller equipment or manual-excavation techniques may be implemented when required for this option. Certain institutional actions, such as soil monitoring and surface controls, are considered part of this technology option. Implementation of this action is the same for all six of the treatment options. In addition, the asphalt pavement and gravel base will be excavated to obtain access to the contaminated soil and will require disposal at a suitable disposal facility.

\subsubsection{Treatment (Thermal, Physical, and Biological)}

The treatment options most applicable for corrective action are thermal desorption, incineration, soil washing, and solid-phase bioremediation. Each of these four process options requires that the contaminated soils be excavated from impacted areas before treatment. The thermal desorption method volatilizes the petroleum contaminants by heating the excavated soils to temperatures usually between $200^{\circ}$ to $600^{\circ} \mathrm{F}$ using a mobile unit. Incineration involves the thermal decomposition of organic constituents by cracking and oxidation reactions at very high temperatures, usually between $1400^{\circ}$ and $3000^{\circ} \mathrm{F}$. In the soil washing method, the excavated soils are washed repeatedly with water to remove contaminants. The solid phase bioremediation treatment method consists of excavating contaminated soils and transporting them to a prepared site for treatment with the introduction of nutrients and microorganisms.

Although each of the active treatment methods (thermal desorption, incineration, and soil washing) would remediate the contaminated soils, each would produce a waste product requiring controlled disposal or secondary treatment prior to disposal. Thermal desorption would produce waste soil that could be used as fill material or landfill cover. The volume of this material would be slightly less than that of the originally excavated soil. The inorganic constituents of the contaminated soil would be the only portion of the material remaining after incineration. These inorganics are collected as bottom ash from the combustion chamber or fly ash particulate suspended in the combustion gas stream. The bottom ash waste is usually stabilized and disposed of in a controlled landfill or used as cover material for a landfill. Soil washing would produce large quantities of wastewater requiring secondary treatment equipment. The petroleum contamination is associated with the fine clay particles that leave the process as a condensed waste stream. This condensed waste stream requires additional treatment, and the clay particles make up the majority of the soil located at the Rust Garage Facility. The passive biological treatment method should not produce any secondary wastes and treated soils could remain at the treatment site.

\subsubsection{Disposal (Onsite or Onisite)}

Disposal includes the onsite and offsite options of controlled and uncontrolled disposal. For controlled disposal at a sanitary landfill, TDEC requires that the treated waste Toxicity Characteristic Leaching Procedure (TCLP) extract for benzene and TPH not exceed $0.5 \mathrm{ppm}$ and $10.0 \mathrm{ppm}$, respectively (TDEC, 1990). Landfill capacity limitations and potential institutional 
factors may limit the use of onsite disposal. The current moratorium against the offsite transportation of low-level waste from the Oak Ridge Reservation (ORR) restricts the use of offsite disposal. Due to the historical use of the west end of the $Y-12$ Plant for waste disposal staging and/or transport, there is a possibility of radiological contamination and prudence in waste disposal is implied.

Controlled disposal involves the disposal of treated or untreated soil meeting the acceptance criteria at a sanitary landfill. The treated soil residuals from the incineration process (ash) are only considered suitable for controlled disposal as monofill material. Treated soils from the thermal desorption process are considered suitable for disposal at a sanitary landfill as cover material. After additional treatment, the concentrated waste fraction of the soil washing process can be considered for controlled disposal as cover material at a sanitary landfill.

Uncontrolled disposal involves using the treated material with suitable characteristics as clean fill or for direct land application. Soil treated by thermal desorption is only considered suitable as clean fill; however, if the soil is mixed with organics and/or fertilizers it can be made suitable for direct land application. The uncontaminated fraction of the soil washing process can also be considered for uncontrolled disposal as fill material. Bioremediated soils are considered suitable for direct land application.

There is no confirmation that contaminated soils at the Rust Garage Facility site meet the definition of a RCRA hazardous waste. If some of the soils are determined to meet the definition of RCRA hazardous waste, the disposal options will be revised to include the RCRA regulatory requirements. As a contingelcy measure, soils found to be classified as RCRA hazardous waste will be segregated from nonhazardous soils and properly stored prior to final disposal (yet to be determined).

\subsubsection{Potential Corrective Action Options}

Contaminated soil excavation with direct disposal of all excavated soil is not considered a viable corrective action option and will not be considered further. However, excavation, treatment, and disposal combine into potential corrective action options. The potential corrective action options include:

- excavation, onsite thermal treatment (incineration or thermal desorption), and onsite/offsite controlled/uncontrolled disposal;

- excavation, onsite active physical treatment (soil washing), and onsite/offsite controlled landfill disposal; and

- excavation, onsite biological treatment (solid-phase), and onsite uncontrolled disposal.

\subsection{Selection of Corrective Actions}

This section presents an evaluation of the potential corrective action options based on their effectiveness, implementability, and cost. The options are evaluated in relation to the volumes of waste material and site-specific constraints. Table 7-2 provides a summary of the evaluation of the remaining process options for the Rust Garage Facility contaminated soil. 
Table 7-2. Evaluation of the Selected Process Options for Soil Remediation

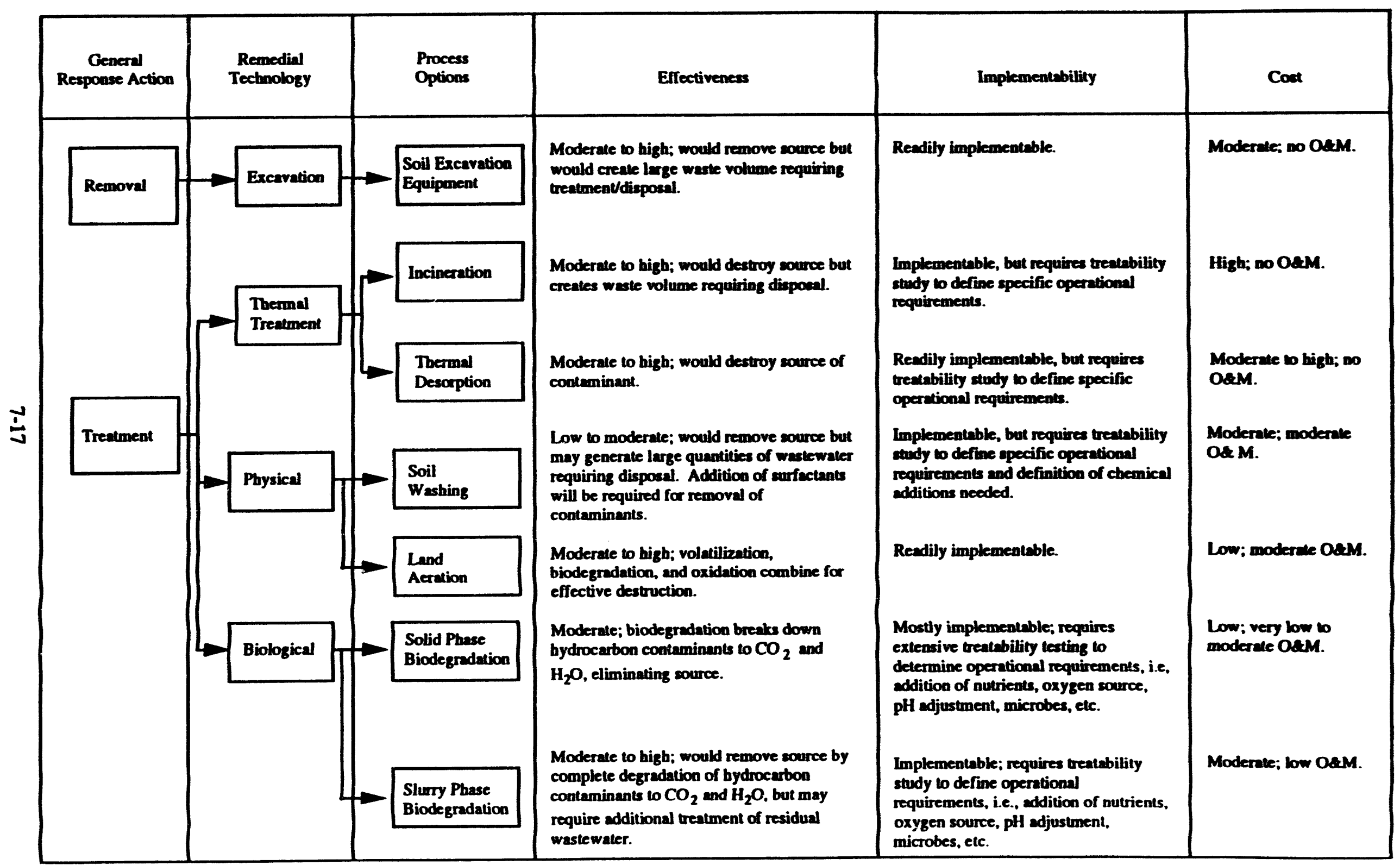




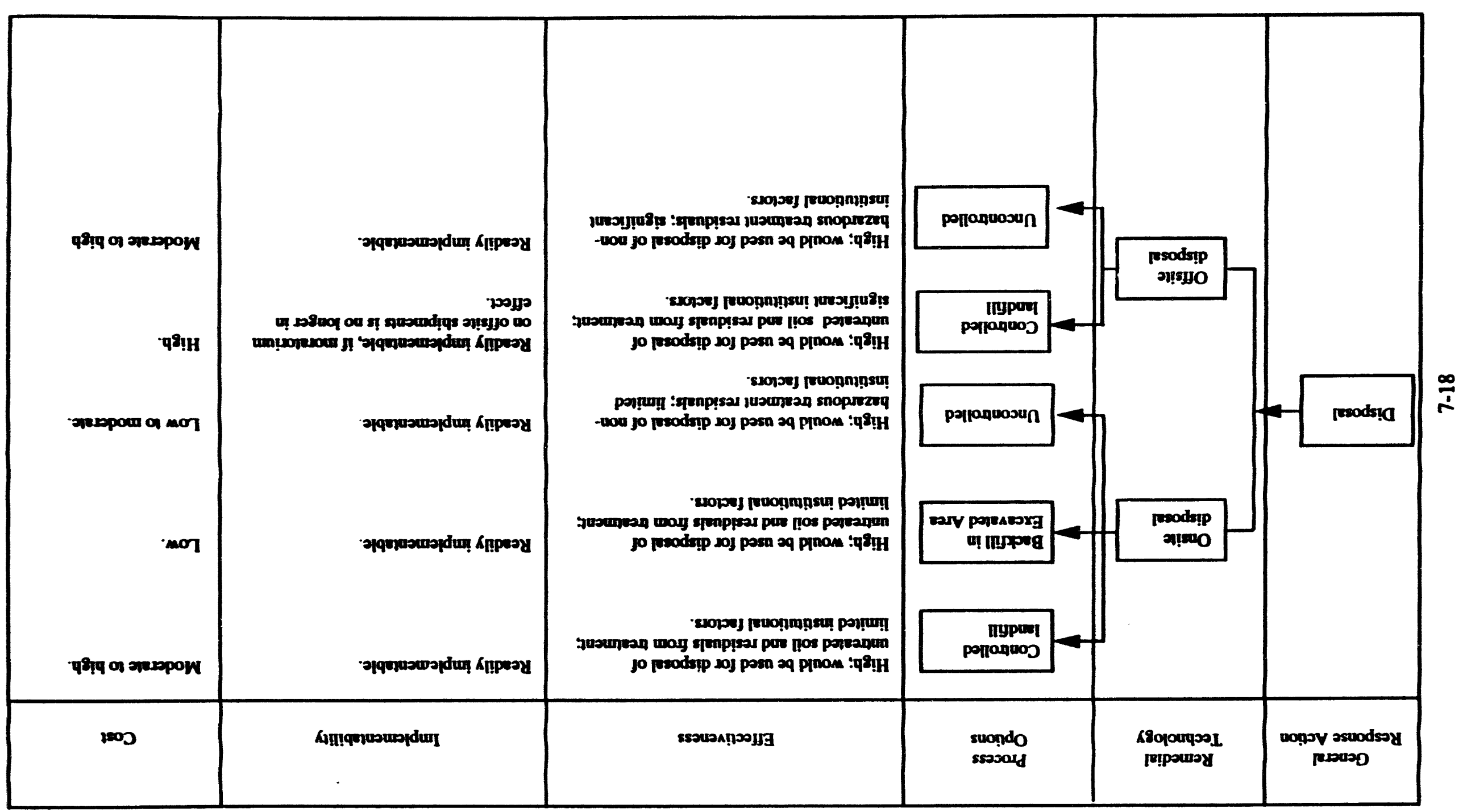

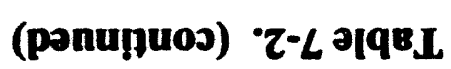




\subsubsection{Evaluation Criteria}

\subsubsection{Efifectiveness}

The identified corrective action options are evaluated to ensure they effectively protect human health and the environment and to satisfy the corrective action objectives identified for the media of interest. The ability and effectiveness of each technology option to reduce the contaminant concentrations or exposure levels or to sufficiently recover contaminated media for subsequent treatment are evaluated. The performance evaluation of a particular corrective action process involves a technical evaluation of the ability of the option to achieve the corrective action objectives.

The performance evaluation also necessitates determining how effective and reliable the technology option would be with respect to the contaminants and conditions at the site. Reliability is a major consideration in determining effectiveness due to the operation and maintenance (O\&M) requirements of most technology options and the importance of protecting public health and the environment during remediation activities. The long-term management of residual contamination and/or untreated waste reduces the effectiveness of a technology; therefore, the duration of long-term management is evaluated as part of the technology's effectiveness.

\subsubsection{Implementability}

The implementability evaluation criteria include both technical and administrative considerations. Technical feasibility involves the availability and constructability of the technology option and the construction and implementation time frame. Implementation time and the period for beneficial results to be realized are critical to protecting public health and the environment.

The administrative considerations of implementability include: the ability to obtain the necessary approvals from regulatory agencies; availability of TSD facilities and associated capacities; and availability of necessary equipment and skilled workers to implement the technology.

\subsubsection{Cost}

Relative capital costs and O\&M costs are used rather than detailed estimates. The complexity of the technology option will determine the detail required for the cost estimates. The cost analysis is based on engineering judgment, available vendor quotes, and costs reported from similar corrective actions implemented at other UST sites.

\subsubsection{Evaluation of Corrective Actions}

The general response actions and remedial technologies evaluated in this section include: Removal/Extraction, Thermal Treatment, Physical Treatment, Biological Treatment, and Disposal. The criteria described in Section 7.2.1 were used to evaluate the remedial technologies within each of the general response actions remaining after the initial screening. The purpose of this evaluation is to identify the most effective, implementable, and cost-effective process options for attaining the Rust Garage Facility corrective action objectives for soil remediation.

\subsubsection{Removal/Extraction}

The removal action by soil excavation methods would effectively eliminate the source of contamination from the site but would generate a large volume of waste requiring treatment 
and/or disposal. Short-term considerations of worker safety and environmental impacts due to dust and potential surface runoff would be considered by developing and implementing a Health and Safety Plan for the excavation activities (including dust control activities) and by including surface water runon/runoff control in the corrective action design.

Conventional construction equipment would be used for excavating the contaminated soil at the site and, therefore, this action is readily implementable. The Rust Garage Facility is an active maintenance and garage area, and includes buildings and utilities within close proximity of the contaminated area requiring excavation. The limited available space may impact the use of larger conventional excavation equipment in some areas and, therefore, may slow down the removal action. Excavation is required for all of the remaining treatment process options. The capital costs for the excavation action are moderate with no O\&M costs.

\subsubsection{Thermal Treatment (Incineration)}

Incineration involves the thermal destruction of organic constituents by cracking and oxidation reactions at high temperature. The organic components of the contaminated soil are converted into carbon dioxide and water. The inorganic constituents of the contaminated soil would not be destroyed by incineration and would exit the incinerator as either bottom ash from the combustion chamber or fly ash particulates from the baghouse or scrubber. The bottom ash waste is usually stabilized with water, for workability, and landfill disposed. Air pollution control systems are used to remove volatile organics and other hazardous air pollutants from the effluent gas stream. The waste stream generated by the air pollution control system may also require an additional treatment operation prior to disposal.

A major consideration in evaluating the effectiveness of incineration is based on the thermal conductivity and heating value of the waste. The inability of the contaminated soil to transfer heat and maintain combustion requires the addition of an auxiliary fuel in order to obtain the necessary performance standards for destruction of organics. High concentrations of water in the contaminated soil would also detract from the operational effectiveness of incineration.

The treated soil would be considered for disposal as monofill material at a landfill. This option provides for the removal of the contaminant source and, therefore, provides for the overall protection of human health and the environment. The performance of this particular corrective action process has been proven successful at a number of similar sites and is considered to be reliable overall.

The time frame for completion of this action is considered acceptable because of the limited volume of contaminated soil to be removed and the proven performance of this treatment process. Incineration has been proven effective and reliable at hazardous waste sites and similar UST sites.

Incineration of petroleum contaminated soils has not been previously implemented at the ORR. Administrative and regulatory considerations may impact the implementabilty of this option due to potential permit requirements and/or environmental impact evaluations. There are numerous vendors with the necessary equipment and skilled workers to implement this technology. There would be no long-term management of residual contamination and/or untreated waste due to the complete removal of the contaminants. Capital costs would be high with no O\&M. 


\subsubsection{Thermal Treatment (Thermal Desorption)}

Thermal desorption involves the separation of organic contaminants by heating soils from $200^{\circ} \mathrm{F}$ to $600^{\circ} \mathrm{F}$. This option would physically separate the organic contaminants from the contaminated soil. Dust particles and organic contaminants exit the heating unit as exhaust gas. The dust particles are collected in a baghouse or scrubber. The organic compounds are incinerated in an afterburner or adsorbed by an activated carbon filter. The soil would be considered as fill material or as cover material for disposal at a landfill. This option provides for the removal of the contaminant source and, therefore, provides for the overall protection of human health and the environment.

The time frame for completion of this action is considered acceptable because of the limited volume of contaminated soil to be removed and the proven performance of this treatment process. Thermal desorption has been proven effective and reliable at similar underground storage tank (UST) sites. This technology has not been previously implemented at ORR.

Administrative and regulatory considerations may impact the implementabilty of this option due to potential permit requirements and/or environmental impact evaluations. There are numerous vendors available with the necessary equipment and skilled workers to implement this technology. There would be no long-term management of residual contamination and/or untreated waste due to the removal of the contaminants and subsequent disposal. Capital costs would be moderate to high with no O\&M.

\subsubsection{Physical Treatment (Soil Washing)}

Soil washing involves the repeated washing of contaminated soils with water to remove the contaminants of concern. Certain surfactants or chemical addition may be required to facilitate adequate removal of the petroleum hydrocarbons. Large volumes of wastewater would be generated and would require additional onsite equipment for treatment prior to disposal or discharge.

The soil washing process would separate the contaminants and provide for a reduction in contaminated soil volume. Additional treatment operations would be required to degrade or stabilize the concentrated contaminated soil. In addition, soil washing is difficult to implement effectively in clayey soils, which is the major component of the soil matrix at the Rust Garage Facility. This technology has not been previously implemented at ORR.

Administrative and regulatory considerations may impact the implementabilty of this option due to potential permit requirements and/or environmental impact evaluations. There would be long-term management of residual contamination from the treatment process. There are vendors available with the necessary equipment and skilled workers to implement this technology. Soil washing has been proven effective and reliable for separation of petroleum hydrocarbons at similar UST sites. Capital costs would be moderate with moderate O\&M.

\subsubsection{Biological Treatment (Solid Phase Bioremediation)}

Biological treatment of the excavated contaminated soil would involve the aerobic degradation by a solid phase bioremediation process. A bioaugmentation (addition of microorganisms) biological treatment process involves excavating the contaminated soil and transporting it to a designated location for biological treatment. The soils would be treated in biological cells constructed for the volume of soil excavated. Aeration and nutrient addition systems would supply nutrients, oxygen, water, and microbes as needed during the operation of the process. 
Biological treatment removes the source of contamination by biological decomposition of the petroleum contaminants below action levels. This option would satisfy the corrective action objectives identified for the soil. This technology has not been previously implemented at ORR.

Administrative and regulatory considerations may impact the implementabilty of this option due to potential permit requirements and/or environmental impact evaluations. There would be no long-term management of residual contamination from the treatment process due to the decomposition of the contaminants of concern. There are vendors available with the necessary equipment and skilled workers to implement this technology. Bioremediation has been proven effective and reliable for destruction of petroleum hydrocarbons at similar sites. Capital costs would be low with very low to moderate O\&M.

\subsubsection{Disposal (Onsite/Ofisite)}

Disposal actions involve the preparation and transport of treated (treatment residual) and untreated waste. For disposal at a controlled landfill, TDEC requires that the treated waste TCLP extract for benzene and TPH not exceed $0.5 \mathrm{ppm}$ and $10.0 \mathrm{ppm}$, respectively. Untreated waste is excavated soil that will not be treated. Treated soils with suitable physical characteristics are considered for uncontrolled disposal by direct land application or as fill material. The waste materials are not considered to meet the definition of a RCRA hazardous waste. If the treated or untreated wastes are determined by the waste characterization study to be classified as RCRA hazardous waste, the disposal options will include disposal per RCRA regulatory requirements. The high effectiveness of all disposal options ensures the protection of human health and the environment.

Options for disposal include onsite and offsite options for treated and untreated soils. Onsite options for disposal are less costly than those for offsite due to lower transportation and disposal costs. Onsite controlled landfill costs are moderate to high and onsite uncontrolled land disposal costs are low to moderate. Disposal in the subject site excavation (if practical) provides the lowest cost option. Landfill capacity limitations and potential institutional factors may limit the use of onsite disposal. Currently, a ban exists prohibiting the offsite transport of wastes from ORR; therefore, offsite disposal is not a preferred disposal option. Offsite controlled landfill costs are high and offsite uncontrolled land disposal costs are moderate to high.

\subsubsection{Summary Of Top Three Selected Corrective Action Options}

The three corrective action options considered to be best for the specific petroleum contaminants at the Rust Garage Facility involve a combination of removal, treatment, and disposal general response actions. All of the corrective actions considered involve excavation of the contaminated soil prior to treatment. The treatment technologies are thermal desorption, solid-phase bioremediation, and soil washing.

Table 7-3 outlines specific requirements of the treatment technology associated with each of the selected corrective action options. The thermal desorption treatment technique is expected to result in a treated waste suitable for disposal at the Y-12 Centralized Landfill facility. Solidphase bioremediation is expected to allow unrestricted disposal, preferably with the treated soil remaining at the treatment site. The soil washing technique will generate two different waste streams requiring separate disposal.

\subsubsection{Advantages and Disadvantages}

Since the excavation technique will be the same regardless of the chosen treatment technology, the following discussion only addresses the advantages and disadvantages of the 
Table 7-3. Technology Specific Requirements of Top Three Corrective Action Options

\begin{tabular}{|c|c|c|c|}
\hline Requirement & Thermal Desorption & Soil Washing & Bioremediation \\
\hline $\begin{array}{l}\text { Water } \\
\text { Power } \\
\text { Fuel } \\
\text { Area (footprint) } \\
\text { Area (laydown) } \\
\text { \% Efficiency } \\
\text { Personnel Needs } \\
\text { Local Personnel } \\
\text { Equipment Needed } \\
\text { Time of Treatment } \\
\text { Treatability Study } \\
\text { Cost \$/yd } 3 \\
\text { Secondary Waste } \\
\text { Stream }\end{array}$ & $\begin{array}{l}20-100 \text { gpm } \\
480 \text { V } 600 \text { AMP } \\
\text { Propane } \\
150^{\prime} \times 130 \text { ' or less } \\
\text { Soil Pile } \\
99.9 \% \\
4-5 \\
70 \% \\
\text { Yes } \\
2-3 \text { months } \\
\text { Yes } \\
\$ 30-100\end{array}$ & $\begin{array}{l}200 \text { gpm } \\
150 \mathrm{KWH} \\
\text { None } \\
150 \text { ' } \times 200^{\prime} \\
\text { Incl. in footprint } \\
\text { Variable } \\
4-5 \\
90 \% \\
\text { Yes } \\
3 \text { months } \\
\text { Yes } \\
\$ 53-66\end{array}$ & $\begin{array}{l}\text { 0-20gpm } \\
120 \mathrm{~V} \\
\text { None } \\
140,000 \mathrm{ft}^{2} \\
\text { None } \\
99 \% \\
0-5 \\
90 \% \\
\text { No } \\
3-8 \text { months } \\
\text { Yes } \\
\$ 25-50\end{array}$ \\
\hline
\end{tabular}

This information was obtained by phone interview with technology vendors between March 17 and March 20, 1992. 
treatment technology and the final disposal requirement. The descriptions below are summarized in Table 7-4.

NOTE: Vendors of the remaining options were contacted and questioned using a standard list of requirements. The advantages and disadvantages were determined from the answers to these questions.

Thermal Desorption. Thermal desorption involves the destruction of all organic contaminants by heating above $200^{\circ} \mathrm{F}$. Thermal desorption physically separates volatile and some semivolatile contaminants from the contaminated soil. The thermal desorption process heats the contaminated media to between $200^{\circ}$ and $600^{\circ} \mathrm{F}$, driving off water and volatile contaminants. While there are several different types of combustors used in the process by different vendors, the main concept behind the technology is similar for them all. Soil is placed in the combustor where it is heated long enough to drive hydrocarbons from it. Dust from the exhaust is collected in a baghouse or scrubber and then joined with the treated waste stream. The hydrocarbons, in a vapor form, are either incinerated in a separate afterburner at a much higher temperature or are cooled to condense and reduce their volume and are adsorbed by carbon filters. The carbon filter air pollution control system generates a waste stream that requires additional treatment and/or disposal in a controlled landfill. Soil is separated as a clean product, and since the soil is still very hot and dusty, most systems water it for dust control, cooling, and to maintain soil workability. After confirmatory sampling, the soil is ready for use as fill material or landfill cover. The treated soil may be considered for uncontrolled disposal; however, the product from thermal desorption is considered a sterile product.

Mobile thermal desorption units capable of treating contaminated soil are commercially available for rental or purchase. Permitting and environmental impact considerations of this process, as well as site-specific considerations for mobilization, would have to be considered. A comprehensive treatability study would be conducted to define the operational parameters of this treatment option in relation to the contaminated soil. If the treatment is not meeting target concentrations, higher heat or longer exposure can be applied to complete the desorption. However, the clean-up efficiency of the process is very predictable at $99.9 \%$. The volume requiring treatment could be treated in approximately 2-3 months. The only waste streams created are an air discharge that can be monitored and permitted and carbon filter canisters that must be disposed of, if they are used.

Thermal desorption requires that treatment equipment be brought onsite. The $150^{\prime} \times 130^{\prime}$ area required for the equipment is the smallest area needed for any of the treatment options. This equipment does not require a great deal of room but runs the risk of radiological contamination. A concrete pad, or other suitable laydown area, is required to stockpile the soil before and after treatment. Personnel needs are 4 to 5 operators; 2 or 3 operators, or $70 \%$, can be from the local work force. The equipment requires 480 volts at 600 amps of operating power, a substantial amount of propane fuel, and 20-100 gpm of water to re-hydrate and cool the soil after desorption. Thermal desorption costs are high at $\$ 30-\$ 100 / \mathrm{yd}^{3}$.

Soil Washing. Soil washing is a water-based volume reduction process for treating contaminated soil after excavation. The objective of the process is to concentrate the contaminants into a smaller volume of material separate from the washed soil product. Soil washing can be used for contaminants associated with either fine size fraction of soil (silt, clay, and soil organic matter) or coarse fraction of soil (sand and gravel). The soil washing treatment process removes the contaminants from soils by dissolving or suspending the contaminants in the wash solution. The contaminated soil is mixed with water and subjected to an intensive mechanical scrubbing to remove the contaminants of concern with a water wash. This scrubbing action disintegrates soil particles, freeing contaminated fine particles from coarser sand and 
Table 7-4. Advantages and Disadvantages of Top Three

Corrective Action Options

\begin{tabular}{|c|c|c|}
\hline Technology & Advantages & Disadvantages \\
\hline Thermal Desorption & $\begin{array}{l}\text { - } 2-3 \text { months to complete } \\
\text { - No waste streams created } \\
\text { - 150' x } 130^{\prime} \text { area required } \\
\text { - Very predictable success }\end{array}$ & $\begin{array}{l}\text { - Equipment onsite } \\
\text { - High cost }\left(\$ 30-100 / \mathrm{yd}^{3}\right) \\
\text { - Sterile soil after } \\
\text { treatment } \\
\text { - Requires power, water } \\
\text { and fuel }\end{array}$ \\
\hline Soil Washing & $\begin{array}{l}\text { - } 3 \text { months to complete } \\
\text { - Moderate cost (\$53-66/yd }{ }^{3} \text { ) } \\
\text { - } 150^{\prime} \text { x } 200^{\prime} \text { area required } \\
\text { - Predictable success }\end{array}$ & $\begin{array}{l}\text { - Equipment onsite } \\
\text { - Soil is semi-sterile } \\
\text { after treatment } \\
\text { - Additional waste stream } \\
\text { created } \\
\text { - Requires power and water }\end{array}$ \\
\hline $\begin{array}{l}\text { Solid-Phase } \\
\text { Bioremediation }\end{array}$ & $\begin{array}{l}\text { - No equipment onsite } \\
\text { - Low cost }\left(\$ 25-50 / y^{3}\right)^{3} \\
\text { - Low utility requirements } \\
\text { - Fertile soil after treatment } \\
\text { - No waste streams created }\end{array}$ & $\begin{array}{l}\text { - } 3-8 \text { months to complete } \\
\text { - } 140,000 \mathrm{ft}^{2} \text { area } \\
\text { required } \\
\text { - Results not predictable } \\
\text { from treatability study }\end{array}$ \\
\hline
\end{tabular}


gravel. At this point the coarser particles are separated as cleaned product that is ready for uncontrolled disposal. Certain surfactants and/or chemical additions may be required to facilitate adequate removal of the petroleum hydrocarbons. Large volumes of wastewater would be generated and would require additional treatment prior to disposal or discharge. Gravity settlement of soils is used in the soil washing process to concentrate the soil contaminants in a smaller fraction of the volume (volume reduction). The concentrated portion of the waste stream, which makes up most of the soil, is expected to require further treatment. This treatment could be performed using thermal or bioremediation techniques at an offsite facility, or equipment could be brought onsite. After further treatment the concentrated soil could be ready for controlled disposal or uncontrolled disposal along with the washed product. The product of soil washing is sand and gravel, which will be relatively sterile and not suitable for plant rowth. Mixing with organics can make this product a usable soil.

A comprehensive treatability study would have to be conducted to define the operational parameters of this treatment option in relation to the contaminated soil. For the volume to be treated at Rust Garage, soil washing could be completed in approximately 3 months. Its cost is competitive at $\$ 53$ to $\$ 66 / \mathrm{yd}^{3}$; however, if secondary treatment is required, this cost could be much higher.

The equipment is mobile mounted and requires a relatively small area $\left(150^{\prime} \times 200^{\prime}\right)$ to operate. This area requirement includes a laydown area for handling the soils. Operating the equipment requires 4 to 5 personnel with up to $90 \%$ from the local work force. Treatment time can be predicted closely, and the efficiency, which varies, can be estimated by a scale test. Soil washing requires equipment to be brought onsite, introducing the risk of radiological contamination. The equipment for soil washing has a substantial electrical power drain of 150 kilowatt-hours and requires $200 \mathrm{gpm}$ of make-up water for the scrubbing process, but no additional fuel source.

Solid-Phase Bioremediation. Biological treatment of the excavated contaminated soil would involve aerobic degradation by a solid-phase bioremediation process. A bioaugmentation (addition of microorganisms) biological treatment process includes excavating the contaminated soil and transporting it to a designated location for biological treatment. The excavated soil is placed in a lined treatment bed or biological cell at a uniform depth where the bacteria and nutrients are applied. An aeration system to supply oxygen, and an aqueous nutrient addition system would be used. Aerobic biological degradation would provide for the complete destruction of the petroleum hydrocarbon contaminants upon completion of the treatment action. The remaining soil would be usable for uncontrolled disposal as fill material or for direct land application.

Aerobic bacteria are used to treat contaminants in solid-phase bioremediation. The end products of the biodegradation process are carbon dioxide, water, and bacterial biomass. The technology uses special strains of cultured bacteria and microorganisms naturally occurring in the soils and groundwater to break down the hydrocarbons. Solid-phase bioremediation is specifically tailored to site conditions. Soil conditions and contaminant types as well as treatment goals must be considered in decisions about what type of bacteria and nutrients to use, as well as with regard to the variables of $\mathrm{pH}$, temperature, and dissolved oxygen.

A comprehensive treatability study would be conducted to define the operational parameters of this treatment option in relation to the contaminated soil. The type of microbe, nutrient levels, oxygen addition, and expected time frame would be defined. 
The entire volume of soil treated by bioremediation would be eligible for uncontrolled disposal. The soil could be covered with topsoil and seeded where it was treated as a means of disposal. In any project on DOE properties in Oak Ridge there is a risk of radiological contamination to equipment. Solid-phase bioremediation does not require capital equipment to be brought onto the Y-12 reservation, eliminating risk of contamination. The process has a low utility requirement of 0 to $20 \mathrm{gpm}$ of water and $120 \mathrm{~V}$ electric power supply due to lack of large equipment needs. The area used for treatment will need to be periodically watered and tilled for aeration to create an ideal environment for the bacteria to break down the contamination. After the bacteria have broken down the contamination, they die; the soil is ready for uncontrolled disposal and may be fertile for growth. The process does not create additional waste streams while remediating the original contamination since collected leachate can be reapplied to the soil.

Solid-phase bioremediation is not totally predictable. The cost, and more importantly, the time required for treatment is not accurately known. The performance of the microorganisms is widely dependent on the soil conditions. Nutrients can be added to optimize their performance. Bioremediation is the slowest of the treatment options, requiring up to one year; however, most vendors indicate that the process could take as little as 2 months. For estimation purposes, the bioremediation process is expected to last 3 to 8 months. Bioremediation is the least expensive of the options at \$25-\$50/yd $\mathbf{d}^{3}$. Personnel needs range from five during treatment bed preparation to zero during the passive degradation process, with an average of $90 \%$ from the local work force.

A large, relatively level area of $140,000 \mathrm{ft}^{2}$ is required to construct the perimeter berms, place the liner, and spread the soil in a layer that may need to be as thin as $1 \mathrm{ft}$. No laydown area is required; however, other small areas will be needed for leachate collection, soil screening, and nutrient addition storage/mixing. As mentioned previously, there is a shortage of usable and available space at the Y-12 facility, and the National Environmental Policy Act (NEPA) requirement for an Environmental Assessment will require approximately two years for completion.

\subsubsection{Projected Remediation Periods}

Estimates of treatment time required were obtained through telephone conversations with technology vendors. It is estimated that approximately $4,524 \mathrm{yd}^{3}$ of soil will be excavated. Assuming a swell of $30 \%$ yields $5,881 \mathrm{yd}^{3}$ of loose soil. Time frames were obtained based on preliminary information; actual remediation time is expected to vary. All technologies have a common excavation time period. It is assumed that one month of excavation takes place before treatment begins. Excavation should proceed faster than any of the remediation options and will be able to run concurrently with soil decontamination. Excavation should take approximately 2 months for all corrective actions considered. Table 7-5 contains a summary of projected remediation periods.

Thermal Desorption. The $5,881 \mathrm{yd}^{3}$ of contaminated soil could be treated by thermal desorption in approximately 2 to 3 months. After treatment, it is expected to take approximately 1 month to dispose of the treated soils. The total remediation period is expected to last 4 to 5 months.

Soil Washing. Soil washing should take approximately 3 months. This does not include the additional treatment of the concentrated contamination, which could take an additional 2 to 3 months depending on the treatment alternative used. After treatment, it is expected to take approximately 1 month to dispose of the treated soils from both processes. The total remediation period is expected to last 6 to 7 months. 
Table 7.5. Projected Remediation Periods of Top Three

Corrective Action Options

\begin{tabular}{lllll}
\hline Treatment Technology & Excavation & Treatment & Disposal & Total Period \\
\hline Thermal Desorption & 1 month & $2-3$ months & 1 month & $3-4$ months \\
Soil Washing & 1 month & $5-6$ months & 1 month & $6-7$ months \\
Solid Phase Bioremediation & 1 month & $3-8$ months & 1 month & $4-9$ months \\
\hline
\end{tabular}

Note: Approximately 1 month of excavation should take place before beginning treatment; the second month can run concurrently with treatment. Disposal could also take place concurrently with treatment; however, the total period is conservatively assumed as cumulative time. 
Solid-Phase Bioremediation. Depending on climatic conditions, solid-phase bioremediation should take between 3 and 8 months. After treatment, it is expected that the soil could remain in place; therefore, the disposal period is null. Alternatively, decommissioning of the treatment cell, reapplication of the clean soil, and disposal of the liner should take less than 1 month. The total remediation period is expected to last 4 to 9 months. 


\subsection{CORRECTIVE ACTIONS CHOSEN}

\subsection{Soil Corrective Action}

\subsubsection{General Description of Soll Corrective Action}

Based on an evaluation of all criteria associated with the corrective action options discussed in Section 7.2, a combination of process options is proposed for the Rust Garage Facility. The proposed approach would initially involve initial excavation of contaminated soils from the impacted areas of the facility as identified in Section 5.3 of the Environmental Assessment Report for the Rust Garage Facility. The excavated soil would then undergo thermal desorption treatment, which would physically separate organic compounds from the soil matrix. The organic compounds would either be incinerated in an afterbumer unit or would be adsorbed by an activated carbon filter unit. The treated soils would finally be disposed by landfilling at a permitted Y-12 Plant facility, or used as fill material in the subject site excavation. A graphic illustration of the proposed corrective action is presented in Figure 8-1.

The corrective action approach proposed for the Rust Garage Facility offers several advantages over the other actions evaluated for the Corrective Action Plan. The proposed approach will result in removal of the facility TPH soil contamination source, human health and environmental concerns associated with implementation will be minimal, and the technical requirements associated with the approach will be manageable. The excavation and thermal desorption approach is also advantageous because the cleanup efficiency of this process is very predictable at $99.9 \%$. Thermal desorption has been proven effective and reliable at similar UST sites.

\subsubsection{Soil Remediation System Analysis}

\subsubsection{Soll Removal}

\section{Excavation}

Contaminated soils identified in excess of the $500 \mathrm{ppm}$ TDEC Closure Action Level for TPH at the Rust Garage Facility, and soils containing benzene, toluene, xylene (BTX) contamination in excess of $250 \mathrm{ppm}$, will be removed by excavation for the purpose of treatment and disposal. Delineation of soil contamination at the facility identified two areas of near-surface and subsurface contamination: a smaller area located at the former Building 9754-1 tank bay and a larger area extending south from Building 9720-15 (see Figure 5-10 of the Environmental Assessment Report).

Excavation beyond these delineated contamination areas may be required if additional contaminated soils are encountered as indicated by soil screening and/or sampling conducted during the excavation activities. Conversely, excavation of the entire delineated contamination area may not be required if sections of this area are determined to contain contaminants below the applicable TDEC Closure Action Levels. Excavation of the delineated contamination areas will be conducted as a phased approach such that excavation of one section of each area will be completed prior to the beginning of excavation of the next section. This is necessary to minimize disruption of on-going activities at the Rust Garage Facility and to ensure that only contaminated soil exceeding closure action levels are removed. Soil excavation will not extend significantly below the local water table since soils in this area would be considered part of the Y-12 Plant groundwater operable unit. 


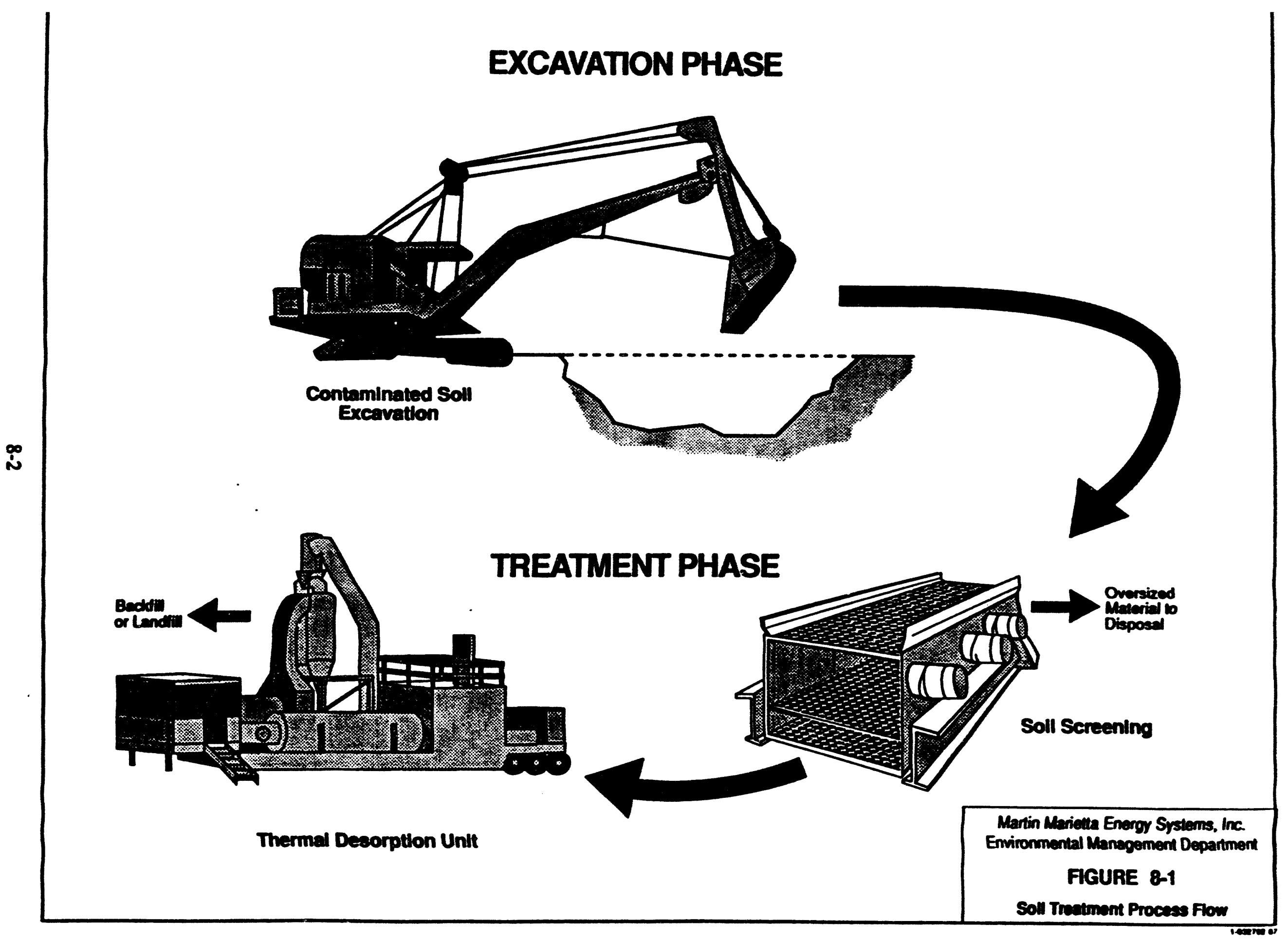


Prior to excavation activities, the excavation site will need to be cleared of fencing, minor structures, aboveground utilities, etc. The dismantling, removal, or relocation of any fencing, utility, or structure will be conducted under the direction of Martin Marietta Energy Systems, Inc. personnel. Surface control measures will be implemented to control surface water runon and runoff during excavation activities. Excavation of the contaminated soils will be accomplished using appropriate equipment provided by the Y-12 Plant Maintenance Department and/or a designated subcontractor. A large tracked excavator is planned to be used for the bulk of the excavation work due to the production capabilities and depth of excavation offered by this type of equipment. Utility lines will be protected during construction by preliminary location, bracing, and proper backfill upon refilling of excavations. If it is not possible to work around certain utilities, they will be either capped and removed, or re-routed, at the direction of Martin Marietta Energy Systems, Inc. personnel. Figure 2-3 presented in the Environmental Assessment Report shows approximate locations of suspected potable water, sanitary sewer, and storm drainage utilities in the planned areas of excavation.

\section{Soll Screening}

During the course of excavation activities, soil samples for field screening will be collected at multiple depth intervals between the surface and the water table. An average of one sample will be collected for every $250 \mathrm{ft}^{2}$ of excavated surface, and in any visibly contaminated areas of the excavation. A portion of each of the collected samples will be placed into an air-tight vial or sealable container and heated to a temporature of approximately $90^{\circ} \mathrm{C}$. A sample of the head space gas generated within the vial will then be extracted and analyzed using a portable gas chromatograph. An alternative that may be used in addition to head space analysis would involve field extraction of contaminants using a solvent and analysis of the extract using a portable gas chromatograph.

If the head space gas or extract derived from a soil sample is determined to contain greater than $500 \mathrm{ppm}$ TPH, or $250 \mathrm{ppm}$ BTX, excavation in the area from which the soil sample was collected wili continue until field screening analyses are below these levels. Head space screening will be conducted in accordance with Method ESP-303-7, Soil Gas Sampling (ESH/SUB/87-2706/1). Additionally, visual and odor observations may be used regarding the extent of soil excavation required when obvious contamination is encountered.

\section{Zone of Influence}

Figure 8-2 shows the areal extent of the contaminated soils proposed to undergo remediation. The larger contamination area is designated as Zone A and the smaller area as Zone B. A 2-ft buffer zone extending beyond the contaminated areas is assumed for excavation purposes. However, the entire area of Zone A or Zone B may not require excavation if field screening of soil samples indicate that sections of these zones are not contaminated in excess of closure action levels.

Excavation of Zone $\mathrm{A}$ is anticipated to encompass an areal extent measuring approximately $150 \mathrm{ft}$ by $165 \mathrm{ft}$ with excavation depths ranging from $6 \mathrm{ft}$ to $13 \mathrm{ft}$ below ground level. In the northern third of this excavation area, an average of the top $3 \mathrm{ft}$ of soil is expected to be noncontaminated pavement, base stone, and soil. The upper $0.5 \mathrm{ft}$ to $5.5 \mathrm{ft}$ of topsoil, rock, and gravel in the central third of the excavation area, and the upper $1.0 \mathrm{ft}$ to $4.5 \mathrm{ft}$ of soil and gravel in the southernmost portion of the excavation area, is expected to be noncontaminated. The upper material removed from the excavation area may be stockpiled and used for backfill after completion of removal activities, or disf. ssed of in the Y-12 Plant landfill. 


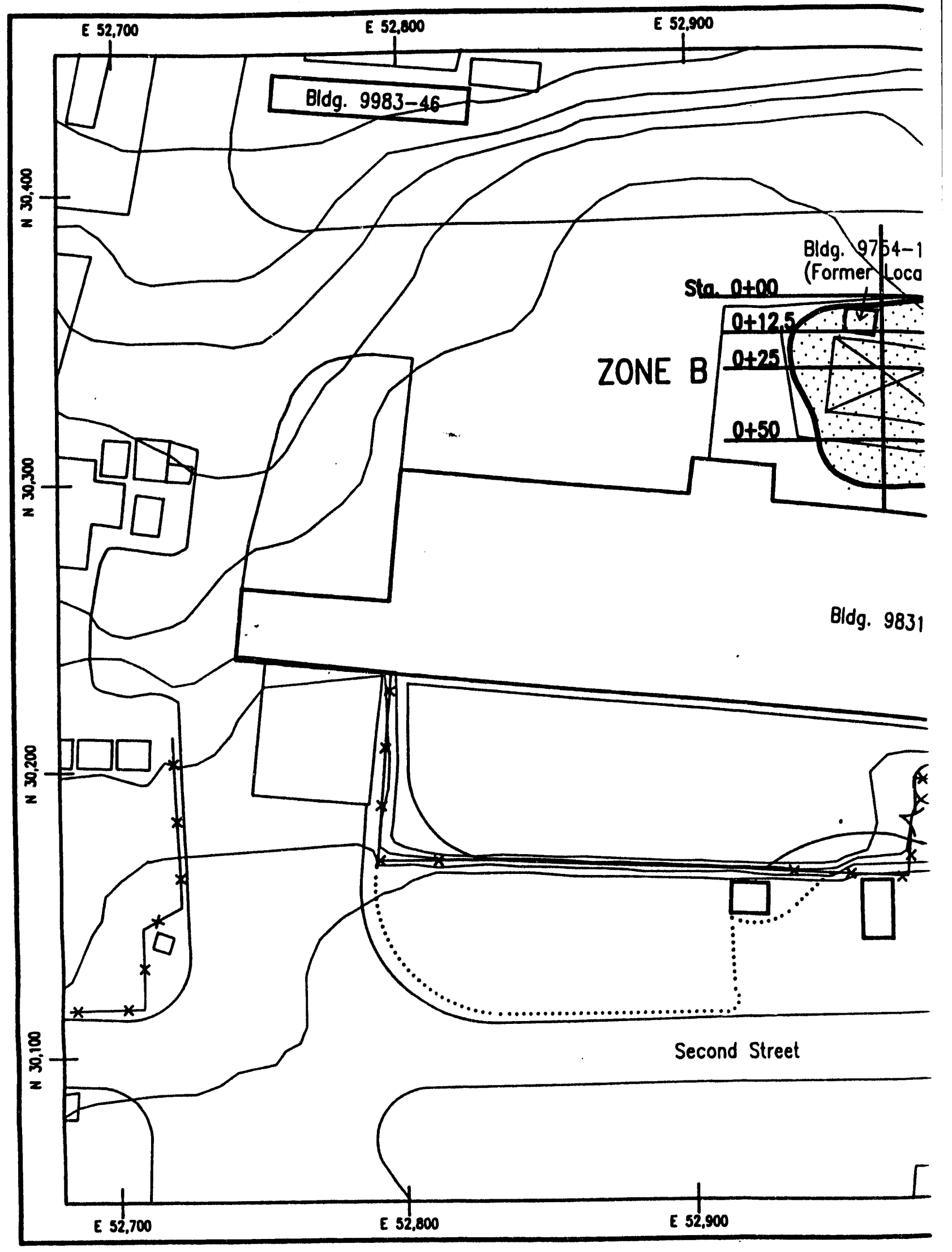

Nll locotion information presented in this figure is bosed upon MMES engineering drowings, results of previous MMES investigotions, ond/or field determinations of feature and sompling locotions. No representation or worranty, expressed or implied, is made os to the accuracy of the information or statements presented in this figure.

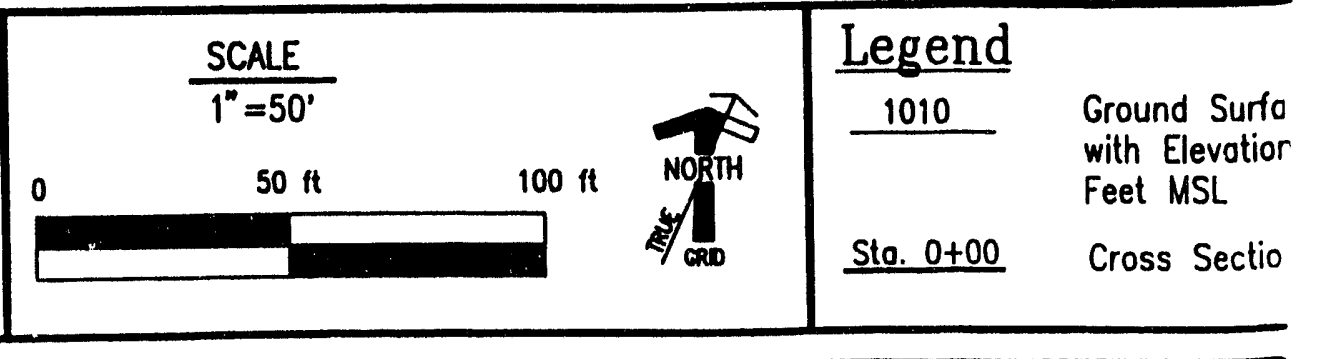




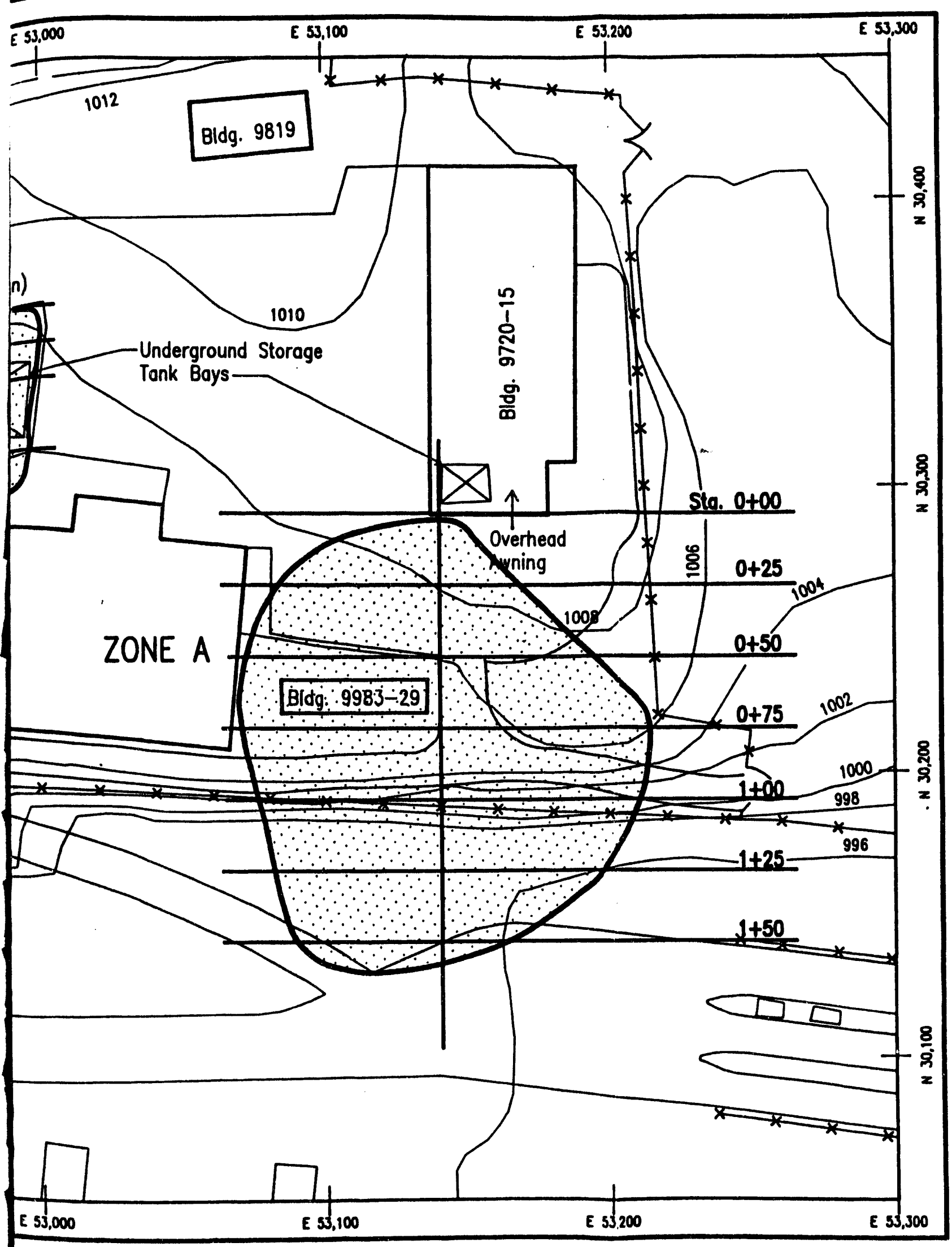

Contour line

Represented os

dentifier
Soil Contamination $>500$ ppm TPH
Martin Morietto Energy Systems, Inc. Environmental Manogement Department

$$
\text { FGURE 8-? }
$$

Rust Garage Facility Horizontal Zone of Influence Map 
Excavation of Zone $B$ is anticipated to encompass a basically rectangular area of approximately $75 \mathrm{ft}$ by $65 \mathrm{ft}$ within which soils would be removed to a depth of approximately 8.0 $\mathrm{ft}$ below ground level (Figure 8-2). The top $1.0 \mathrm{ft}$ of this excavation consists of gravel used in the original tank removal to refill the excavation and is not expected to exceed TDEC Closure Action Levels. This material may be used as backfill material or disposed of in the Y-12 Plant landfill.

The volumes of both zone excavations were calculated using the average end area method. Figure 8-2 indicates where the sections were established for this method calculations, and Figure 8-3 shows the actual cross-sections for Zones A and B.

Within Zone A, some asphalt pavement, gravel base, and soil material is assumed to be noncontaminated. The estimated depth of noncontaminated material is $3.0 \mathrm{ft}$ in the northernmost third of the excavation (sections $0+25$ and $0+50$ ), 0.5 to $5.5 \mathrm{ft}$ in the central portion of the excavation (sections $0+75$ and $1+00$ ), and 1.0 to $4.5 \mathrm{ft}$ in the southernmost portion of the excavation (sections $1+25$ and $1+50$ ). Because of seasonal variation of the local water table, the depth of contamination is assumed to extend approximately $1.0 \mathrm{ft}$ below the water table level noted on the cross-sections presented in Figure 8-3. The volume of contaminated soil to be excavated is expected to be approximately $3,700 \mathrm{yd}^{3}$ in place, or $4,850 \mathrm{yd}^{3}$ assuming a $30 \%$ swell factor. Table 8-1 contains the average end area calculations used to determine the volume of the excavation for Zone A.

Within Zone B, the top $1.0 \mathrm{ft}$ of the excavation is assumed to be noncontaminated gravel that was placed in the excavation during the original removal of the tanks previously located in the tank bay located in this zone. Because of seasonal variation of the local water table, the depth of contamination is assumed to extend approximately $1.0 \mathrm{ft}$ below the water table level noted on the cross-sections presented in Figure 8-3. The volume of contaminated soil to be excavated is expected to be approximately $800 \mathrm{yd}^{3}$ in place, or $1,050 \mathrm{yd}^{3}$ assuming a $30 \%$ swell factor. Table 8-1 contains the average end area calculations used to determine the volume of the excavation for Zone $B$.

The total volume of contaminated soil to be excavated at the Rust Garage Facility is expected to be approximately $4,500 \mathrm{yd}^{3}$ in place. Assuming $30 \%$ swell, the total volume of soil to be transported and treated is approximately $5,900 \mathrm{yd}^{3}$. However, the extent of contamination at the facility is based on field hydrogeologic information and sample analyses data generated from previous site investigations. Therefore, the final volume of soil requiring excavation will be dictated by subsurface conditions encountered during the course of excavation activities, and the results of field screening of soil samples collected during these activities.

\section{Confirmatory Sampling}

Upon completion of contaminated soil removal from the impacted areas of the Rust Garage Facility, confirmatory soil samples will be collected from excavation areas to ensure that this phase of the overall facility remediation is complete. The actual number and locations of the confirmatory samples to be collected will be dependent on the final areal extent and depth of the excavations and thus, will not be determined until all excavation activities are complete. It is anticipated that a minimum of eight confirmatory samples within Zone A, and a minimum of four confirmatory samples within Zone B, will be collected from the perimeter of the excavations and sent for laboratory analysis. The actual number of confirmatory samples collected from the excavation will be sufficient to demonstrate that all soil contamination above applicable TDEC Closure Action Levels has been removed. 


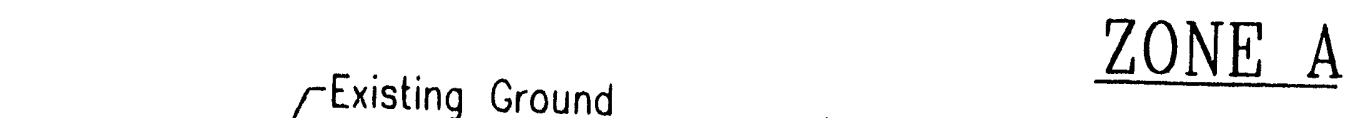

1010

Surface (Typical)

Area:

240 sq. ft.
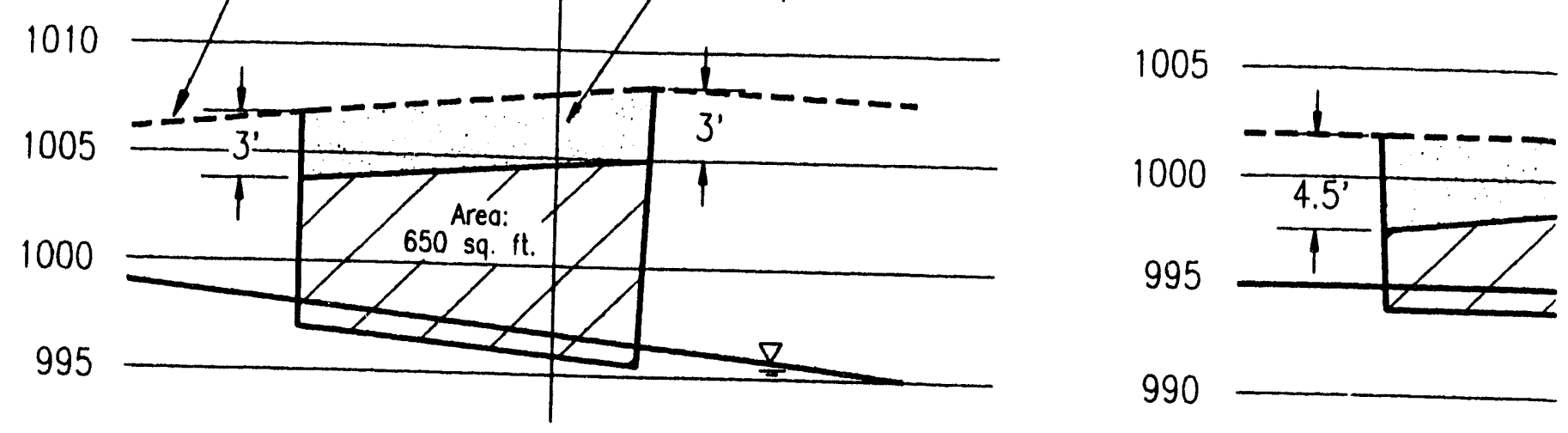

STA. $0+25$

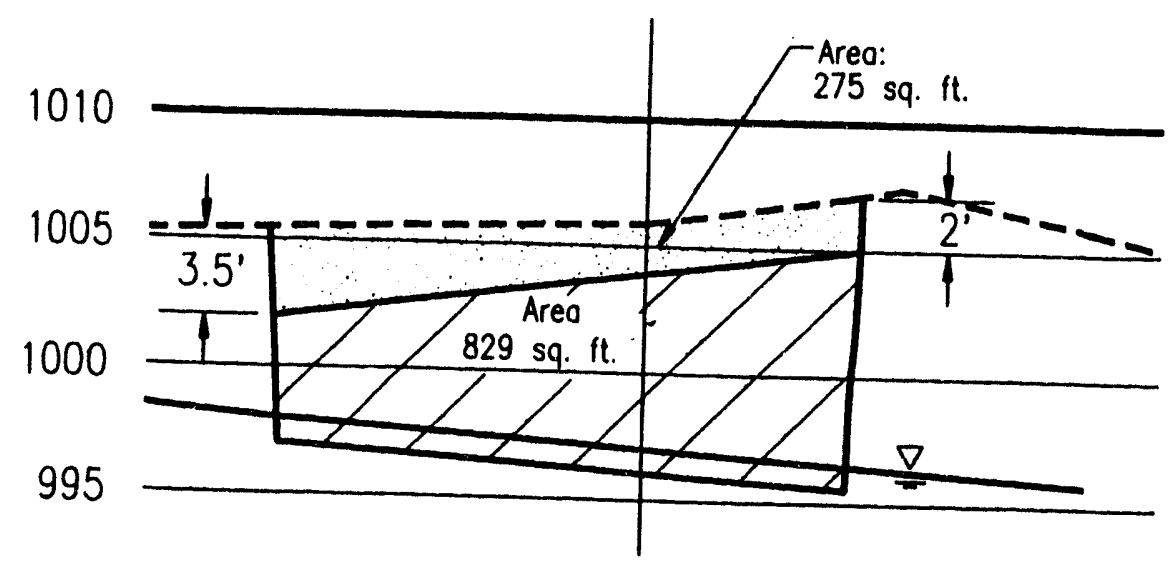

1000

990

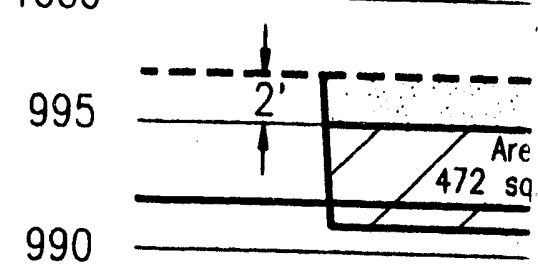

STA. $0+50$
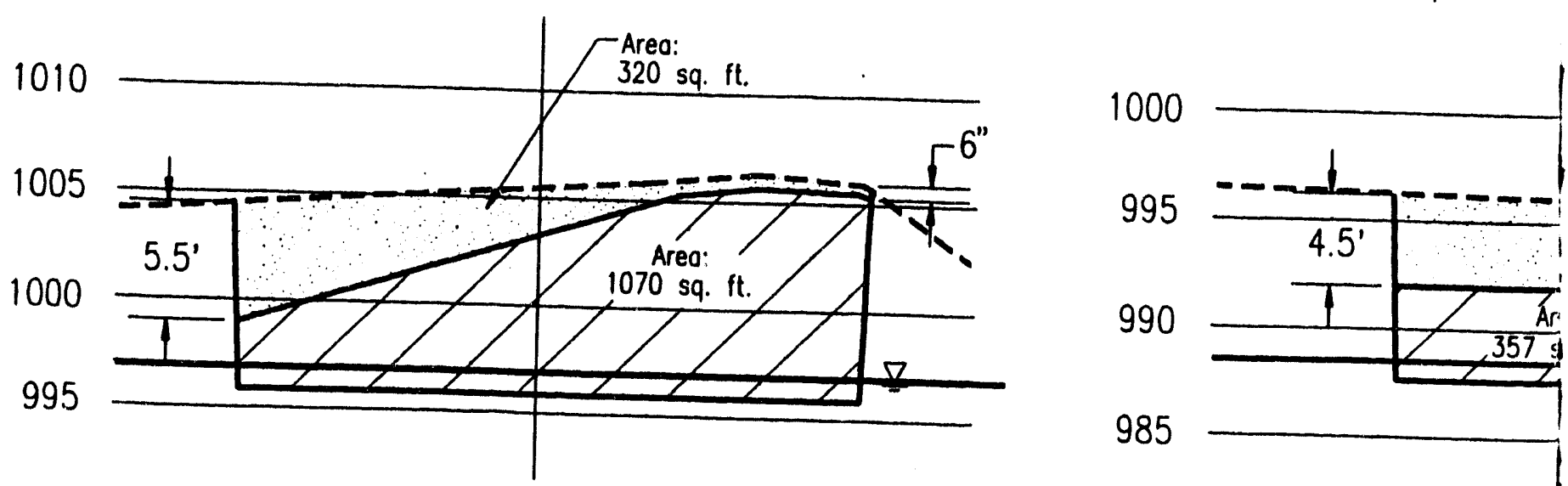

STA. $0+75$

All locotion information presented in this figure is based upon MMES engineering drowings, results of previous MMES investigations, and/or field determinations of feoture and sompling locations. No representotion or warronty, expressed or implied is made as to the occuracy of the information or stotements presented in this figure.
Horiz. Scale: $1^{\prime \prime}=50^{\prime}$

Vert. Scale: $1^{\prime \prime}=10^{\prime}$

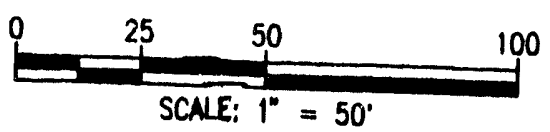

SCALE: $1^{\prime \prime}=50^{\circ}$
Legend

PA Contamination Zd To Be Excovoted Non-Contominate 


\section{ZONE B}

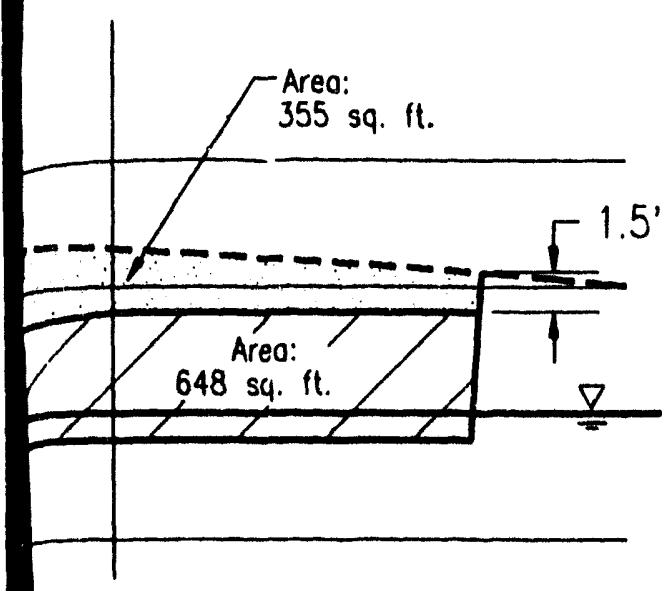

STA. $1+00$

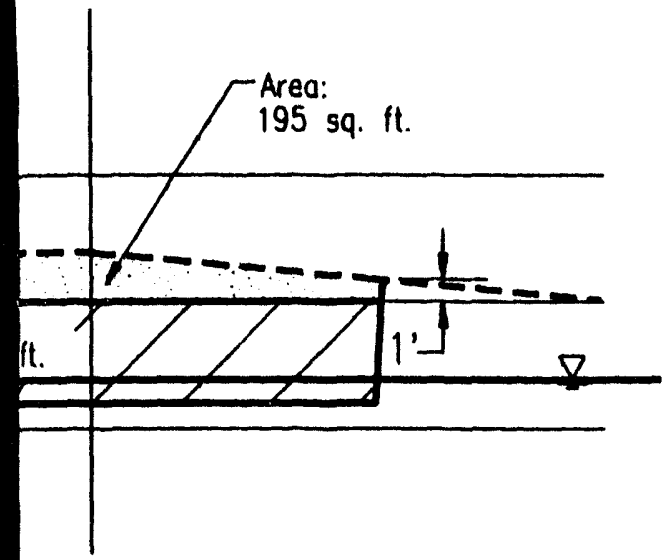

STA. $1+25$

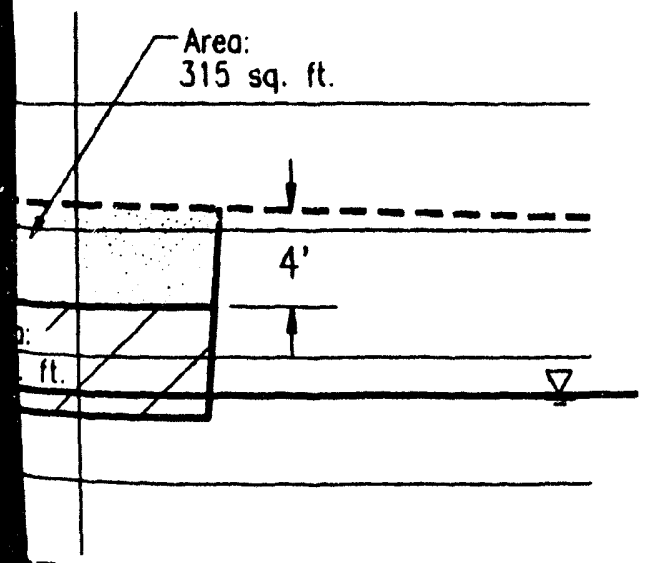

TA. $1+50$

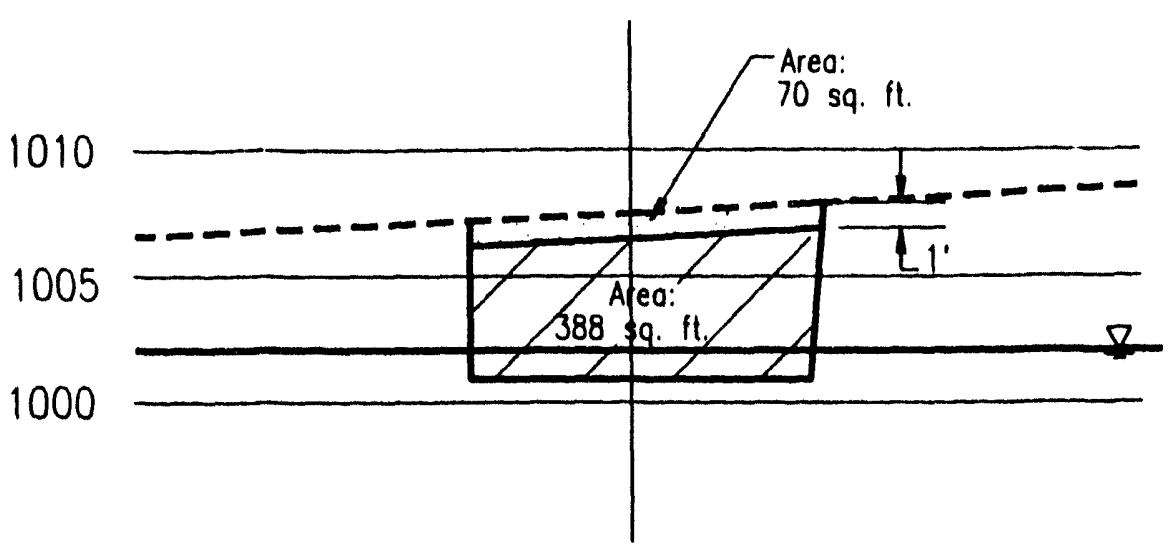

STA. $0+12.5$

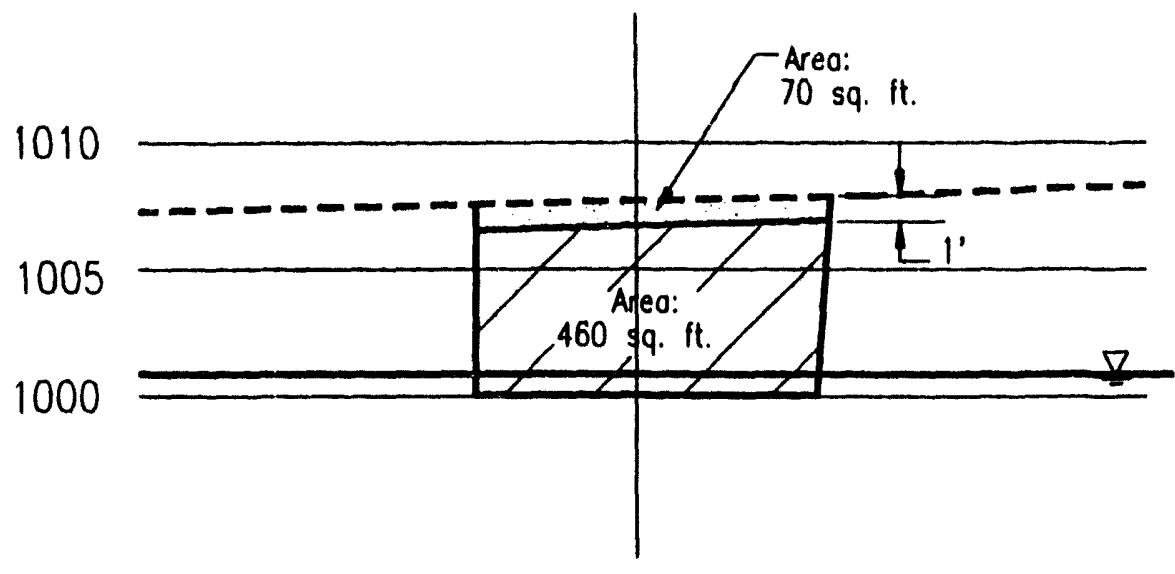

STA. $0+25$

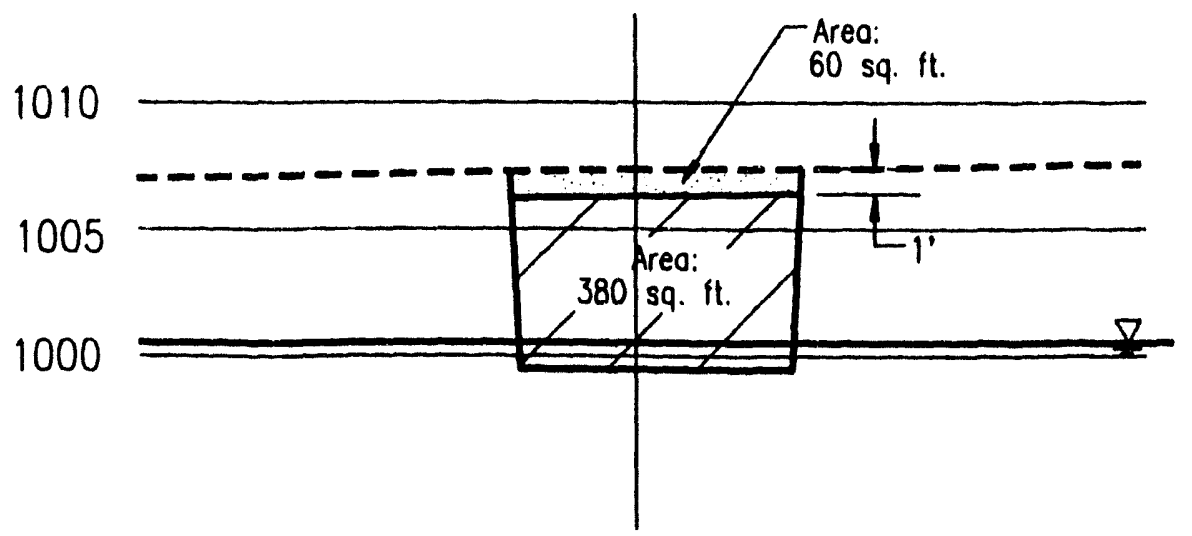

STA. $0+50$

Martin Marietta Energy Systems, Inc.

Environmental Manogement Deportment FIGURE 8-3

$\underline{\nabla} \quad$ Water Table

Rust Garage Facility Vertical Zone of Influence Map 
Table 8-1. Volume Calculation for Contaminated Soll at the Rust Garage Facility Based on Average End Area Method

\begin{tabular}{|c|c|c|c|c|c|c|c|}
\hline $\begin{array}{l}\text { Zone A } \\
\text { Station }\end{array}$ & $\begin{array}{l}\text { X-Section } \\
\text { Area } \\
\text { (contam) }\end{array}$ & $\begin{array}{l}\text { X.Section } \\
\text { Area } \\
\text { (noncontam) }\end{array}$ & $\begin{array}{l}\text { Avg. End } \\
\text { Area } \\
\text { (contam) }\end{array}$ & $\begin{array}{l}\text { Avg. End } \\
\text { Area } \\
\text { (noncontam) }\end{array}$ & Distance & $\begin{array}{c}\begin{array}{c}\text { Volume } \\
\text { yd } \\
\text { (contam) }\end{array} \\
\end{array}$ & $\begin{array}{c}\begin{array}{c}\text { Volume } \\
\text { yd }^{3} \\
\text { (nnncontam) }\end{array} \\
\end{array}$ \\
\hline \multirow[t]{2}{*}{0.0} & 0.0 & 0.0 & & & & & \\
\hline & & & 325.0 & 120.0 & 25.0 & 300.9 & 111.1 \\
\hline \multirow[t]{2}{*}{25.0} & 650.0 & 240.0 & & & & & \\
\hline & & & 739.5 & 257.5 & 25.0 & 684.7 & 238.4 \\
\hline \multirow[t]{2}{*}{50.0} & 829.0 & 275.0 & & & & & \\
\hline & & & 949.5 & 297.5 & 25.0 & 879.2 & 275.5 \\
\hline \multirow[t]{2}{*}{75.0} & 1070.0 & 320.0 & & & & & \\
\hline & & & 859.0 & 337.5 & 25.0 & 795.4 & 312.5 \\
\hline \multirow[t]{2}{*}{100.0} & 648.0 & 355.0 & & & & & \\
\hline & & & 560.0 & 275.0 & 25.0 & 518.5 & 254.6 \\
\hline \multirow[t]{2}{*}{125.0} & 472.0 & 195.0 & & & & & \\
\hline & & & 414.5 & 255.0 & 25.0 & 383.8 & 236.1 \\
\hline \multirow[t]{2}{*}{150.0} & 357.0 & 315.0 & & & & & \\
\hline & & & 178.5 & 157.5 & 25.0 & 165.3 & 145.8 \\
\hline \multirow[t]{2}{*}{175.0} & 0.0 & 0.0 & & & & & \\
\hline & & & & & Total Vol. & 3727.8 & 1574.0 \\
\hline \multicolumn{8}{|l|}{ Zone B } \\
\hline \multirow[t]{2}{*}{0.0} & 0.0 & 0.0 & & & & & \\
\hline & & & 178.8 & 35.0 & 12.5 & 82.8 & 16.2 \\
\hline \multirow[t]{2}{*}{12.5} & 388.0 & 70.0 & & & & & \\
\hline & & & 406.3 & 70.0 & 12.5 & 188.1 & 32.4 \\
\hline \multirow[t]{2}{*}{25.0} & 460.0 & 70.0 & & & & & \\
\hline & & & 397.5 & 65.0 & 25.0 & 368.1 & 60.2 \\
\hline \multirow[t]{2}{*}{50.0} & 380.0 & 60.0 & & & & & \\
\hline & & & 170.0 & 30.0 & 25.0 & 157.4 & 27.8 \\
\hline \multirow[t]{4}{*}{75.0} & 0.0 & 0.0 & & & & & \\
\hline & & & & & Total Vol. & 796.3 & 136.6 \\
\hline & & & & & Zone A+B & $4,524 y d^{3}$ & $1711 \mathrm{yd}^{3}$ \\
\hline & & & & & $+30 \%$ Swell & $5,881 y d^{3}$ & $2.224 \mathrm{yd}^{3}$ \\
\hline
\end{tabular}


A second type of confirmatory sampling to be conducted for this phase of the Rust Garage Facility remediation will involve collection of soil samples from excavated, noncontaminated material, which is segregated from soils designated for treatment. The purpose of this sampling will be to determine if the segregated material meets appropriate criteria for backfilling into the facility excavations or requires treatment via thermal desorption to reduce contaminant levels. The actual number of segregated material samples to be collected will be dependent on the final volume of material requiring disposal and, thus, will not be determined until all excavation activities are complete. However, a minimum of four composite samples, each comprised of four individual samples, will be collected from each $500 \mathrm{yd}^{3}$ volume of segregated material requiring disposal.

All confirmatory soil sampling will be conducted in accordance with Method ESP-303-1, Soil Sampling with a Spade and Scoop (ESH/SUB/87-2-706/1). Samples collected will be handled and preserved in accordance with Method ESP-701, Sample Preservation and Container Materials, and ESP-800, Packaging Environmental Samples for Transportation. All of the equipment used for sample collection will be decontaminated in accordance Method ESP-900, Cleaning and Decontaminating Sample Containers and Sampling Devices. Each of the excavation and segregated material soil samples collected will undergo laboratory analysis to determine the content of total BTX and TPH in accordance with the methodologies presented in Table 8-2. The segregated material samples will also undergo laboratory analysis for extractable lead because it was found to be present in soil samples collected at the Rust Garage Facility during previous site investigations. Several of these investigation samples contained sufficient concentrations of lead such that the soils represented by these samples may possibly exhibit hazardous characteristics.

In addition to the confirmatory soil samples, a complete set of Quality Assurance/Quality Control (QAVQ) samples will also be collected for this phase of the Rust Garage Facility remediation. The QAVC samples for the project will include duplicate soil samples to be collected along with the confirmatory samples, equipment rinsate samples to be collected on each day that sampling is conducted, and trip blank samples that will accompany each sample cooler transported to the analytical laboratory. The set of duplicate soil samples will represent no less than ten percent $(10 \%)$ of the total number of confirmatory samples collected. Each of the QAVQC samples will undergo the same types of laboratory analyses as the confirmatory samples. All QAVC activities and documentation will be performed in accordance with the current Y-12 Plant QAVQC program.

\subsubsection{Soil Treatment}

\section{Thermal Desorption}

The thermal desorption process will provide an ex situ means to physically separate volatile and some semivolatile contaminants from soil. The selected desorption unit will use either indirect or direct heat exchange to vaporize organic contaminants from soil. The thermal desorption process heats the contaminated media between $200^{\circ}$ and $600^{\circ} \mathrm{F}$, driving off water and organic contaminants. Air, combustion gas, or inert gas will serve as the transfer medium for the vaporized components. A baghouse or scrubber will collect the dust from the exhaust which is subsequently joined with the treated waste stream, or filtered out of the waste stream. Soil will be separated as a clean product and will be used as fill material in the Rust Garage Facility excavations, or landfilled at a permitted Y-12 Plant facility.

Contaminated soil material is removed from the Rust Garage Facility via excavation (as previously discussed) and delivered to the treatment unit. Typically, fill material objects (i.e., stones, brick, fragments, etc.) greater than 1.5 inches in size are removed from the contaminated soil material by mechanical screening prior to treatment. The soil material is then delivered by gravity to the desorber inlet, or conveyed by augers to a feed hopper. 
Table 8-2. Analytical Methods Proposed for Analyses of Remediation Soil and Samples Collected at the Rust Garage Facility

\begin{tabular}{lll}
\hline Contaminant $\quad$ Analytical Method $\quad$ Method Number \\
\hline
\end{tabular}

Confirmatory:

Volatile Organic Compounds (BTX)

Total Petroleum

Hydrocarbons

TPH-GRO/DRO

Lead

$$
\begin{aligned}
& \text { Gas Chromatography/ } \\
& \text { Mass Spectroscopy }
\end{aligned}
$$

Gas Chromatography/

Mass Spectroscopy

82401

Toxicity Characteristic

Leaching Procedure-Atomic Absorption

Flame Graphite Furnace Technique

\section{Post-Treatment:}

Volatile Organic Compounds (BTX)

$$
\begin{aligned}
& \text { Gas Chromatography/ } \\
& \text { Mass Spectroscopy }
\end{aligned}
$$

EPA 8015-

Modified2

$1311^{3 / 7421^{3}}$

Total Petroleum

Hydrocarbons

TPH-GRO/DRO

Lead

$$
\begin{aligned}
& \text { Gas Chromatography/ } \\
& \text { Mass Spectroscopy }
\end{aligned}
$$

EPA 8015-

Modified2

Toxicity Characteristic

Leaching Procedure-Atomic Absorption

Flame Graphite Fumace Technique
Waste Characterization:4 Benzene

Total Petroleum

Hydrocarbons
Toxicity Characteristic

Leaching Procedure-Fourier Transform Infrared Spectrometry

Toxicity Characteristic

Leaching Procedure-Fourier Transform Infrared Spectrometry

${ }^{4}$ Waste characterization only to occur if sanitary landfill disposal of soil is required.

SEPA, March 1983 
Thermal desorption treatment units vary greatly in the design of their heating component. The heating component may be an indirectly fired rotary kiln, a single (or set of) intermally heated screw auger(s), or a series of externally heated distillation chambers. The latter design uses annular augers to move the contaminated soil from one volatilization zone to the next. The contaminated soil is placed into contact with the heated surface, and organic components (including water) are driven off. Vaporized contaminants are removed from the heating unit using either an inert gas (such as nitrogen), which is injected in a countercurrent sweep stream, or by simply directing the hot gas stream from the unit.

The primary factors affecting performance in therral desorption include the actual bed temperature and residence time. Control of these parameters in the desorption unit is provided through use of a series of increasing temperature zones, multiple passes of the soil through the desorber where the operating temperature is sequentially increased, separate compartments where the heat transfer fluid temperature is higher, or sequential processing into higher temperature zones.

Organics in the offgas are burned in an afterburner, collected on activated carbon, or are recovered in condensation equipment. The carbon filter air pollution system generates a waste stream that requires additional treatment and/or disposal in a controlled landfill. The selection of the gas treatment system will be based on an evaluation of the concentrations of contaminants, cleanup standards, and the economics of the offgas treatment system(s) employed.

Regulatory and administrative controls will be taken into consideration with the implementation of this process. An evaluation of potential permit requirements and environmental impacts will be necessary. There are numerous vendors available with the necessary equipment and personnel to implement this technology. A mobile unit would be set-up within the Y-12 Plant. There would be no long-term management of residual contamination and/or untreated waste due to the removal of the contaminants and subsequent disposal. Operating costs will be moderate to high ranging from $\$ 30$ to $\$ 100 / \mathrm{yd}^{3}$.

The thermal desorption unit will be staged at an appropriate location within the Y-12 Plant site. A minimum area of $150 \mathrm{ft} \times 130 \mathrm{ft}$ will be necessary to accommodate the equipment. A suitable laydown area will be required to stockpile soil before and after treatment. The laydown area will be used to stockpile contaminated soil upon its excavation from the Rust Garage Facility. Four to five operators will be needed to operate the equipment that requires 480 volts at 600 amps of operating power, a substantial amount of propane fuel, and 20 to $100 \mathrm{gpm}$ of water to rehydrate and cool the soil after desorption treatment.

The excavation equipment may be operated simultaneously with the thermal desorption treatment unit, or excavation activities may be conducted prior to treatment if procurement of the desorption unit is not completed at the beginning of soil excavation. Operated simultaneously, an excavation rate of approximately $20 \mathrm{yd}^{3} / \mathrm{hr}$ would maximize the treatment production rate. This production rate is commensurate with the treatment rate of typical thermal desorption units. If excavation precedes treatment, soil material will be stockpiled during the course of excavation activities. Stockpiled material would be placed on plastic sheeting and covered to ensure that contamination of the storage site does not occur. Stockpiling of soil material would allow excavation activities to occur continuously through completion. $A$ front end loader would then be used to place contaminated soils into the treatment unit from the soil stockpiles.

\section{Post-Treatment Sampling}

During the course of the thermal desorption soil treatment phase of the corrective action, post-treatment soil samples will be collected for laboratory analysis. These samples will be used to 
monitor the effectiveness of petroleum contaminant removal within the thermal desorption unit. Remediation of the soils will be considered complete when the concentrations of total BTX and TPH have been reduced to levels less than or equal to $10.0 \mathrm{ppm}$ and $100.0 \mathrm{ppm}$, respectively.

Samples will be collected from soil stockpiles created as treated soil material exits the thermal desorption unit. Initially, the total volume of each stockpile (in cubic yards) will be determined. The total volume number will then be divided by fifteen and the resulting number will be multiplied by two. This calculated value will represent the number of soil samples that must be collected from a given stockpile for field screening analysis. These samples will be collected from points that evenly distributed throughout the entire volume of the soil, and will be representative of the total soil volume rather than the total area occupied by a given soil stockpile. The collected samples will undergo field head space gas screening using an organic vapor detector (OVD) or field gas chromatograph. Based on the results of the field screening, a minimum of two of the collected samples exhibiting the highest field screening readings will be submitted for laboratory analyses. In the event that the volume of a treated soil stockpile exceeds $240 \mathrm{yd}^{3}$, additional samples will be submitted for laboratory analyses in accordance with the requirements of the TDEC Technical Guidance Document - 005.

All post-treatment soil sampling will be conducted in accordance with Method ESP-303-1, Soil Sampling with a Spade and Scoop, or with a hand auger in accordance with Method ESP-303-2, Soil Sampling with an Auger (ESH/SUB/87-2-706/1). Samples collected will be handled and preserved in accordance with Method ESP-701, Sample Preservation and Container Materials, and ESP-800, Packaging Environmental Samples for Transportation. All of the equipment used for sample collection will be decontaminated in accordance with Method ESP-900. Cleaning and Decontaminating Sample Containers and Sampling Devices. Each of the posttreatment soil samples collected will undergo laboratory analysis to determine the content of total BTX, TPH, and extractable lead in accordance with the methodologies presented in Table 8-2. Extractable lead will be included in the analysis of the treated soil because it was found to be present in soil samples collected at the Rust Garage Facility during previous site investigations. Several of these samples contained sufficient concentrations of lead such that the soils represented by the samples may possibly exhibit hazardous characteristics.

In addition to the post-treatment soil samples, a complete set of QAVOC samples will also be collected for the post-treatment phase of the Rust Garage Facility remediation. The QAVQC samples for the project will include duplicate soil samples to be collected along with the posttreatment samples, equipment rinsate samples to be collected on each day that sampling is conducted, and trip blank samples that will accompany each sample cooler transported to the analytical laboratory. The set of duplicate soil samples will represent no less than ten percent $(10 \%)$ of the total number of post-treatment samples collected. Each of the QAVC samples will undergo the same types of laboratory analyses as the post-treatment samples. All QAVQ activities and documentation will be performed in accordance with the current Y-12 Plant QAVQC program.

\subsubsection{Soil Disposal}

Upon receipt of the analytical results for the treated soil stockpiles, this material will be transported back to the Rust Garage Facility for final disposal as backfill in the site excavations. In the event that the analytical results for any given soil stockpile indicate that the material contains contaminant levels in excess of TDEC Closure Action Levels (i.e., $10 \mathrm{ppm}$ total BTX and $100 \mathrm{ppm}$ TPH), the material will be re-introduced into the thermal desorption unit and treated for a second time. Treatment will continue until the contaminant levels within the material have been reduced to levels allowing for disposal as backfill at the Rust Garage Facility. Successful treatment of this material will be documented through re-sampling, which will be conducted in the same manner as the sampling of the original treated material. 
It is anticipated that near-surface soil overburden at the Rust Garage Facility will be noncontaminated material. This material will be stockpiled near the site excavations upon removal and sampled in the same manner as that described for the treated soil stockpiles. Based on the analytical results for the overburden material, it will either be placed into the site excavations as backfill material, or will be sent to the thermal desorption unit for treatment prior to being used as backfill at the site.

Soil material containing lead contamination at sufficient concentrations to warrant a hazardous classification, may possibly be encountered during the implementation of this corrective action plan. Any such soils would be segregated from nonhazardous soils upon completion of thermal desorption treatment. Hazardous waste generated from remediation activities would require temporary storage, and would eventually be transported to an appropriate disposal or treatment facility. However, based on preliminary analytical results with regard to lead concentrations derived from previous site investigations at the Rust Garage Facility, the volume of potential hazardous waste is expected to be minimal, or may not be present at all.

\subsection{Groundwater Corrective Action}

\subsubsection{Corrective Actions Considered}

Three groundwater corrective actions were considered to be appropriate for remediation of the Rust Garage Facility. These three corrective actions were (1) remediation under the Y-12 Plant CERCLA Program, (2) pump and haul, and (3) closed-loop circulation. The CERCLA Program option would involve remediation of the groundwater contamination at the Rust Garage Facility as part of the larger remedial action to be implemented for the Y-12 Plant Groundwater Operable Unit (Upper East Fork Poplar Creek - Operable Unit 1). This corrective action is proposed for remediation of groundwater at the Rust Garage Facility.

The pump and haul option would involve the extraction of contaminated groundwater using existing monitoring wells and/or new extraction wells installed at the facility. The extracted groundwater would then be transported to a Y-12 Plant wastewater treatment facility where it would undergo treatment and disposal through a National Pollutant Discharge Elimination System (NPDES) permitted outfall. This corrective action option was eliminated from consideration because the extracted groundwater would contain other contaminants (including trace metals, radionuclides, nitrates) not related to the Rust Garage Facility petroleum groundwater contamination. Treatment of this mixed waste would be difficult and costly to accomplish.

The closed-loop circulation option would involve the extraction of groundwater from the downgradient side of the facility, treatment of the groundwater using portable systems at the surface, and re-injection of the treated groundwater at the upgradient side of the facility. The portable treatment systems would consist of an air stripping unit and an activated carbon adsorption unit. The closed-loop circulation at the facility would continue until groundwater contaminant levels were reduced to below applicable TDEC Closure Action Levels. This corrective action option was eliminated from consideration because the extracted groundwater would contain other contaminants (including trace metals, radionuclides, nitrates) not related to the Rust Garage Facility petroleum groundwater contamination. The portable treatment systems could also become radiologically contaminated during operation with the activated carbon becming a secondary mixed waste. This action would result in the treatment of only petroleum product constituents rather than all of the groundwater contaminants present at the site. 
Based on an evaluation of all criteria associated with the corrective action options discussed above, remediation under the Y-12 Plant CERCLA Program is proposed as the corrective action option for petroleum-contaminated groundwater at the Rust Garage Facility. This selection is based upon the fact that petroleum groundwater plume at the Rust Garage Facility is comingled with contaminants associated with the S-3 Ponds groundwater plume. The S-3 Ponds plune is located throughout the west end of the Y-12 Plant and encompasses the entire Rust Garage Facility as illustrated in Section 4.2.2 of the Environmental Assessment Report for the Rust Garage Facility.

Remediation of groundwater petroleum contamination at the Rust Garage Facility will be addressed as part of remedial actions under CERCLA for the Y-12 Plant Groundwater Operable Unit. Remediation of the facility groundwater as part of the groundwater operable unit corrective action, rather than a separate action, will be more technically feasible and cost effective because large-scale treatment of multiple contaminants will be employed. Groundwater monitoring of the existing wells at the Rust Garage Facility will be conducted during development of remedial action plans for the groundwater operable unit in order to document changes in the nature and/or extent of the petroleum groundwater plume at the facility. In the event that free-product is discovered during implementation of the soil corrective action proposed for the Rust Garage Facility, removal of the free-product will be conducted in accordance with the requirements of TDEC Rules 1200-1-15-.05 and 1200-1-15-.06, and will not be addressed by the Y-12 Plant CERCLA Program.

With the inclusion of the Oak Ridge Reservation on the CERCLA National Priorities List, a Federal Facilities Agreement has been negotiated (effective date of January 1, 1992) which provides for the TDEC, U.S. Environmental Protection Agency, and DOE to proceed with CERCLA as the lead regulatory requirement, with the Resource Conservation and Recovery Act as an applicable or relevant and appropriate requirement. In line with a CERCLA remedial strategy, the Groundwater Operable Unit (Operable Unit 1) has been established separately fort the Upper East Fork Poplar Creek Hydrogeologic Regime. This approach is wartanted because: (1) efforts to establish the horizontal and vertical extent of groundwater contaminant plumes from individual sites indicates that the plumes are significantly comingled, making assessment and potential remedial actions of individual plumes impractical and (2) the units share a common exit pathway from the hydrologic system which is best addressed by a comprehensive approach. Additional justification for the selection of groundwater remediation at the Rust Garage Facility as part of the Y-12 Plant CERCLA Program is presented below.

\subsubsection{Description of the S-3 Ponds}

The S-3 Ponds are located about $200 \mathrm{ft}$ north of the headwaters of Bear Creek, near the topographic divide between Bear Creek and East Fork Poplar Creek. This site is part of the S-3 Waste Management Area which consists of the S-3 Ponds Hazardous Waste Disposal Unit, the S-2 Hazardous Waste Disposal Unit, the Interim Drum Yard, the Salvage Yard, the Rust Garage Facility, and four nonregulated solid waste management units. The locations of the various sites contained within the S-3 Waste Management Unit are presented in Figure 8-4.

The S-3 Ponds, built in 1951, consisted of four unlined impoundments covering an area of approximately $400 \times 400 \mathrm{ft}$. Designed to maximize rates of evaporation and percolation, the ponds were approximately $17 \mathrm{ft}$ deep and had a storage capacity of about 2.5 million gallons each. The original pond excavations penetrated weathered bedrock (residuum), but did not extend down to bedrock.

Waste products were discharged to the S-3 Ponds from 1951 to 1984 via tank trucks and an underground pipeline. They were primarily nitric acid, acid aluminum nitrate waste solutions, plating wastes, and miscellaneous liquid wastes associated with routine cleanup operations. Other 


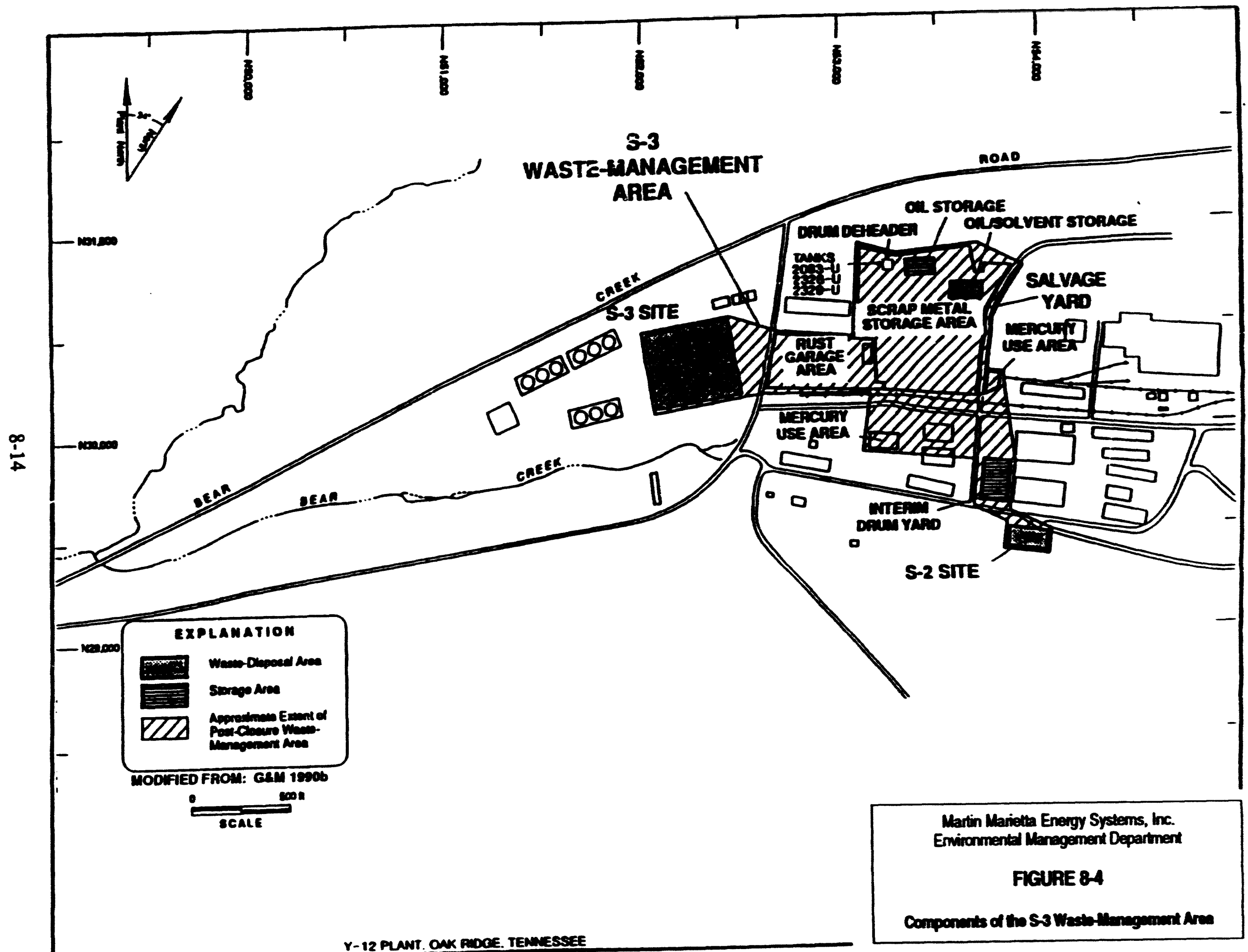


wastes placed into the ponds included dilute acid, machine coolants, caustic solutions, biodenitrification sludges, and concentrated nitric and other acids. During the mid-1950s, uranyl nitrate solutions containing small amounts of plutonium were disposed of at the ponds. Depleted uranium in nitric acid as well as technetium contained in raffinate and condensate may have entered the ponds during their operation.

\subsubsection{Nature and Extent of Groundwater Contamination}

The constituents of concern within groundwater in the Upper East Fork Poplar Creek Hydrogeologic Regime at the Y-12 Plant are trace metals, VOCs, nitrate, and radionuclides. The primary source of trace metals, nitrates, and radionuclides in the Upper East Fork Regime is the S3 Ponds site, which is also the main source of these contaminants in the Bear Creek Regime. Although the S-3 site lies west of a shallow groundwater divide that now separates the Bear Creek Regime from the East Fork Regime, a mound in the water table present below the site during its operational period enabled contaminants to migrate east of the current divide. Since waste disposal activities ceased at the S-3 site, the mound in the water table gradually abated and is no longer present.

Results of quarterly sampling conducted during 1992, and reported in the Y-12 Plant 1993 Groundwater Quality Assessment for the Bear Creek Hydrogeologic Regime, indicated that five individual trace metals associated with the S-3 Ponds site exceeded maximum contaminant levels for drinking water. During the 1992 quarterly sampling an additional nine trace metals associated with the S-3 site, and two radionuclides (strontium and uranium), were found to exceed screening levels. The screening level values represented the maximum total concentration that would be expected in uncontaminated, unfiltered groundwater samples collected from monitoring wells located upgradient from waste management sites at the Y-12 Plant. Nitrate at the site was found to be present at an average concentration of $3757.4 \mathrm{mg} / \mathrm{L}$, ranging up to a maximum concentration of $10955.0 \mathrm{mg} / \mathrm{L}$. A summary of the contaminants associated with the S-3 Ponds site as indicated by the 1992 quarterly sampling, and the range/average concentration of these contaminants, is presented in Table 8-3.

Results of quarterly sampling conducted during 1993, which will be reported in the Y-12 Plant 1994 Groundwater Quality Assessment for the Upper East Fork Poplar Creek Hydrogeologic Regime, indicated that the six groundwater monitoring wells located at the Rust Garage Facility (Wells 505, 508, 631, 632, 633, and 634) were contaminated with trace metals, radionuclides, and nitrates associated with the S-3 Ponds site (Figure 8-5). Average barium and chromium concentrations were found to exceed maximum contaminant levels at the facility while average cobalt, manganese, and strontium concentrations were found to exceed screening levels. At least one groundwater sample collected at the facility was found to contain aluminum, iron, zinc, and uranium concentrations in excess of screening levels. Nitrate at the facility was found to be present at an average concentration of $1144.4 \mathrm{mg} / \mathrm{L}$, ranging up to a maximum concentration of 5501.0 $\mathrm{mg} / \mathrm{L}$. A summary of the contaminants found to be present in the Rust Garage Facility monitoring wells as indicated by the 1993 quarterly sampling, and the range/average concentration of these contaminants, is presented in Table 8-4.

Based on the known presence of S-3 Ponds contaminants throughout the western portion of the Upper East Fork Regime, and the detection of a majority of these contaminants within the Rust Garage Facility monitoring wells, it is apparent that the S-3 groundwater plume encompasses the Rust Garage Facility site. Due to the comingling of S-3 contaminants with the petroleum contaminants originating at the Rust Garage Facility, separation of the petroleum contaminants for the purpose of groundwater remediation is not possible. Therefore, the best alternative with regard to remediation of contaminated groundwater at the facility would be a single remedial action under 
Table 8-3. Summary of S-3 Ponds Groundwater Quality Results Derived from 1992 Quarterly Groundwater Sampling at the Y-12 Plant

\begin{tabular}{llll}
\hline Contaminant & MCL & Min/Max & Average $^{3}$ \\
Barium & 1.0 & $4.8 / 340.0$ & 105.4 \\
Cadmium & 0.01 & $0.035 / 2.8$ & 1.25 \\
Chromium & 0.05 & $0.24 / 0.28$ & 0.26 \\
Lead & 0.05 & $0.067 / 0.067$ & 0.067 \\
Mercury & 0.002 & $0.053 / 0.11$ & 0.09 \\
Contaminant & $\mathrm{SL}^{4}$ & Min/Max & Average \\
Aluminum & 8.3 & $680.0 / 800.0$ & 730.0 \\
Beryllium & 0.0066 & $0.036 / 0.078$ & 0.06 \\
Boron & 1.1 & $1.4 / 2.1$ & 1.7 \\
Cobalt & 0.012 & $0.51 / 1.9$ & 1.3 \\
Copper & 0.44 & $0.46 / 1.4$ & 0.92 \\
Iron & 13.91 & $14.0 / 14.0$ & 14.0 \\
Manganese & 2.4 & $18.0 / 220.0$ & 114.7 \\
Nickel & 0.18 & $15.0 / 20.0$ & 17.7 \\
Zinc & 0.14 & $0.17 / 4.0$ & 1.8 \\
Strontium & 0.88 & $11.0 / 320.0$ & 100.6 \\
Uranium & 0.01 & $0.37 / 36.0$ & 7.7 \\
Nitrate Nitrogen & $\mathrm{NA}$ & $11.0 / 10955.0$ & 3757.4 \\
\hline
\end{tabular}

${ }^{1} \mathrm{MCL}$ - Maximum Contaminant Limit (mg/L).

${ }^{2} \mathrm{Min} / \mathrm{Max}$ - minimum and maximum concentrations $(\mathrm{mg} / \mathrm{L})$ detected in quarterly groundwater samples collected during 1992 from

the S-3 Ponds area.

${ }^{3}$ Average - calculated average of all concentrations ( $\mathrm{mg} / \mathrm{L}$ ) detected in quarterly groundwater samples collected during 1992 from the S-3 Ponds area.

${ }^{4} \mathrm{SL}$ - Screening Level $(\mathrm{m} / \mathrm{L})$. Value represents the maximum total concentration that would be expected in uncontaminated, unfiltered groundwater samples collected from monitoring wells located upgradient from waste management sites at the Y-12 Plant. 


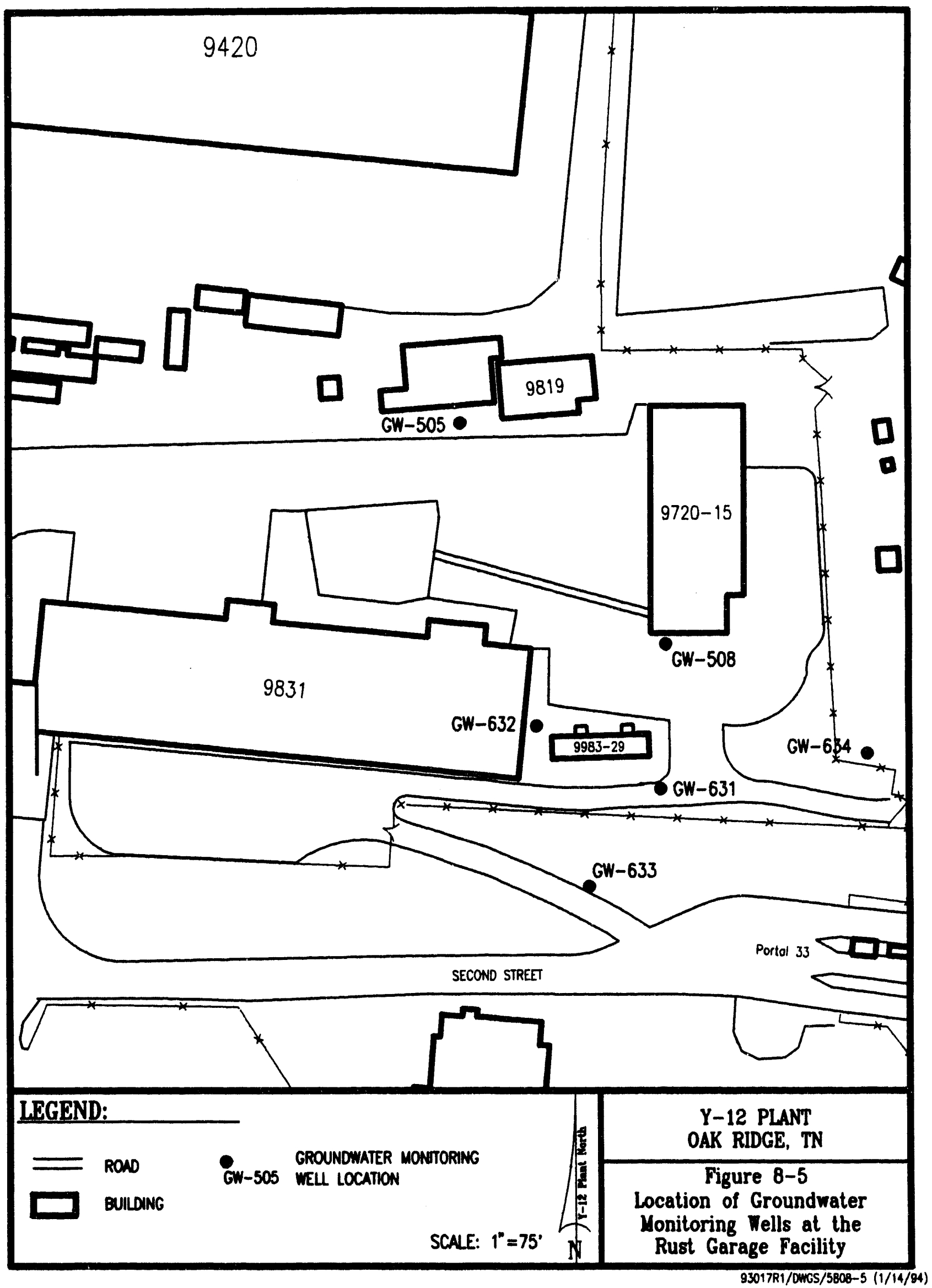




\section{Table 8-4. Summary of Rust Garage Facility Groundwater Quality Results Derived from 1993 Quarterly Groundwater Sampling at the Y-12 Plant}

\begin{tabular}{|c|c|c|c|c|}
\hline Contaminant & $\mathrm{MCL}^{1}$ & $\operatorname{Min} / \operatorname{Max}^{2}$ & Average 3 & Wells Contaminated \\
\hline Barium & 1.0 & $0.063 / 33.0$ & 4.45 & $\begin{array}{l}505,508,631,632,633, \\
634\end{array}$ \\
\hline Cadmium & 0.01 & $0.0056 / 0.0063$ & 0.0059 & 505 \\
\hline Chromium & 0.05 & $0.019 / 0.48$ & 0.14 & 505,632 \\
\hline Lead & 0.05 & $\mathrm{ND}^{4}$ & ND & $\mathrm{NA}^{5}$ \\
\hline Mercury & 0.002 & $0.00022 / 0.00023$ & 0.000225 & 508,631 \\
\hline Contaminant & $S^{6}$ & MinMax & Average & Wells Contaminated \\
\hline Aluminum & 8.3 & $0.056 / 11.0$ & 2.74 & $\begin{array}{l}505,508,631,632,633, \\
634\end{array}$ \\
\hline Beryllium & 0.0066 & $0.00043 / 0.0042$ & 0.0013 & $505,508,631,632,634$ \\
\hline Boron & 1.1 & $0.025 / 0.22$ & 0.060 & $\begin{array}{l}505,508,631,632,633, \\
634\end{array}$ \\
\hline Cobalt & 0.012 & $0.0074 / 0.22$ & 0.073 & $505,508,631,632,634$ \\
\hline Copper & 0.44 & $0.0051 / 0.011$ & 0.0076 & $505,508,631,632$ \\
\hline Iron & 13.91 & $0.040 / 14.0$ & 3.05 & $\begin{array}{l}505,508,631,632,633, \\
634\end{array}$ \\
\hline Manganese & 2.4 & $0.37 / 11.0$ & 3.92 & $\begin{array}{l}505,508,631,632,633, \\
634\end{array}$ \\
\hline Nickel & 0.18 & $0.019 / 0.12$ & 0.05 & $505,508,631,632,634$ \\
\hline Zinc & 0.14 & $0.018 / 0.15$ & 0.062 & $\begin{array}{l}505,508,631,632,633, \\
634\end{array}$ \\
\hline Strontium & 0.88 & $0.011 / 15.0$ & 2.10 & $\begin{array}{l}505,508,631,632,633, \\
634\end{array}$ \\
\hline Uranium & 0.01 & $0.002 / 0.012$ & 0.006 & 505,633 \\
\hline Nitrate Nitrogen & NA & $1.0 / 5501.0$ & 1144.4 & $505,631,632,633$ \\
\hline
\end{tabular}

${ }^{1} \mathrm{MCL}$ - Maximum Contaminant Limit (mg/L).

${ }^{2} \mathrm{Min} / \mathrm{Max}$ - minimum an maximum concentrations (mg/L) detected in quarterly groundwater samples collected during 1993 from the Rust Garage Facility.

${ }^{3}$ Average - calculated average of all concentrations $(\mathrm{mg} / \mathrm{L})$ detected in quarterly groundwater samples collected during 1993 from the Rust Garage Facility.

${ }^{4} \mathrm{ND}$ - contaminant not detected in quarterly groundwater samples collected during 1993 from the Rust Garage Facility.

5NA - not applicable.

${ }^{6} \mathrm{SL}$ - Screening Level (mg/L). Value represents the maximum total concentration that would be expected in uncontaminated, unfiltered groundwater samples collected from monitoring wells located upgradient from waste management sites at the Y-12 Plant. 
future CERCLA activities for the Y-12 Plant groundwater operable unit, which would address all of the types of groundwater contaminants present at the Rust Garage Facility.

\subsubsection{Integration of UST and CERCLA Requirements}

UST requirements will be integrated into the Y-12 Plant CERCLA Program with regard to remediation of groundwater at the Rust Garage Facility. This integration will include the following: (1) inclusion of all applicable UST parameters as applicable or relevant and appropriate requirements in CERCLA characterization and sampling activities and (2) inclusion of all applicable UST parameters in the risk assessment performed for Operable Unit 1 . In the event that remediation of groundwater is determined to be appropriate, all applicable petroleum contaminants will be taken into consideration during the evaluation and selection of treatment technologies. The TDEC DOE-Oversight Office (UST personnel) will be apprised of CERCLA developments, including participation in meetings and/or review of documents applicable to Operable Unit 1. 


\subsection{PROPOSED IMPLEMENTATION SCHEDULE}

This section presents the schedule proposed for the activities and reporting associated with implementation of the chosen soil corrective actions for the Rust Garage Facility. A general schedule for the CERCLA remedial actions involving the Y-12 Plant Groundwater Operable Unit which includes the Rust Garage Facility is also presented.

\subsection{Soil Corrective Action Schedule}

The proposed schedule for soil corrective actions at the Rust Garage Facility is as follows:

Activity

Issue Original CAP

Issue CAP Addendum

TDEC Approval of CAP Addendum

Issue Bid Specifications for

Excavation and Treatment Activities

Begin Excavation Preparation

Issue First Monthly Report on Progress

and Field Screening/Sampling Results

Begin Soil Treatment

Issue Second and Third Monthly Reports on

Progress and Field Screening/Sampling Results

Issue Quarterly Reports on Progress and

Soil Treatment Sampling Results

Issue final Corrective Action Report (CAR)
Target Date

May 1992

January 1994

....pending....

Within 90 days of CAP Addendum approval

Within 30 days of contract award

Within $\mathbf{4 5}$ days of excavation start

Within $\mathbf{4 5}$ days of contract award

Within 30 days and 60 days of the first monthly report

Within 90 days of third monthly report and every 90 days for subsequent quarterly reports as long as soil remediation activities are in progress

Within 90 days of the completion of all soil remediation activities and receipt of all sampling analysis results

\subsection{Groundwater Corrective Action Schedule}

The current schedule for the CERCLA remedial actions involving the Y-12 Plant Groundwater Operable Unit (OU 1), including the Rust Garage Facility, is presented in Appendix $A$ of this addendum. 


\subsection{MONITORING AND REPORTING}

\subsection{Soll Corrective Action}

\subsubsection{Monthly and Quarterly Reports}

Monthly progress reports for the first three (3) month period during which soil corrective actions are implemented at the Rust Garage Facility will be completed and sent to the appropriate TDEC offices, detailing applicable information required by the Corrective Action Plan Guidelines. These reports will be submitted by the fifteenth (15th) day of each subsequent month within the initial three month reporting period.

Quarterly progress reports regarding soil corrective actions will be submitted after the initial three month reporting period. These reports will be submitted within fifteen (15) days of the end of each reporting quarter and will continue for the duration of the soil corrective action process. At a minimum, the monthly and quarterly reports will contain the following information:

- General description of the progress or completion of soll corrective action activities to date.

- Analytical results for field screening and confirmatory soil samples collected during the course of excavation activities.

- Analytical results for post-treatment soil samples collected during the course of thermal desorption treatment.

- General description of any problems encountered with the soil corrective action systems since the previous reporting period and the actions undertaken to resolve these problems.

\subsubsection{Corrective Action Report}

A CAR for the Rust Garage Facility will be prepared upon completion of all soil remediation activities. This report will include the following information:

- Description of excavation activities conducted at the site and confirmatory soil sampling performed within excavation areas.

- Description of the thermal desorption treatment system used for remediation of petroleum contaminated soil.

- Description of all disposal actions regarding treated soil.

- Analytical results reported for confirmatory and post-treatment soil samples collected during the course of remediation.

- Conclusions regarding the effectiveness of all soil corrective actions implemented at the site.

\subsection{Groundwater Corrective Actions}

Quarterly sampling for various groundwater contaminants, including petroleum product constituents, will be conducted by the Y-12 Plant from the monitoring wells located at the Rust Garage Facility. Results and interpretations related to this sampling will be reported annually in the Y-12 Plant Groundwater Quality Assessment for the Upper East Fork Poplar Creek Hydrogeologic 
Regime. Reports concerning the progress of CERCLA groundwater remedial actions at the Rust Garage Facility will be issued by the Y-12 Plant Environmental Restoration Program. The TDEC DOE-Oversight Office will be sent copies of all reports pertaining to groundwater monitoring and CERCLA actions at the Rust Garage Facility by the program or organization responsible for the development of these reports. The Y-12 Plant UST Program will not be responsible for the performance of monitoring, or reporting on remediation progress, with regard to groundwater at the Rust Garage Facility. 
HEALTH, SAFETY, ENVIRONMENT, AND ACCOUNTABILITY ORGANIZATION

D.E. Bohrman (2)

L.L. Cunningham/E.M. Ingram

L.W. McMahon

Flle - EMD - RC

ENVIRONMENTAL RESTORATION ORGANIZATION

C.G. Hudson

K.M. Nelson

C.M. Smith

ENVIRONMENTAL COMPLIANCE

ORGANIZATION

S.H. Welch

TENNESSEE DEPARTMENT OF ENVIRONMENT AND CONSERVATION

C. Head

E.C. Leming/J.D. Harless

CENTRAL ENGINEERING

SERVICES ORGANIZATION

T.J. Pierce

\section{U.S. DEPARTMENT OF ENERGY}

E.M. Atkins

R.J. Spence/W.G. McMillian

S.R. Lankford
A.K. Lee/DOE-OSTI (2)

Y-12 Central Files

M.K. FERGUSON

J.H. Darden

L.R. Roddy 


\section{Appendix A}

CERCLA Schedule for the Y-12 Plant

Groundwater Operable Unit (OU1) 


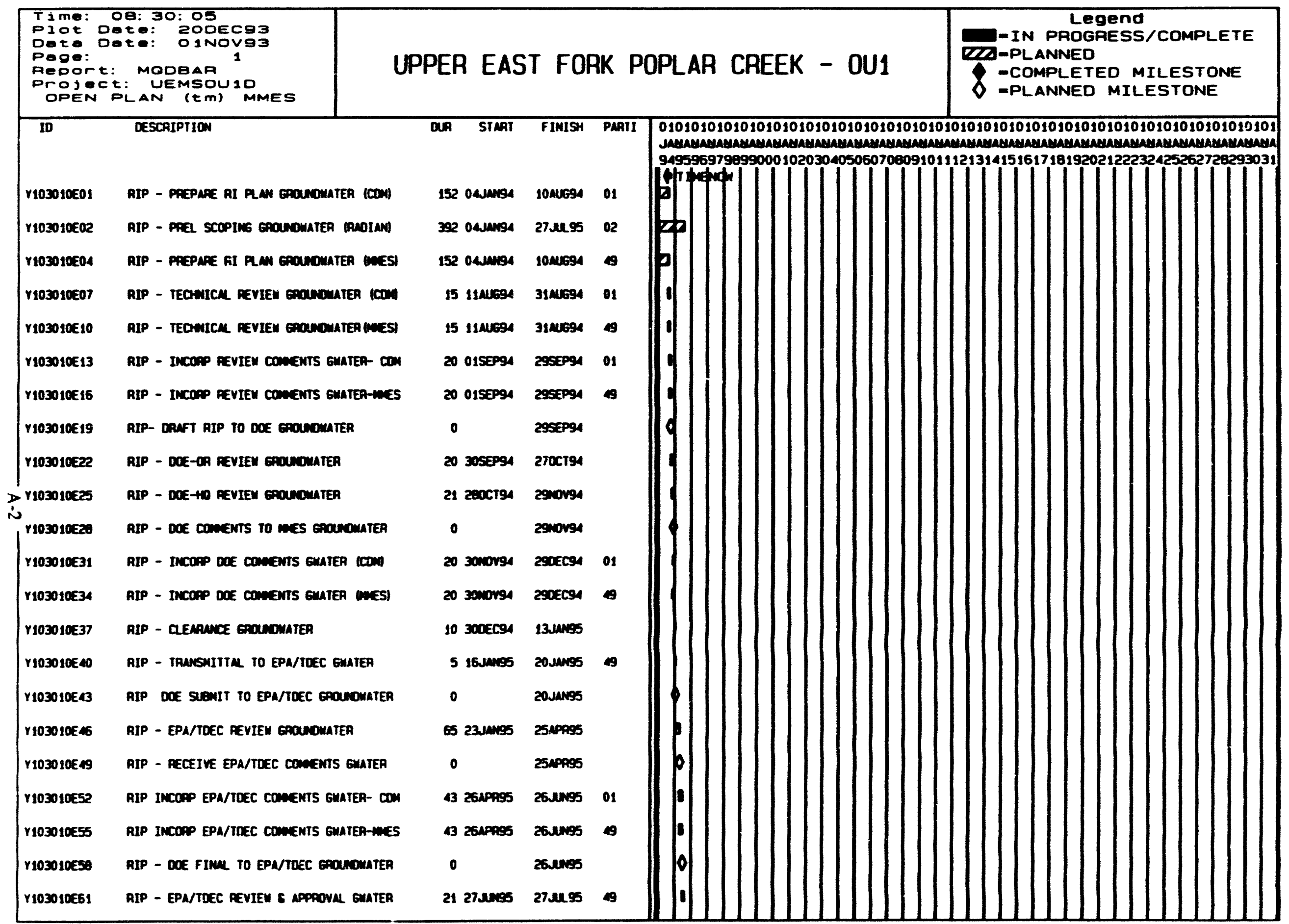




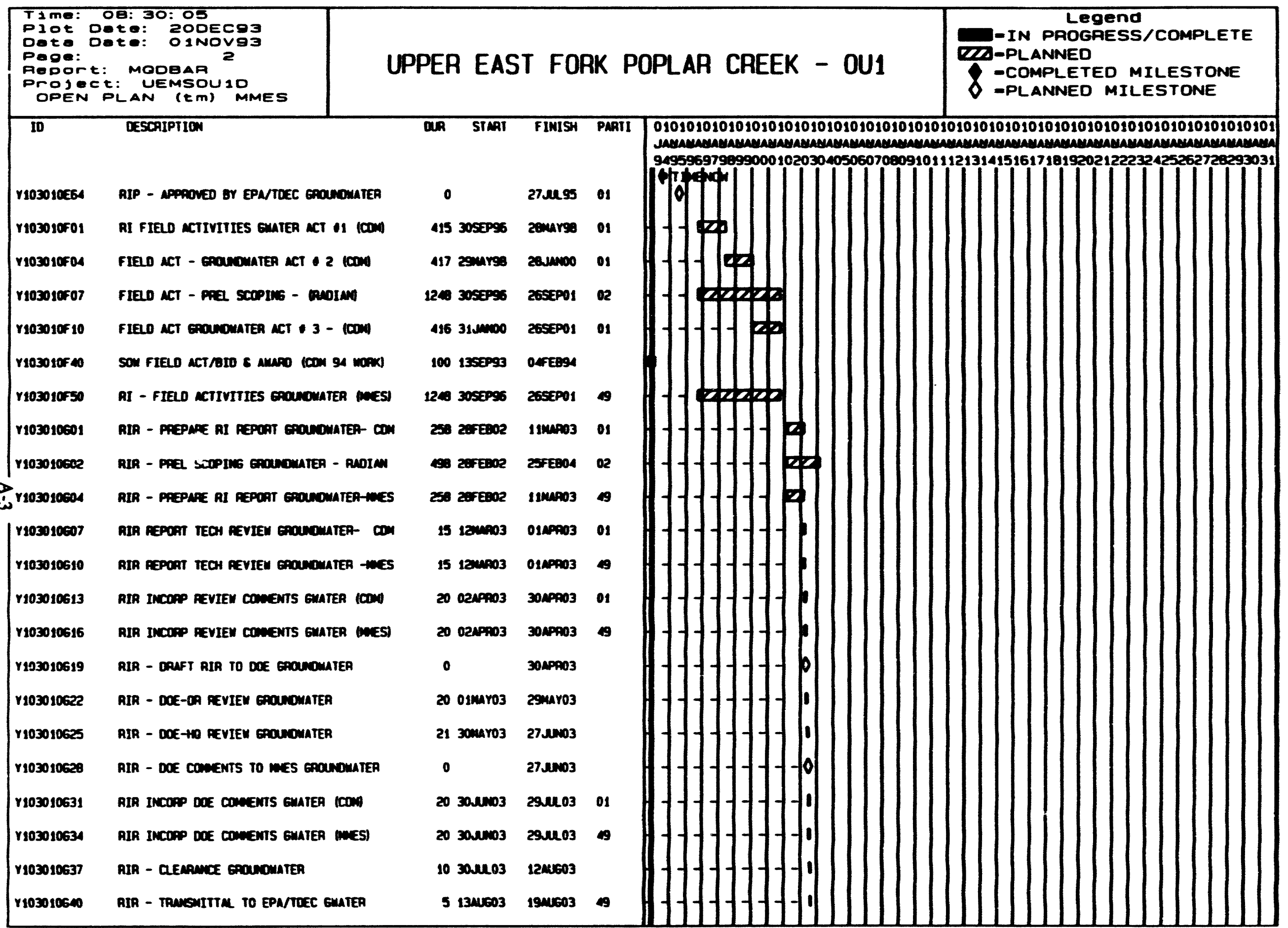




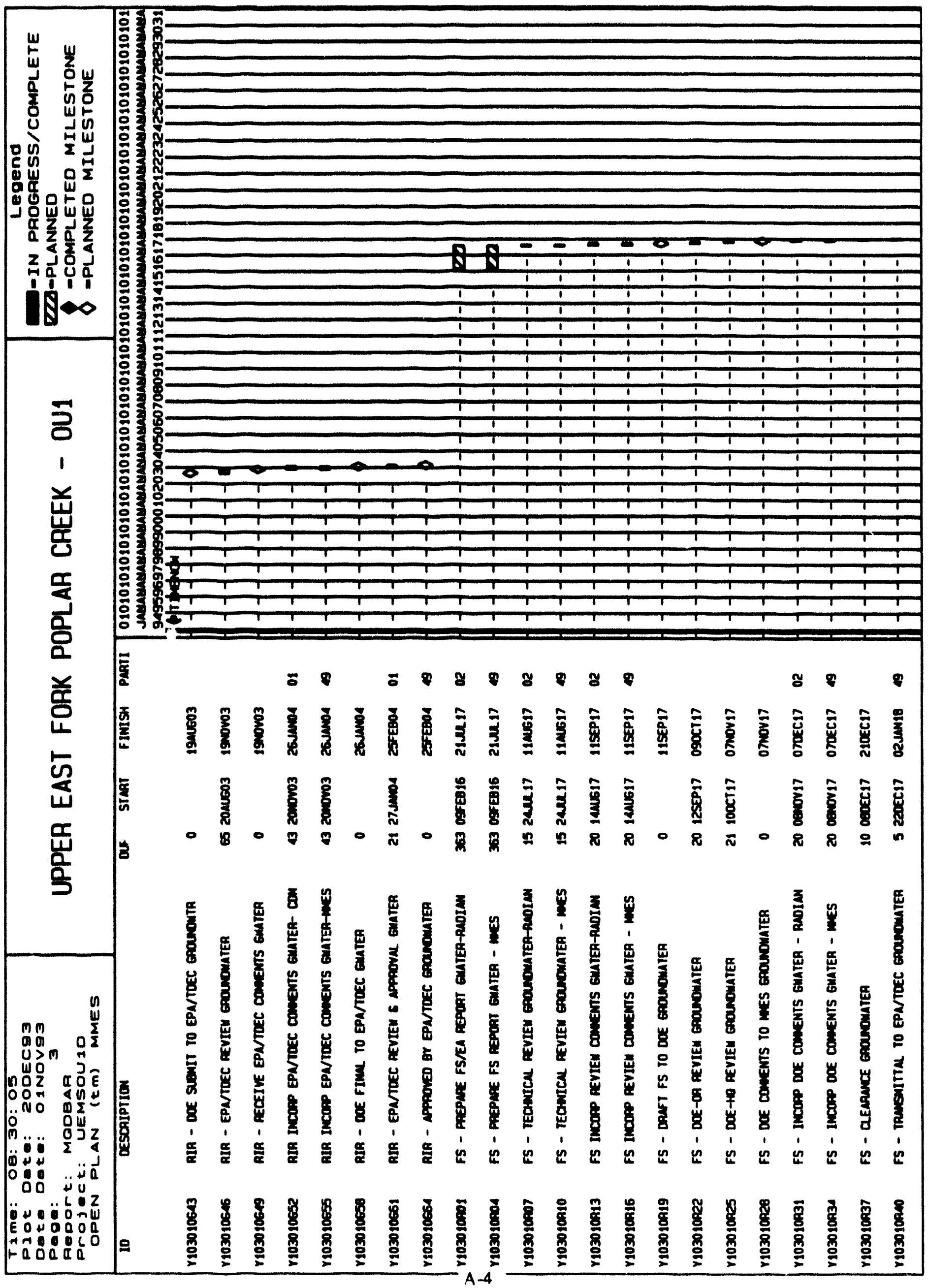




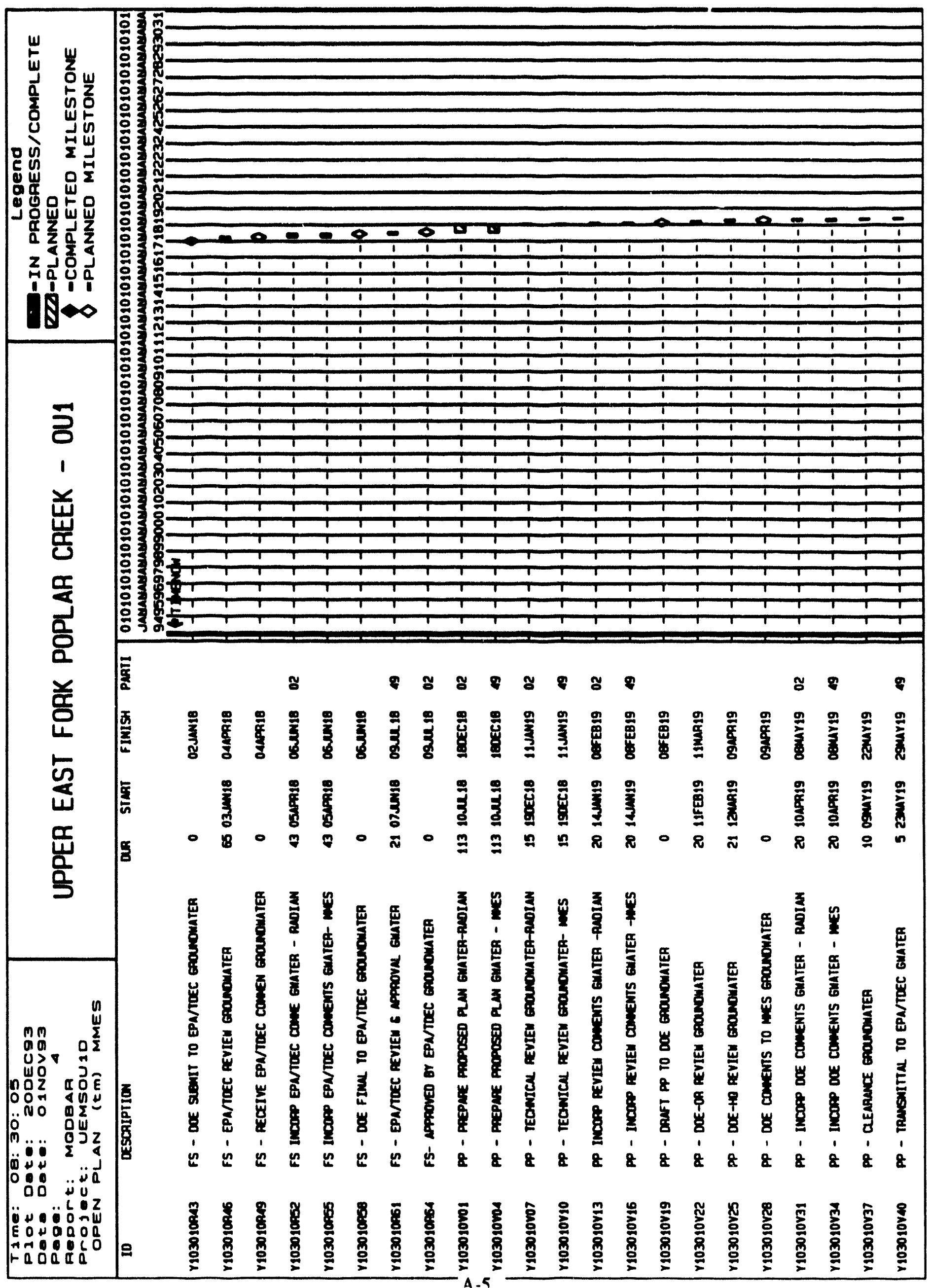




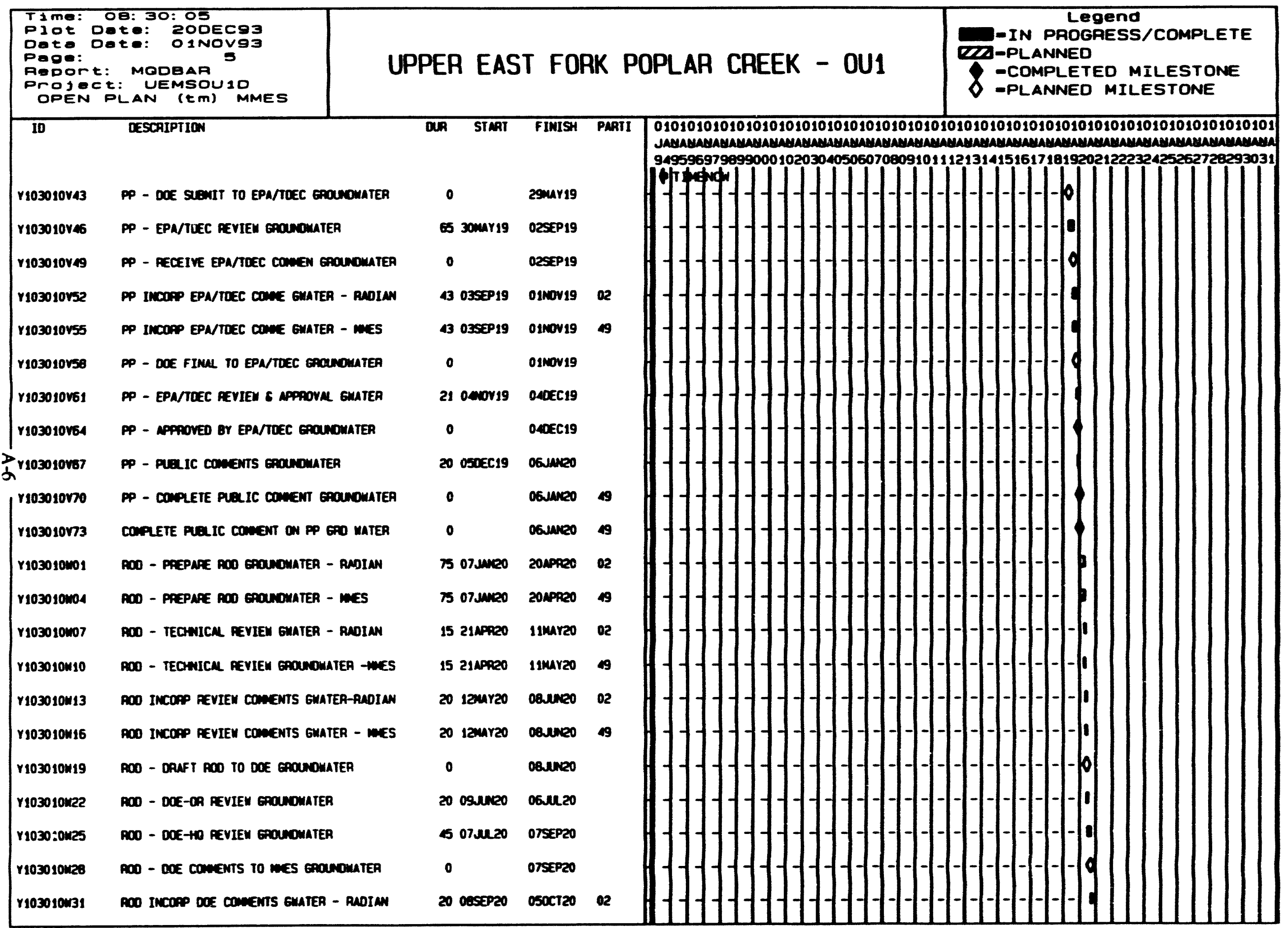




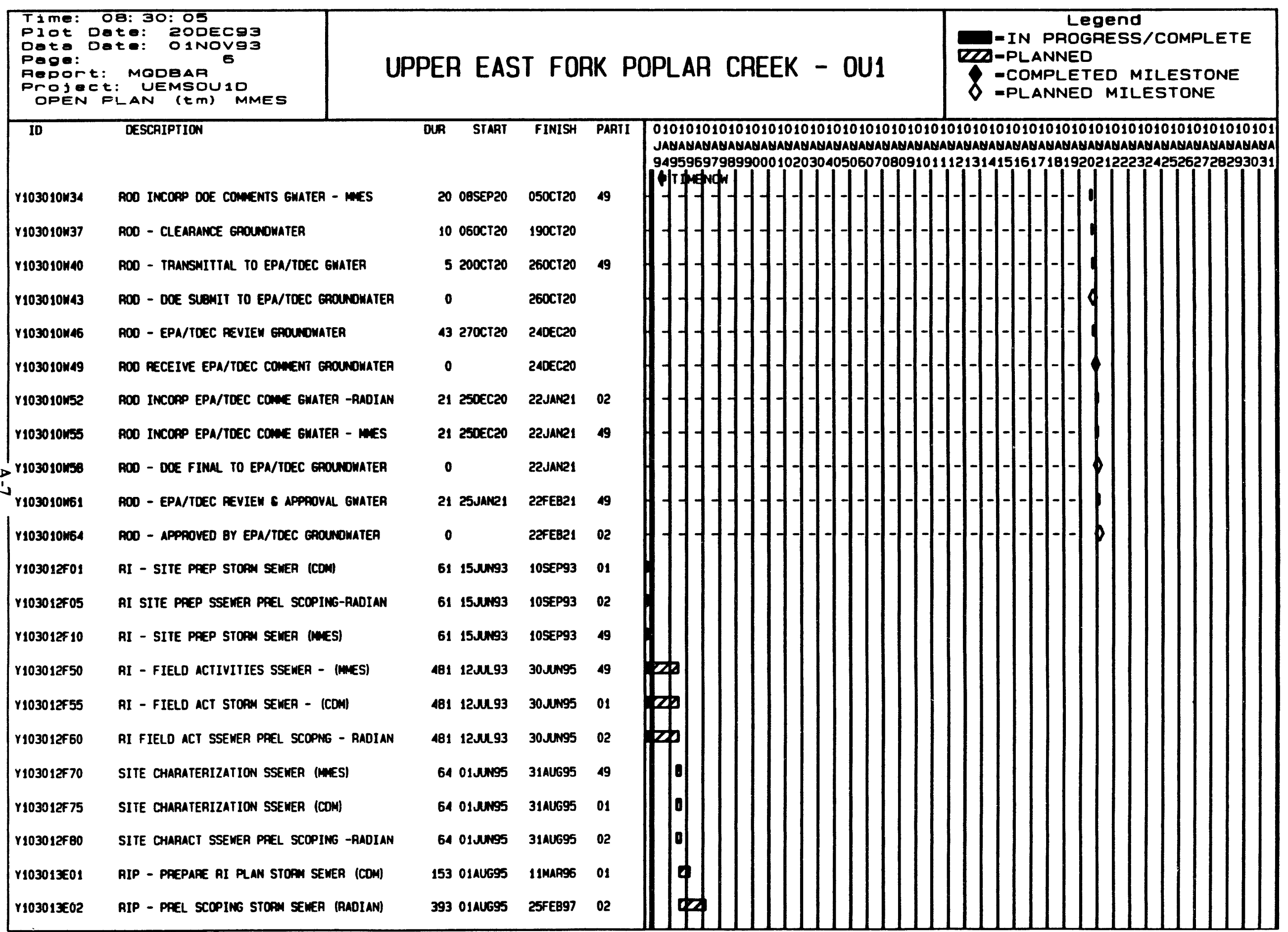




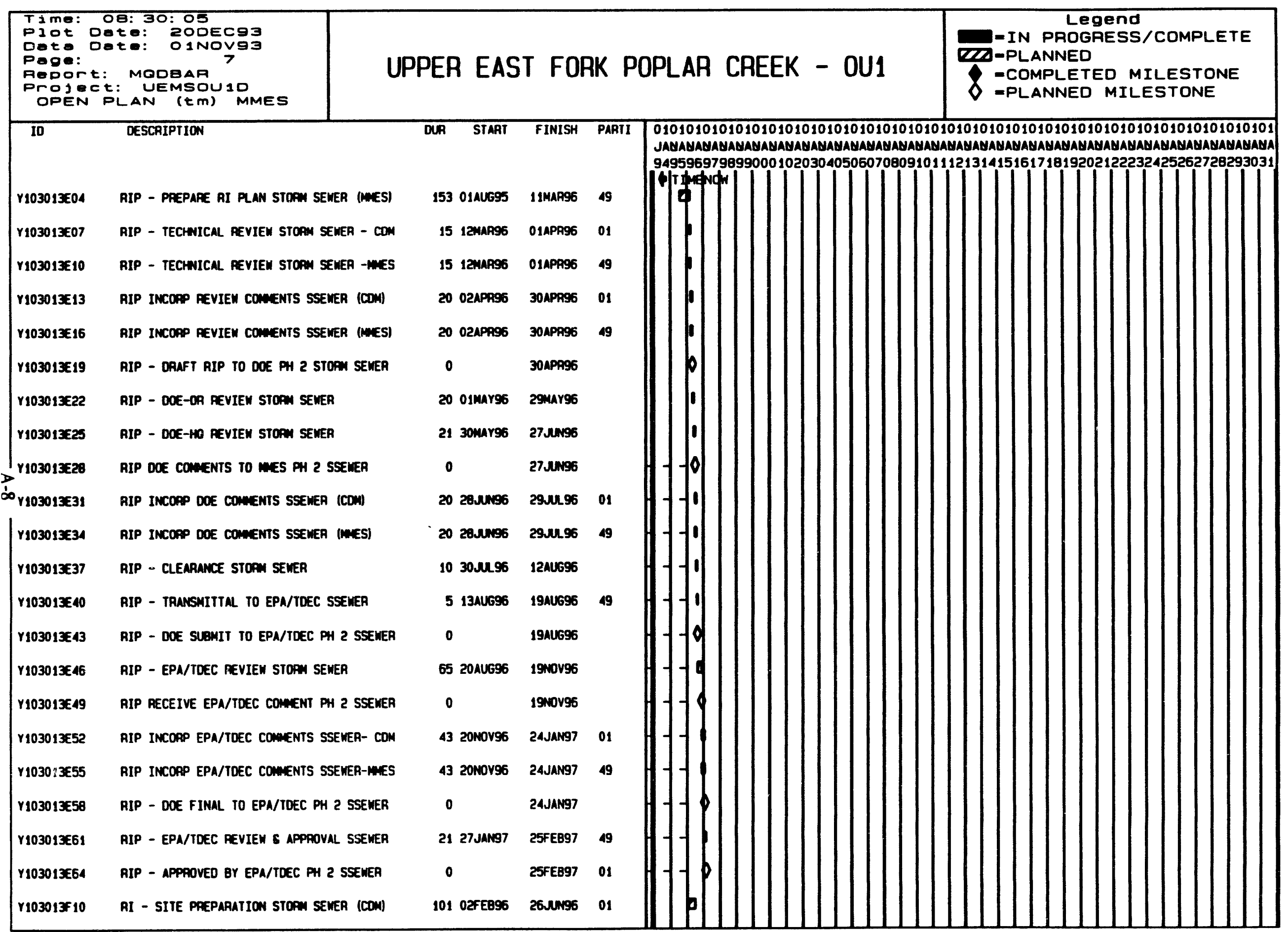




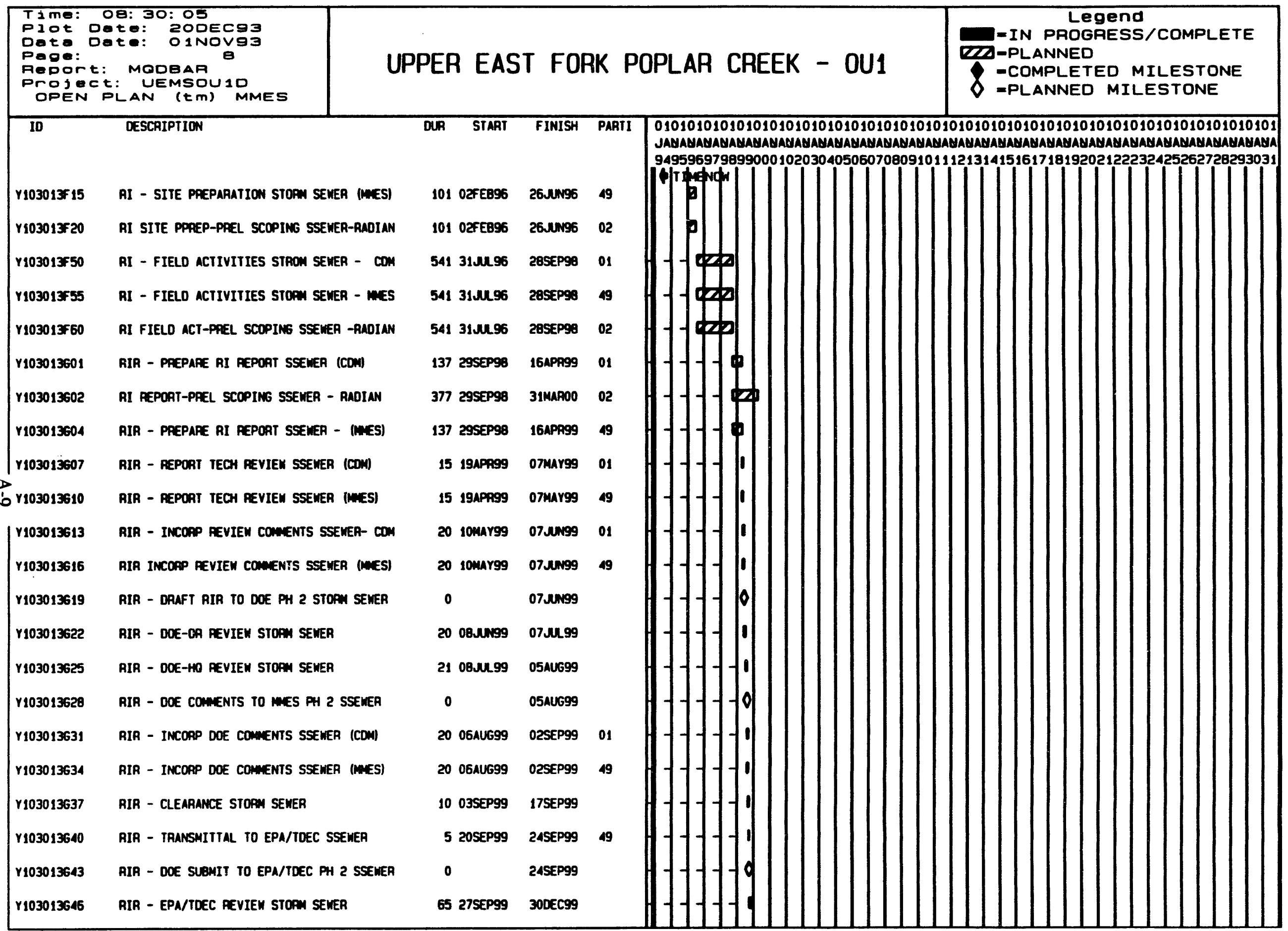




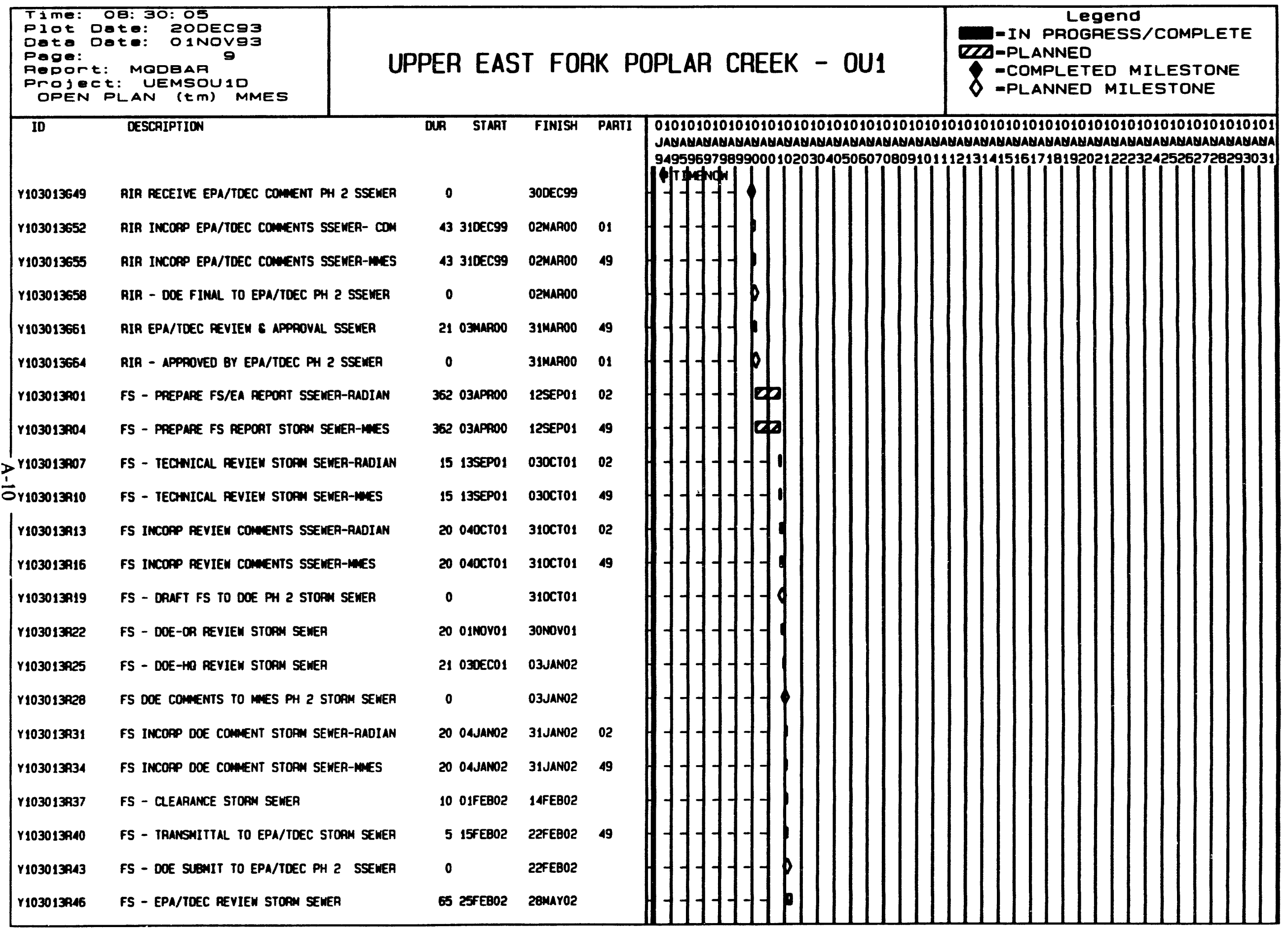




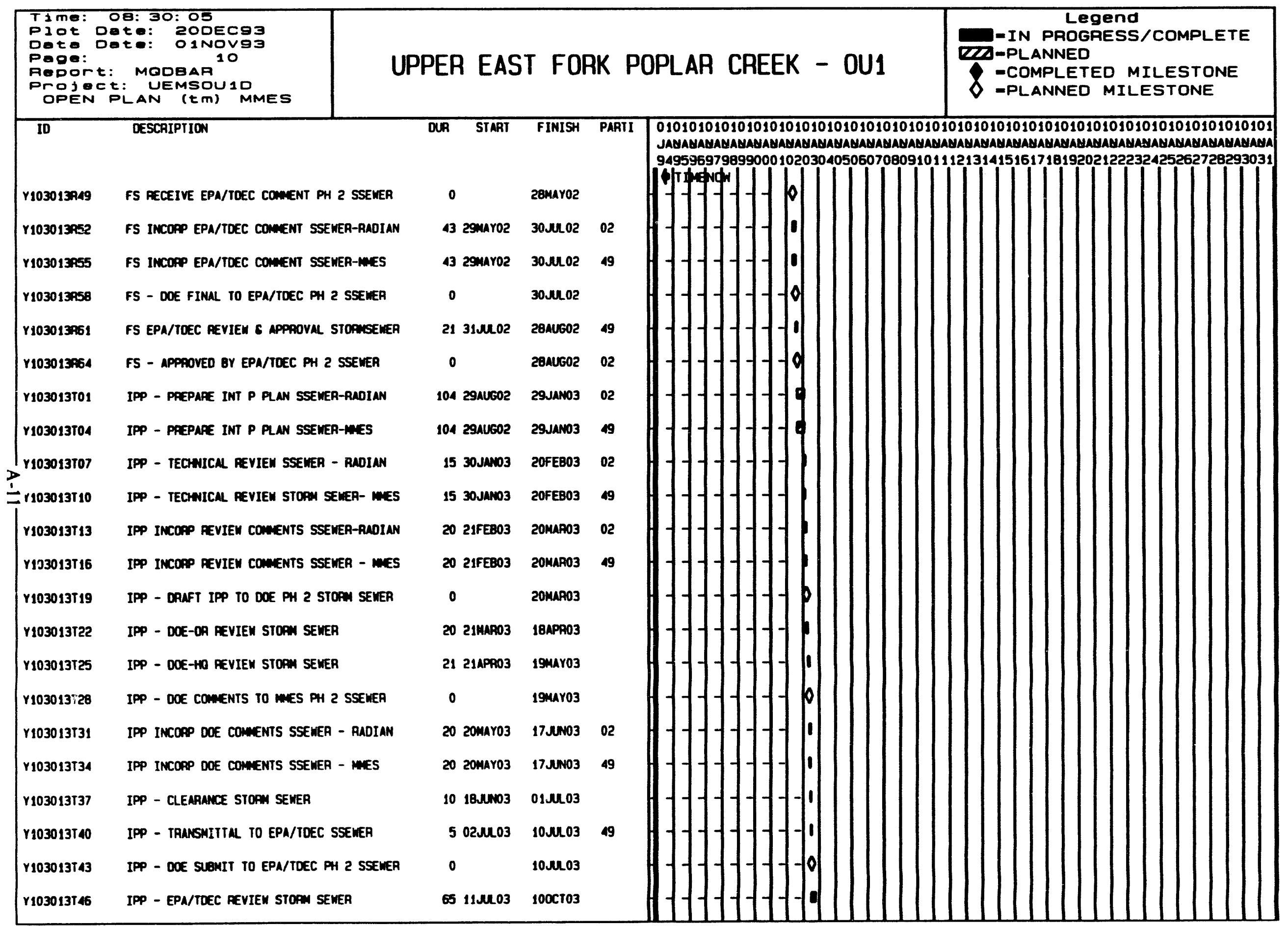




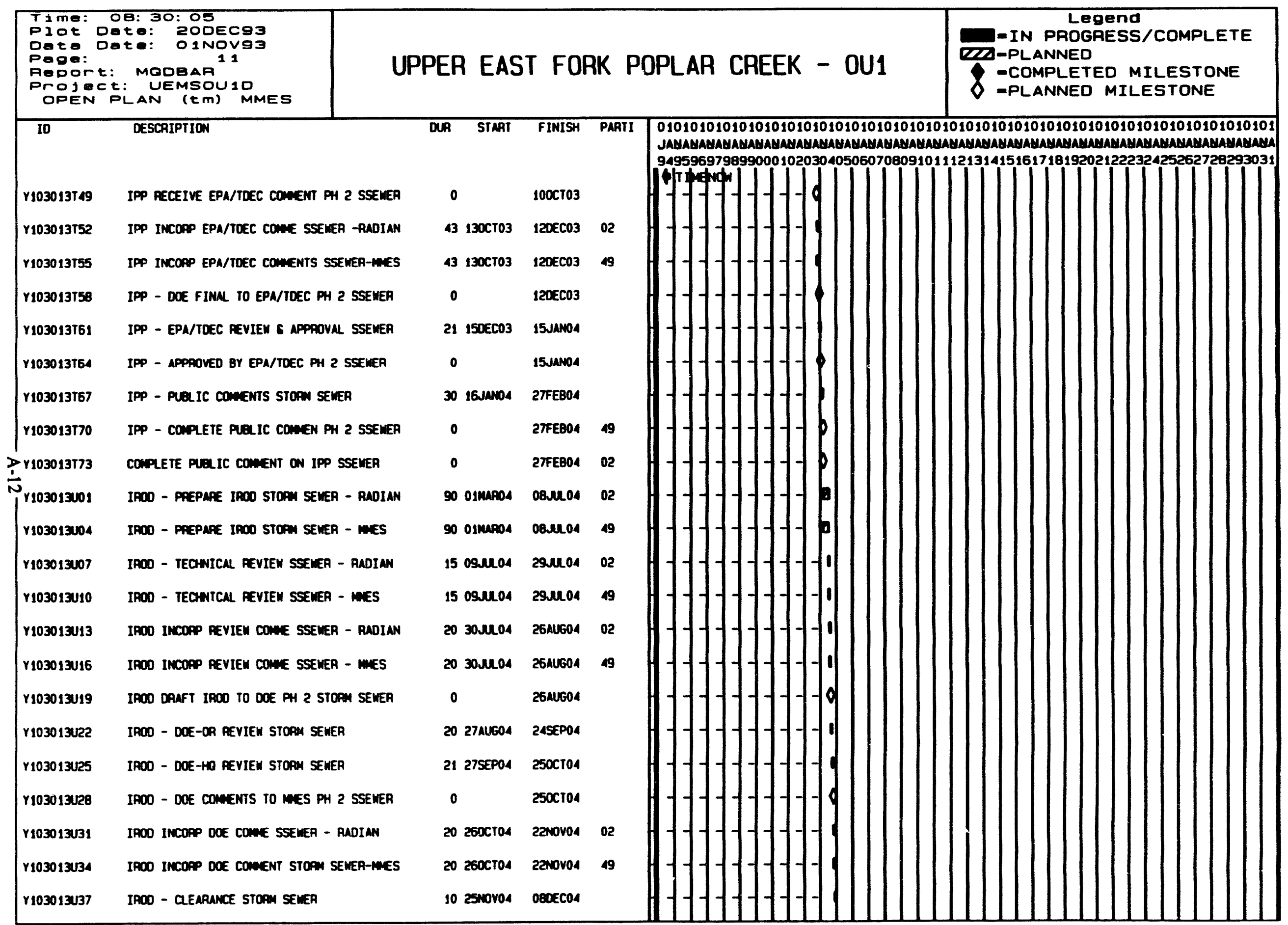




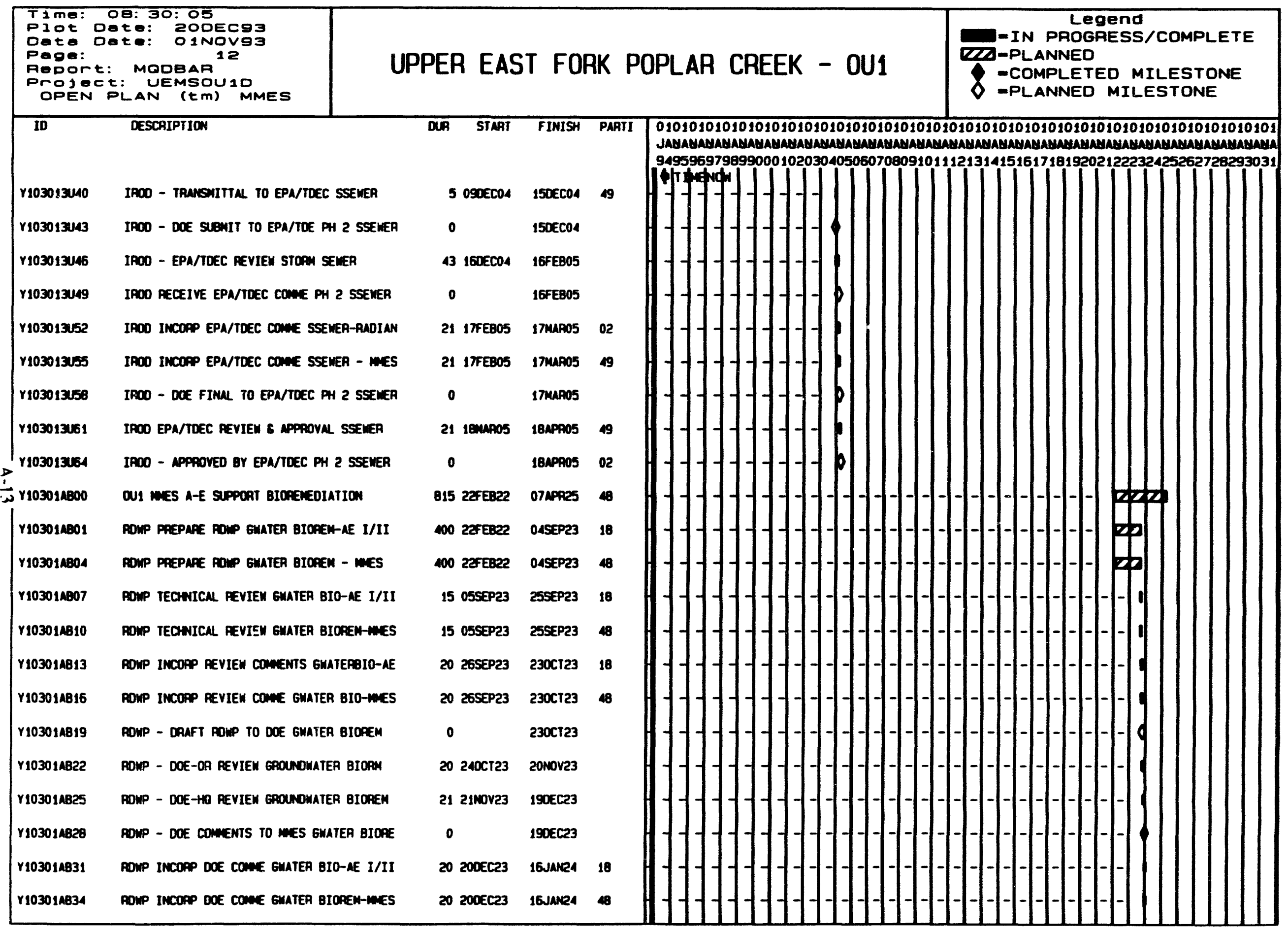




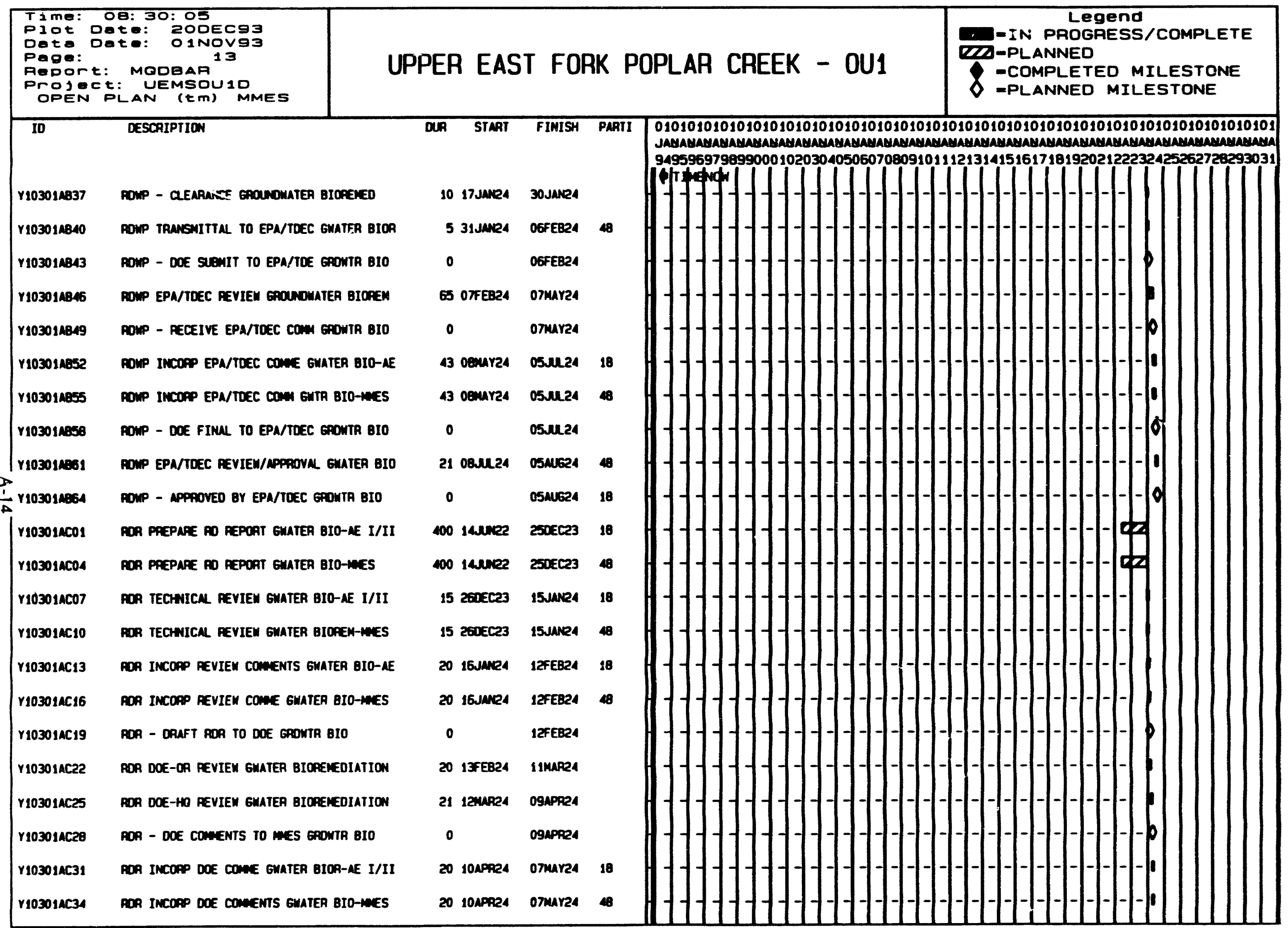




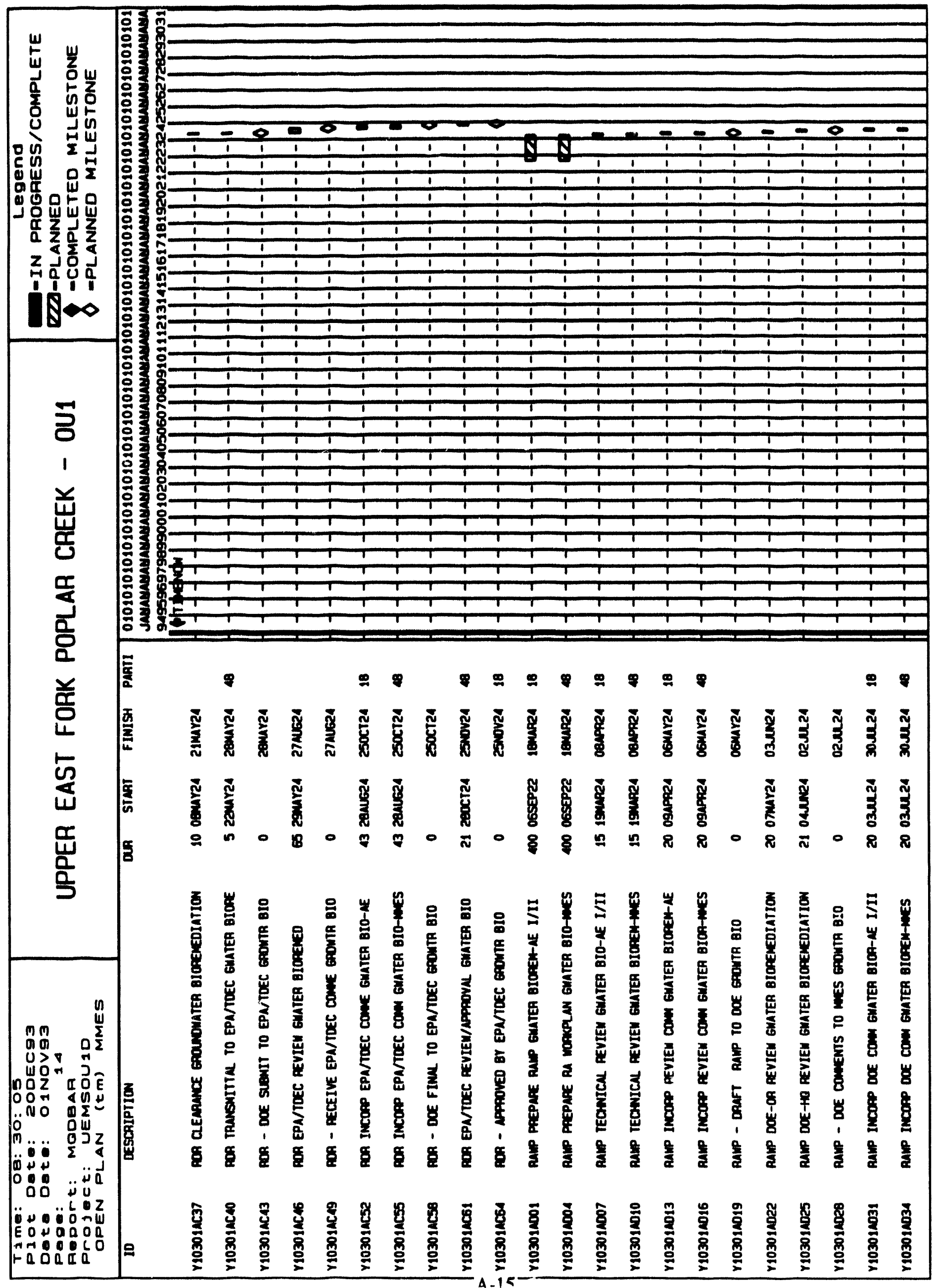




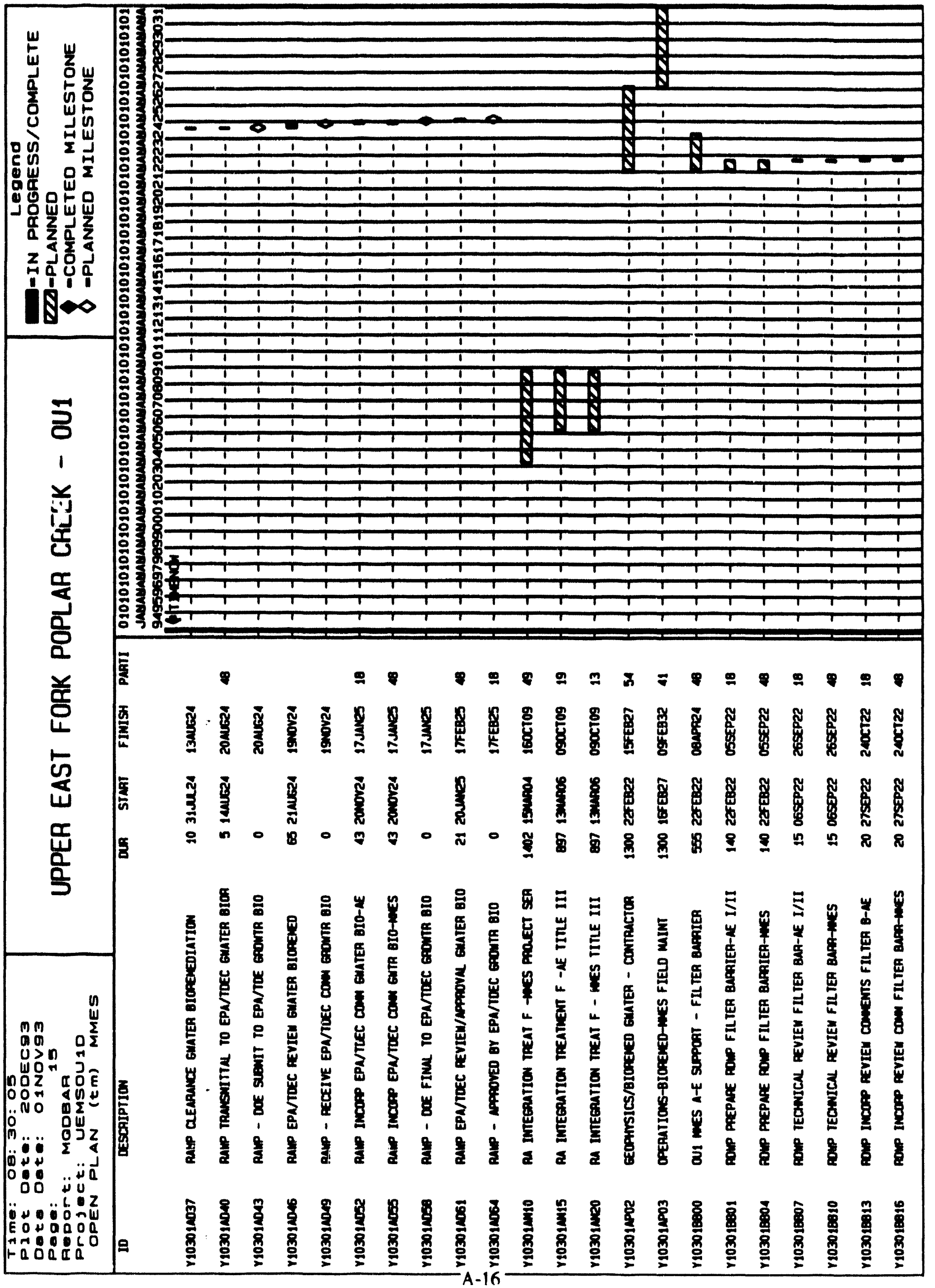




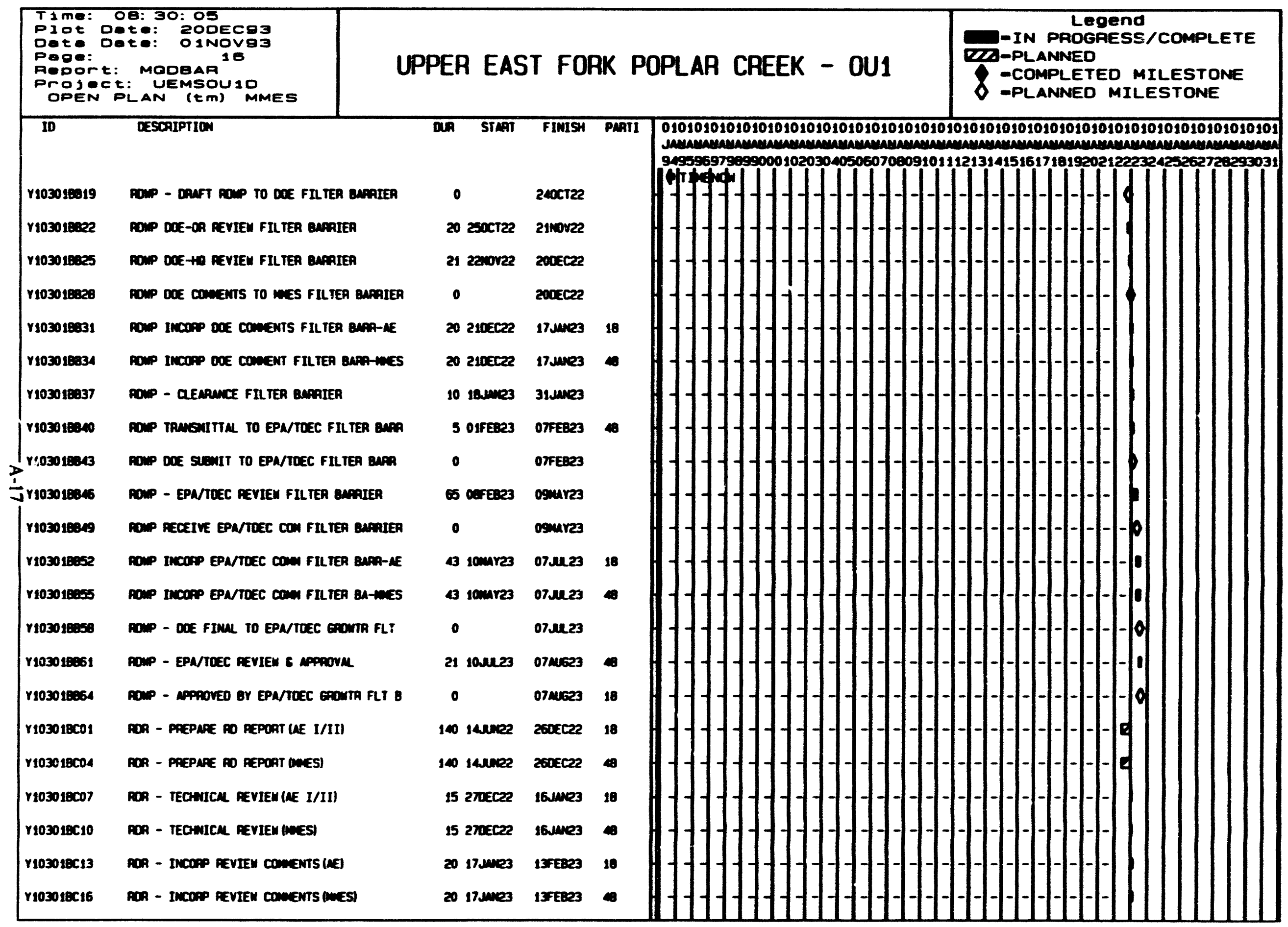




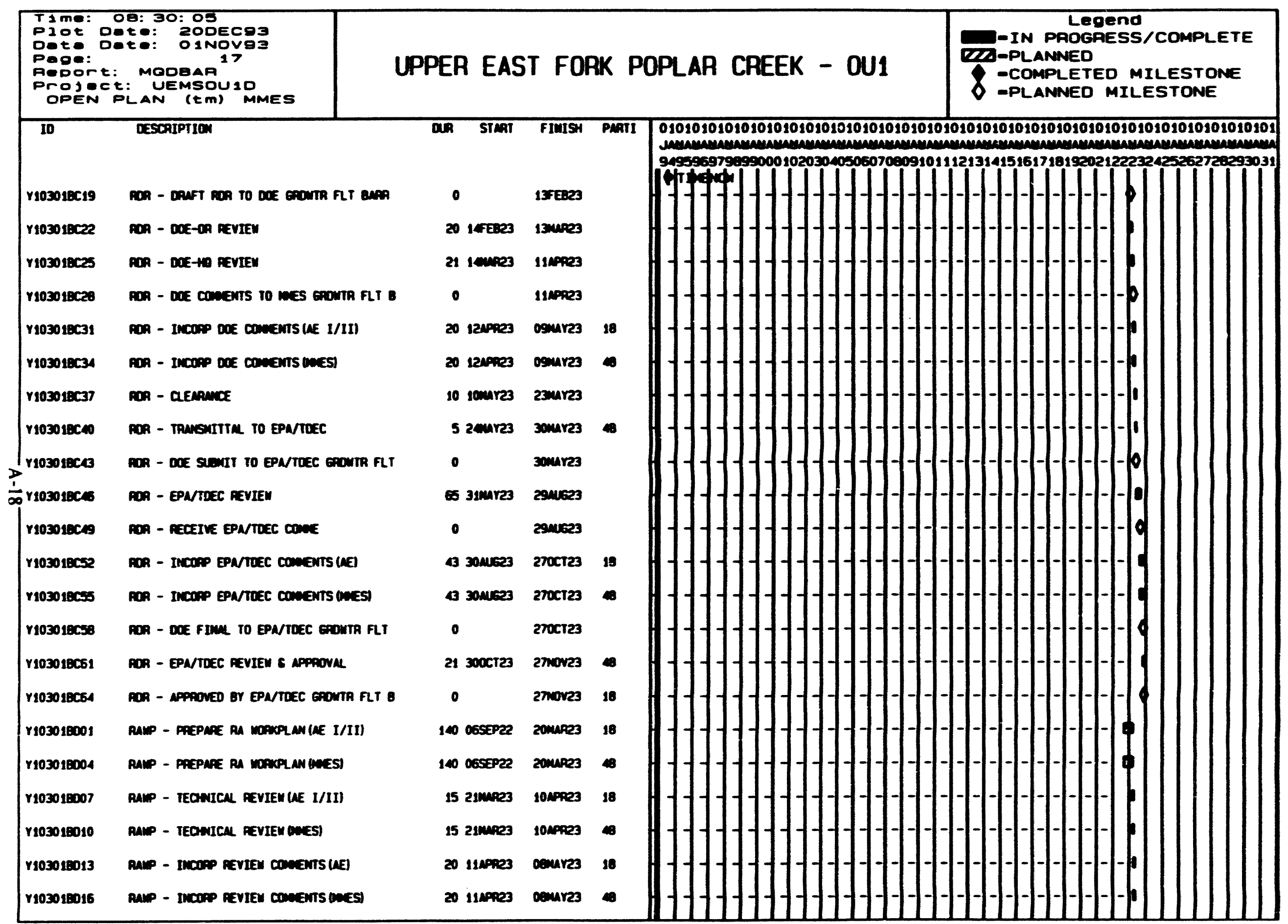




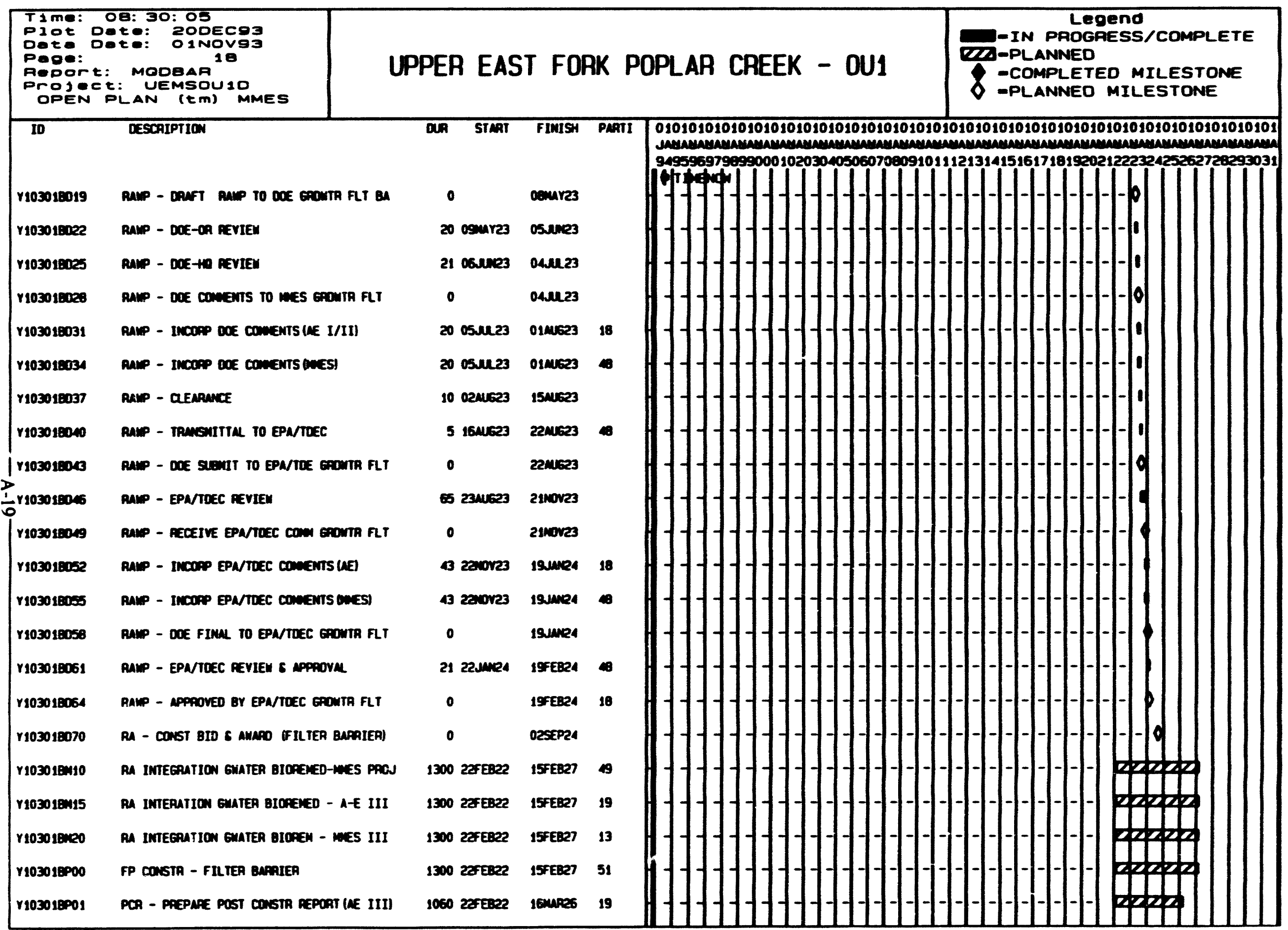




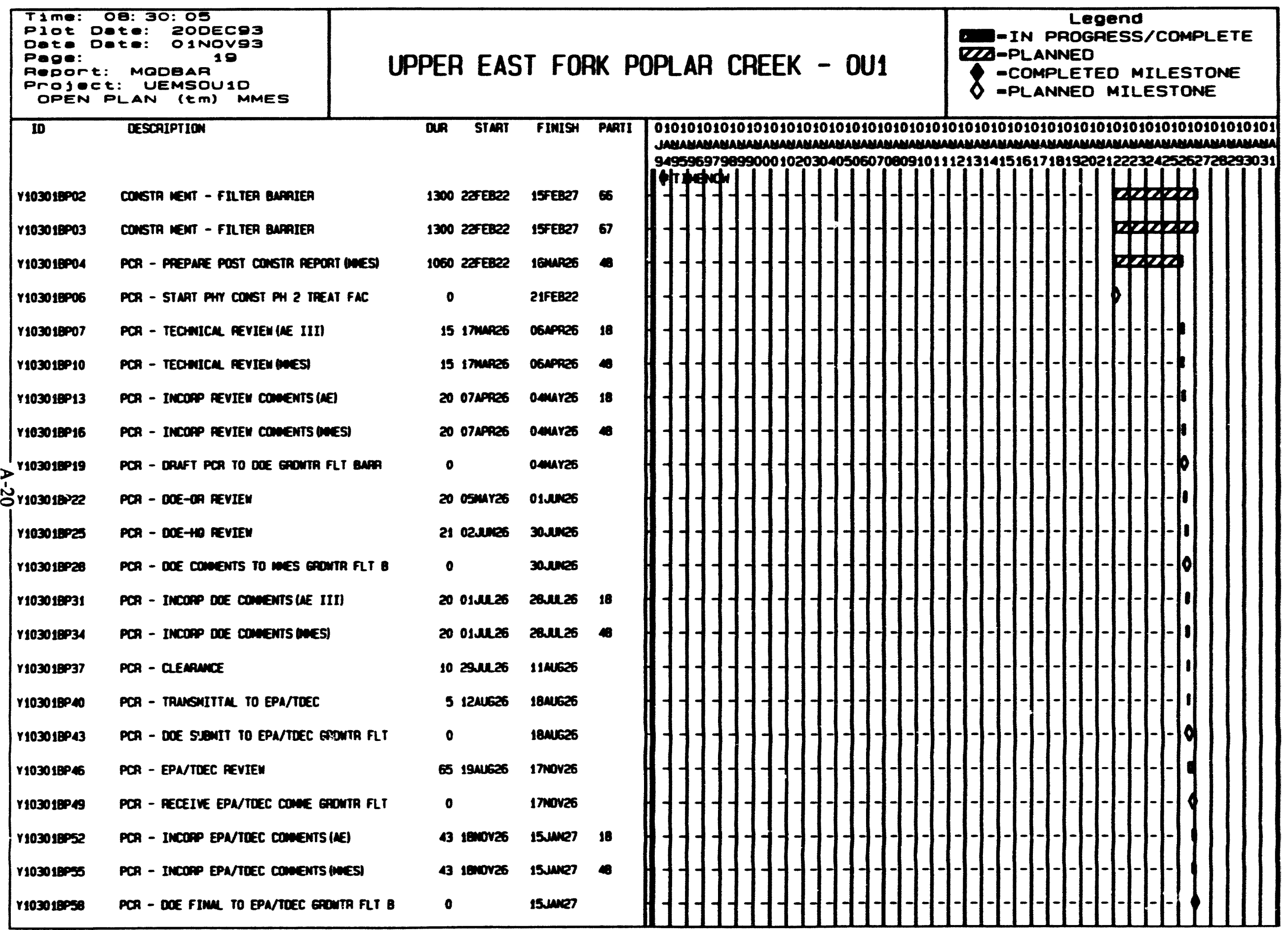




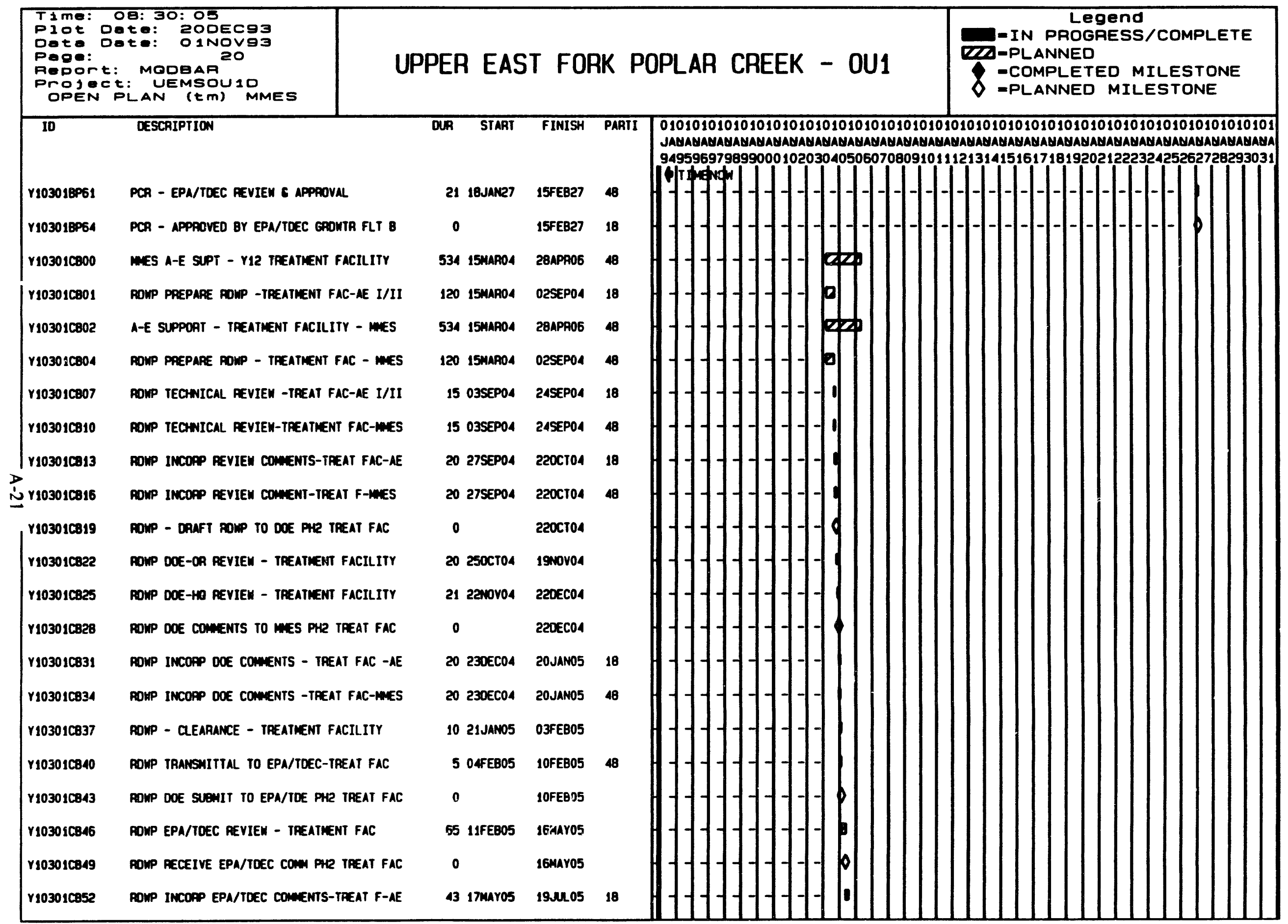




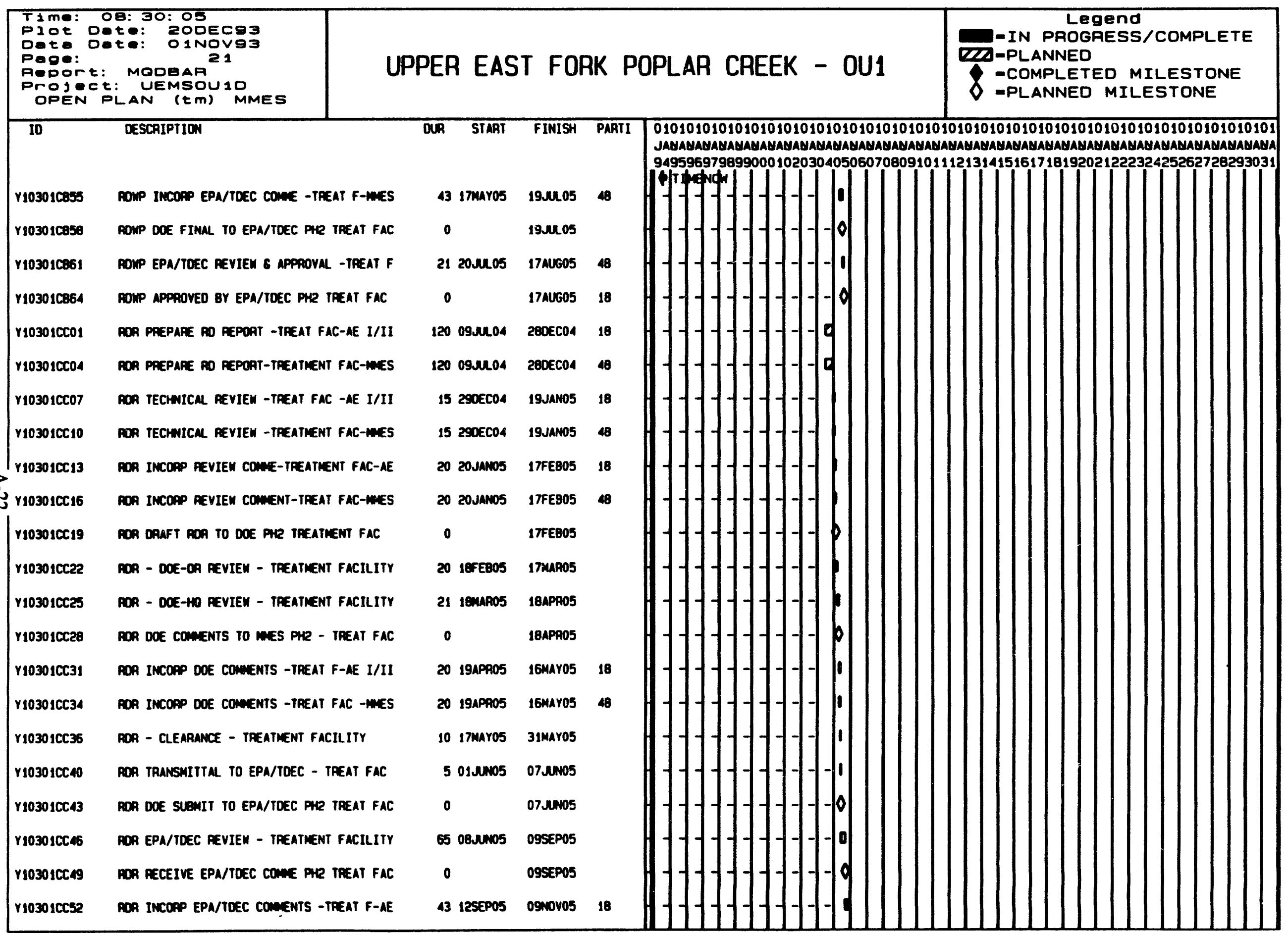




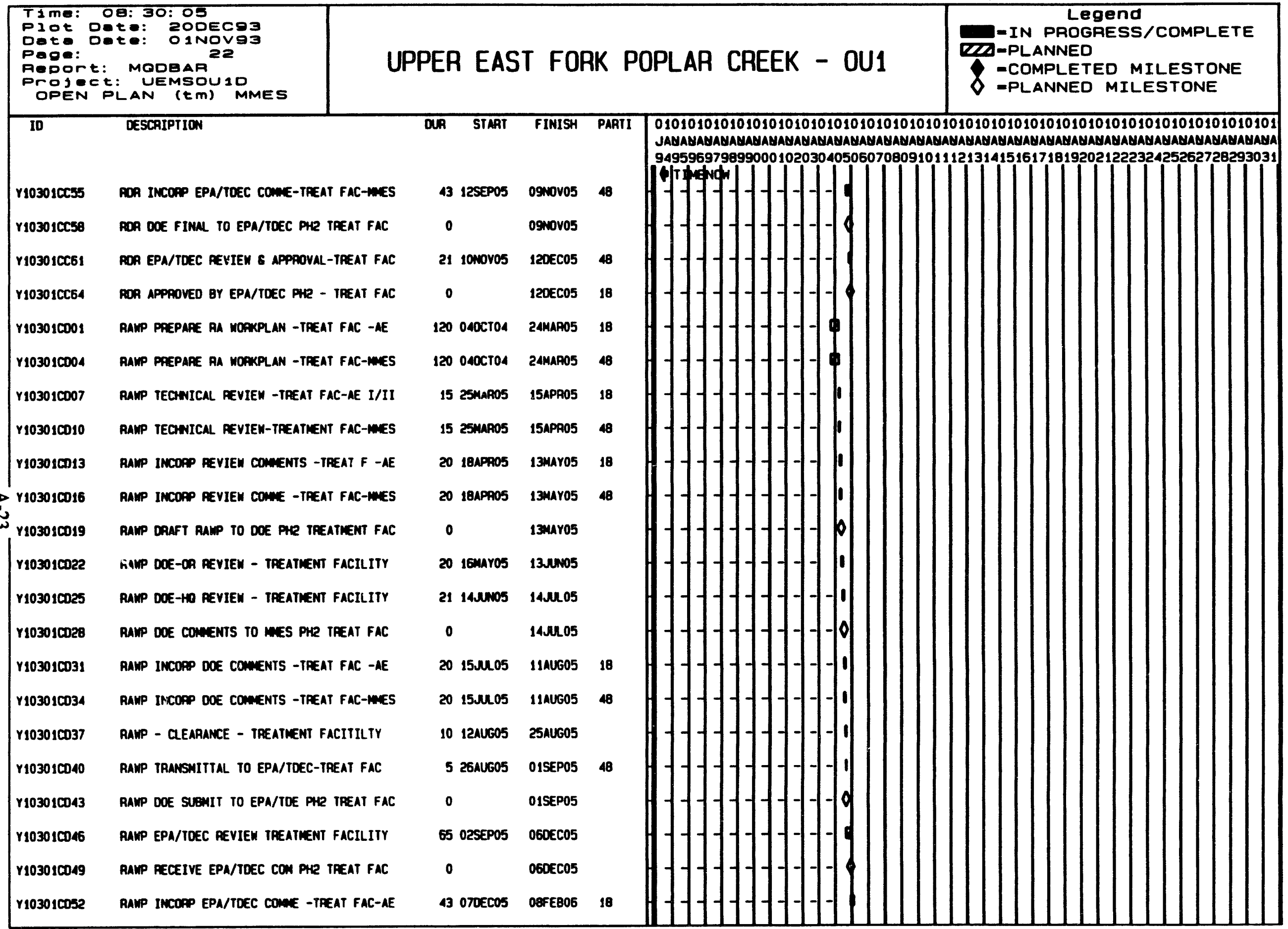




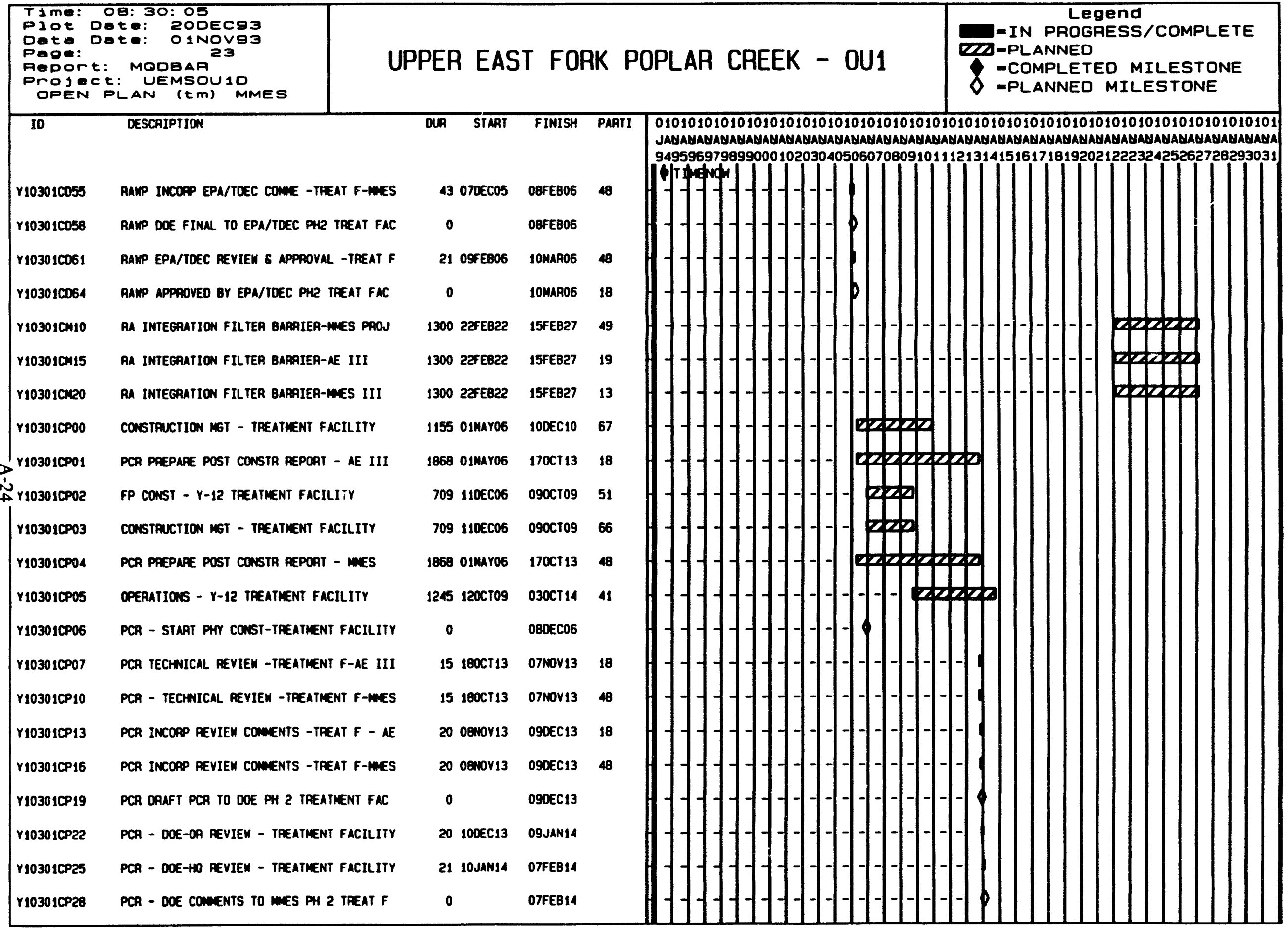




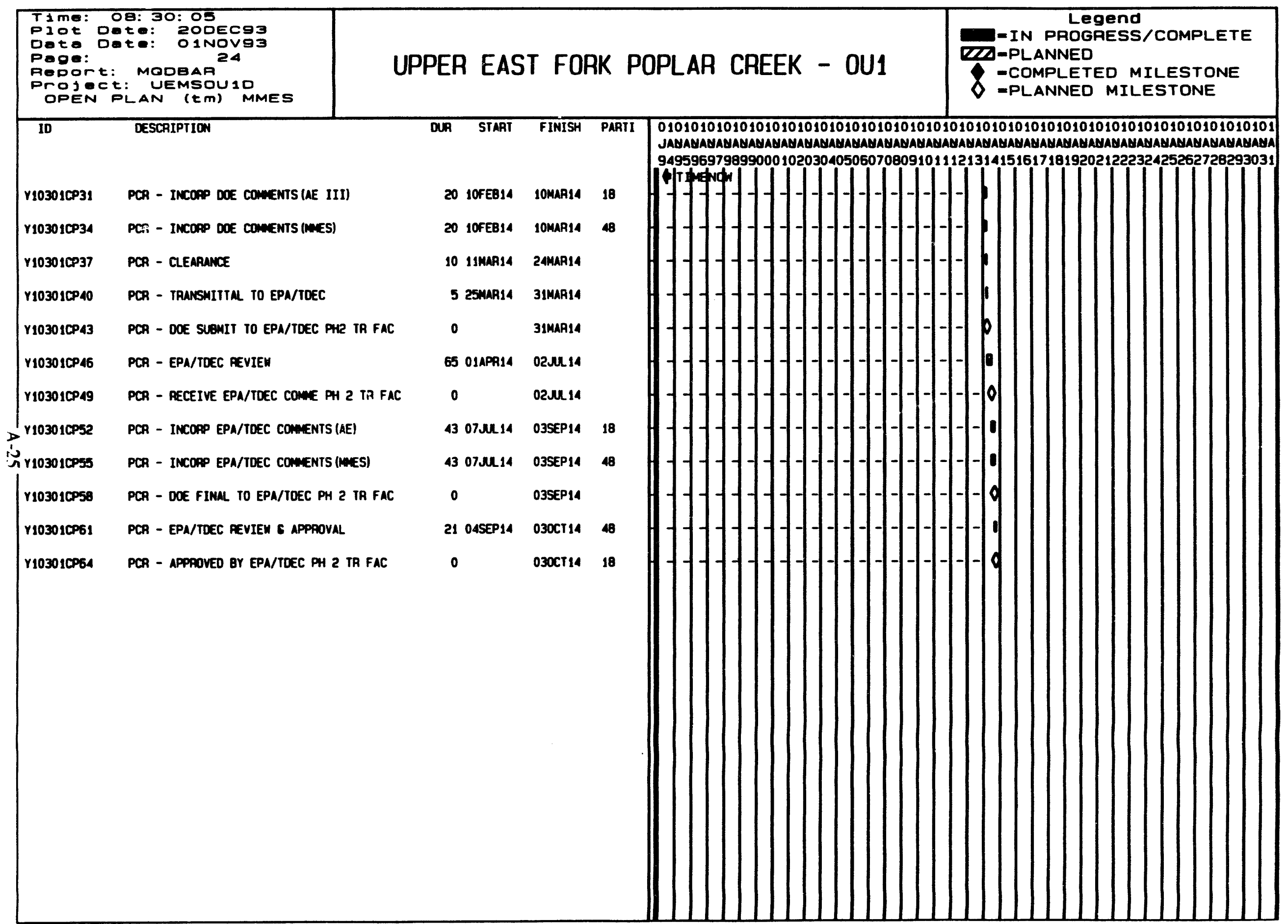




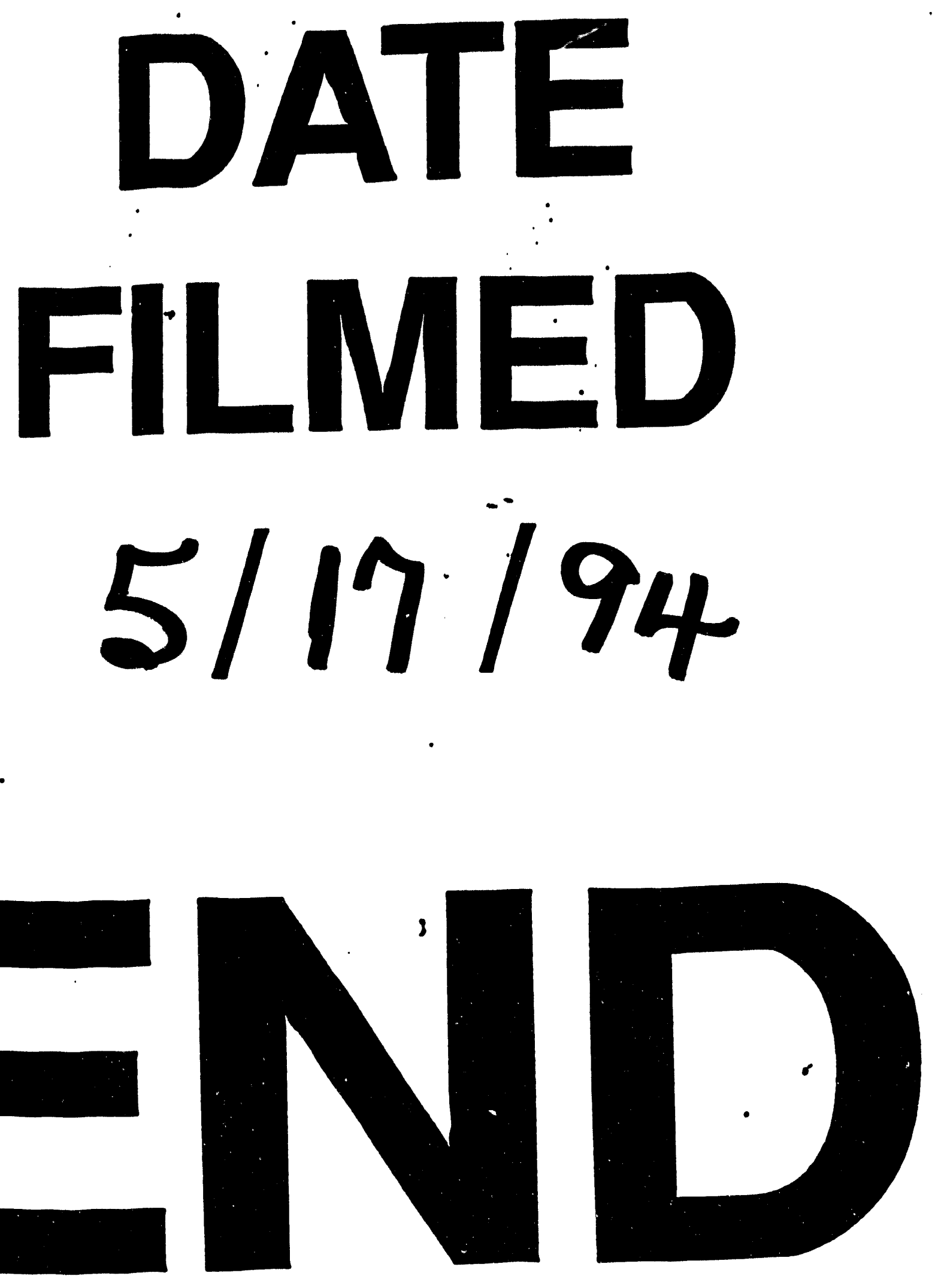


